Laura Ximena Hernández Vélez

\title{
Avaliação da contribuição do Plano de Ordenamento Territorial na construção de resiliência e sustentabilidade urbana na cidade de Bogotá
}

\section{Dissertação de Mestrado}

Dissertação apresentada ao Programa de Pós-graduação em Engenharia Urbana e Ambiental da PUC-Rio como requisito parcial para obtenção do grau de Mestre em Engenharia Urbana e Ambiental.

Orientadora: Profa . Maria Fernanda Rodrigues Campos Lemos 


\section{Laura Ximena Hernández Vélez}

\section{Avaliação da contribuição do Plano de Ordenamento Territorial na construção de resiliência e sustentabilidade urbana na cidade de Bogotá}

Dissertação apresentada como requisito parcial para obtenção do grau de Mestre em Engenharia Urbana e Ambiental em Engenharia Urbana e Ambiental da PUC-Rio. Aprovada pela Comissão Examinadora abaixo assinada.

Profa. Maria Fernanda Campos Lemos.

Orientadora

Departamento de Arquitetura e Urbanismo - PUC-Rio

Profa. Raquel Hemerly Tardin Coelho

UFRJ

Prof. Rodrigo Rinaldi de Mattos

Departamento de Arquitetura e Urbanismo - PUC-Rio

Prof. Márcio da Silveira Carvalho

Coordenador Setorial do Centro

Técnico Científico - PUC-Rio

Rio de Janeiro, 19 de abril de 2017 
Todos os direitos reservados. É proibida a reprodução total ou parcial do trabalho sem a autorização da universidade, do autor e do orientador.

\section{Laura Ximena Hernandez Velez}

Graduou-se em Engenharia Ambiental e Sanitária pela Universidade Pontifícia Bolivariana - UPB, em 2006. Especialista em Consultoria Ambiental.

Ficha Catalográfica

Hernández Vélez, Laura Ximena

Avaliação da contribuição do Plano de Ordenamento Territorial na construção de resiliência e sustentabilidade urbana na cidade de Bogotá / Laura Ximena Hernández Vélez ; orientadora: Maria Fernanda Rodrigues Campos Lemos. 2017.

$118 \mathrm{f.} ; 30 \mathrm{~cm}$

Dissertação (mestrado)-Pontifícia Universidade Católica do Rio de Janeiro, Departamento de Engenharia Civil, Programa de Pós-Graduação em Engenharia Urbana e Ambiental, 2017.

Inclui bibliografia

1. Engenharia Civil - Teses. 2. Engenharia Urbana e Ambiental - Teses. 3. Resiliência. 4. Planejamento urbano. 5. Mudanças climáticas. 6. Política de ordenamento. I. Campos, Maria Fernanda Rodrigues Campos Lemos. II. Pontifícia Universidade Católica do Rio de Janeiro. Programa de PósGraduação em Engenharia Urbana e Ambiental. III. Título. 


\section{Agradecimentos}

Agradeço aos meus pais Martin Hernandez (in memorian) e Patrícia Velez.

Agradeço ao meu amor Jose Luís Mansilla pelo apoio e compreensão da minha ausência durante as aulas do Mestrado.

Agradeço as minhas amigas Yaima Cires, Laura Pissani, Dayana Burbano e Sirley Melo pelos momentos de descontração que tornaram a minha estadia no Rio mais agradável e emocionante.

Agradeço a minha orientadora Maria Fernanda que apesar do pouco tempo, encontrou um espaço para nortear a minha pesquisa. 


\section{Resumo}

Velez, Laura Ximena Hernandez; Lemos, Maria Fernanda Campos (Orientadora). Avaliação da contribuição do Plano de Ordenamento Territorial na construção de resiliência e sustentabilidade urbana na Cidade de Bogotá. Rio de Janeiro, 2017. 118p. Dissertação de Mestrado. Departamento de Engenharia Civil e Ambiental, Pontifícia Universidade Católica do Rio de Janeiro.

No último século, o mundo tornou-se um "mundo urbano" e as cidades passaram concentrar um maior número de pessoas (com mais de 50\% da população mundial residindo nelas). Atualmente, os desafios socioambientais que as cidades enfrentam impulsionam novas alternativas para o planejamento urbano atual. Nessas condições é esperado que as cidades sejam foco de mudanças e encontrem novas possibilidades na área do planejamento de cidades levando em conta os aspectos de resiliência e sustentabilidade durante a elaboração da Política Municipal. Essa pesquisa trata-se de um estudo de caso realizado na Cidade da Bogotá, capital do país da Colômbia, que avaliou o Plano de Ordenamento Territorial - POT (como instrumento de planejamento) e o comprometimento do mesmo, com a construção de resiliência em uma cidade altamente susceptível à mudança climática, com muitos desafios de dinâmicas populacionais, espalhamento ao longo de áreas rurais, problemas de mobilidade e deficiência da infraestrutura, cada um com sua necessidade de atendimento no planejamento em questão. O objetivo é conhecer qualitativamente, se o Plano tem orientação e pode contribuir na construção de resiliência urbana. A metodologia usada foi desenvolvida na pesquisa prévia de Lemos (2010) e envolve categorias de sustentabilidade e resiliência, com os possíveis efeitos de ações descritas no Plano. Após a aplicação metodológica e revisão do POT, os resultados demonstraram que o Plano está orientado para a resiliência, porém a sua contribuição é frágil na definição ações conjuntas em diferentes níveis do poder político.

\section{Palavras chave}

Planejamento urbano; resiliência; mudança climática; política de ordenamento. 


\section{Extended Abstract}

Velez, Laura Ximena Hernandez; Lemos, Maria Fernanda Campos (Advisor). Evaluation of the contribution of the Master Plan in the construction of urban resilience and sustainability in the city of Bogota. Rio de Janeiro, 2017. 118p. Dissertação de Mestrado. Departamento de Engenharia Civil e Ambiental, Pontifícia Universidade Católica do Rio de Janeiro.

The worldwide population rises in an accelerated way, especially in the regions with low economical and institutional capacity to guarantee the organized urban development, which allow the mixture of land use, the preservation of nature within the city and maintain the health and well-being of the citizens, while takes economic prosperity to the country. The population growth and the worldwide production are happening with models and Technologies that are unsustainable. This picture has multiplied the pressure over the environment, causing a climate change with consequences still unpredictable (ONU HABITAT, 2009).

The climate change sets up new challengers mainly to governments and planners and designers that have to face up the uncertain of the future events. In the middle of this real situation and according to was mentioned by URWIN \& JORDAN, 2007 now is more evident that new policies in climate and nonclimate sectors will need to be designed in ways which facilitate rather than hinder adaptive decision.

Against this backdrop arises a vision of planning from the perspective of resilience, term that is defined in ecology, persistence of relationships within a system and is a measure of the ability of these systems to absorb changes of state variables, driving variables and parameters and still persist (Holling, 1973). This concept is complemented later by Walker (2004), including also the capacity of the system to reorganize itself in the middle of changes, in order to maintain the same function, structure, identity and feedback process.

As a result of the inclusion of this concept in the urban planning, Resilience has become in a powerful notion that exceeds natural and social sciences used as a basis for decision-making in studies of the complex interactions between society, 
land use management and policy according to Wilson (2012). Resilience capacity also requires building an adaptable social infrastructure to assure meaningful participation and achieve equity in the face of socio-economic change and disturbance, and meaningful participation by stakeholders in planning and policy decisions just like comment Ahern (2011). Participation and involvement from multiple stakeholders are important pillars to develop a more inclusive planning.

The Territorial Planning Plans (TTP or POT by its Spanish acronym), proposed by Colombian laws, as mechanisms of planning and organization of the cities, they are defined by Article 9 from Law 388 of 1997 like a whole of objectives, orientations, policies, strategies, goals, programs, actions and rules adopted to orient and manage the physical development of territory and the land use (COLOMBIA, 1997). It is precisely the POT of Bogota (the biggest city of Colombia and the capital of the country) the object of study of this research, as well as its commitment with the construction of a more resilient and sustainable Bogotá.

In order to get that evaluation of this policy, the methodology used in this research developed by Lemos, (2010), in her own search for a qualitative tool that allows to evaluate the level of contribution of municipal planning in adaptation and enlargement of urban resilience (for her research Rio de Janeiro's Master Plan), defined categories of sustainability that were studied in the actions raised in the articles of the TPP, trying to find how this actions can have the potential or not to mitigate, anticipate, reduce exposure, reduce sensitivity or enhance adaptive capacity in front of extreme climate events.

The premises of the methodology of evaluation include the revision of a specific diagnosis of vulnerability, based on a climatic scenery of a specific area, the adaptation can be easier. The relationship between sustainability and resilience is closed, in order to link the principles of planning for urban sustainability with actions of contributions to the resilience of the city. The adaptive measures have to be product of a proactive planning considering the future risk, with the capacity to look into the future, capacity intrinsic to planning. The construction of policies with the principal of resilience is a compelling need. Right now the politics is changing the discourse of urban planning, including the concerns of Climate Change's existence and how this can affect the stability of the agglomerations and its capacity

to generate disturbs. 
The categories of sustainability represent the study of mechanisms and strategies to use in land use planning to build resilience and sustainability in the urban settlements. In the creation and execution of Master Plans for urban development, must be include, according to Ahern (2011), some of the following strategies: Multifunctionality, redundancy and modularization, diversity, multiscale connectivity and adaptive planning and design. This concepts must to influence the installed actions inside the plan.

On the other hand the methodology defined 7 categories and 26 subcategories (plus one more category including for the author) shown in the table 1.

Table 1. Categories of sustainability

\begin{tabular}{|c|c|}
\hline Sustainability categories & Sub-categories of sustainability \\
\hline \multirow{3}{*}{$\begin{array}{l}\text { Integration and social, physical- } \\
\text { territorial justice }\end{array}$} & Promotion of the social Integration \\
\hline & Elimination of physical segregation \\
\hline & Fair distribution of the urban structure \\
\hline \multirow{5}{*}{$\begin{array}{l}\text { Adequacy of the relationship between } \\
\text { natural resources and the environment }\end{array}$} & Adequacy of consumption of resources \\
\hline & $\begin{array}{l}\text { Reduction of energy's demand and strategies of } \\
\text { local and clean energy }\end{array}$ \\
\hline & Reduction of emissions \\
\hline & Reduction of pollution \\
\hline & Reduction and improvement of solid waste \\
\hline \multirow{2}{*}{$\begin{array}{l}\text { Increase of durability and reduction of } \\
\text { idleness }\end{array}$} & Increase of durability \\
\hline & Reduction of idleness and obsolescence \\
\hline \multirow[t]{3}{*}{ Integrated approach } & Integrated approach between city and region \\
\hline & Integrated approach between city and nature \\
\hline & $\begin{array}{l}\text { Integrated approach between form, flows and } \\
\text { activities }\end{array}$ \\
\hline \multirow[t]{4}{*}{ Promotion of diversity } & Biodiversity \\
\hline & Economic diversity \\
\hline & Physical diversity \\
\hline & Social diversity \\
\hline
\end{tabular}




\begin{tabular}{|l|l|}
\hline Acknowledgment of limits & Acknowledgment of limits in the territory \\
\cline { 2 - 2 } & Acknowledgment of limits in density \\
\cline { 2 - 2 } & $\begin{array}{l}\text { Acknowledgment of limits of economic } \\
\text { development }\end{array}$ \\
\hline Sector themes to sustainability & Sustainable accessibility and mobility \\
\cline { 2 - 2 } & Access to adequate housing \\
\cline { 2 - 2 } & Personal health and environmental health \\
\cline { 2 - 2 } & Physical security \\
\cline { 2 - 2 } & Psychological security \\
\cline { 2 - 2 } & Fight poverty \\
\cline { 2 - 2 } & Urban agriculture* \\
\hline
\end{tabular}

Fonte: Adaptado Lemos, 2010, p. 168. Tradução do autor

*Category not included in the initial methodology

And specific mention has to be done in this definition of categories of sustainability, because during the documental revision, was clear the importance of including the Urban Agriculture as another sub-category due to the amount of benefits in the reduction of Urban heat islands, improvement of close environments and food security. This sub-category proved to be effective by increasing adaptive capacity and decreasing sensitivity, two important aspects of the resilience.

During the evolution of this research, it will be possible to find a relationship between the categories above and the expected results of the using of this categories as tools of action in the Master Plan.

\section{Methodological approach}

The mechanism of evaluation found a relationship between sustainability and resilience. Every article of the Plan that describe an action to be executed was evaluated initially in the Test matrix, the following matrix that it shows this mechanism with a specific article of the Master Plan as an example of the methodology used along the all Plan. 
Table 2. Test matrix (example with an article of the Master Plan)

\begin{tabular}{|l|l|l|l|c|l|}
\hline Article of Plan & \multicolumn{1}{|c|}{$\begin{array}{c}\text { Key } \\
\text { theme }\end{array}$} & $\begin{array}{c}\text { Sustainability } \\
\text { 'category }\end{array}$ & $\begin{array}{c}\text { Pro- } \\
\text { resilience }\end{array}$ & $\begin{array}{c}\text { Against } \\
\text { resilience }\end{array}$ & Comments \\
\hline $\begin{array}{l}\text { Art. 131 lit d. } \\
\text { Promotion and } \\
\text { diversification } \\
\text { of urban } \\
\text { orchards that } \\
\text { contribute to } \\
\text { decrease }\end{array}$ & $\begin{array}{l}\text { Sector themes } \\
\text { to } \\
\text { temperatures } \\
\text { sustainability } \\
\text { and maintain } \\
\text { food security } \\
\text { (Bogota, 2013) }\end{array}$ & $\begin{array}{l}\text { mitigation, } \\
\text { sensitivity }\end{array}$ & - & $\begin{array}{l}\text { The urban } \\
\text { expansion } \\
\text { has a } \\
\text { negative } \\
\text { impact on } \\
\text { loss of soil, } \\
\text { creating an } \\
\text { increasing of } \\
\text { food's price }\end{array}$ \\
\hline
\end{tabular}

Fonte: Adaptado Lemos, 2010, p. 173. Tradução do autor

The actions specified in the articles are related with at least one of the categories of sustainability described in Table 1. After that identified relationship, it mentioned the possible outcomes in terms of resilience; it's important define that the actions in the search of resilience include:

Mitigation: If the actions in the article can mitigate the climate change issues. Anticipation: If the actions in the article aren't reactionaries. Exposition: If the actions in the article can reduce the exposition and so the vulnerability. Sensitivity: If the actions in the article can reduce the sensitivity through direct intervention in the infrastructure. Adaptive capacity: If the actions extend the adaptive capacity mainly for social capital.

This sequences repeated with the articles of 2 of the 3 components of the Plan, allowed a qualitative evaluation of the possible tendencies of the document.

\section{Final results}

In the evaluation of the Bogota's Master Plan the proportions of results were: Sensitivity with $80 \%$ of the classified items. The exposition showed a $19 \%$ of the evaluated items, due to the amount of actions related to the subcategory integrated approach between nature and city. Mitigation maintain the $25 \%$ of the 
actions related and adaptive capacity include the $22 \%$ of the classified items. The diagnosis of the Master Plan include the studies of vulnerability and risk managment, also include in the objectives the restriction of thee urbanization in areas with high vulnerability of floods and landslides. With the methodological use of the orientation matrix it shows that the Master Plan has specific information about socio-climatic risks and vulnerabilities included on it. Its orientation is also described of an explicit way in the Title I Chapter VI. Climate change and management's risk, where the objectives are defined, including the application of the principle of caution and the necessary normativity to reduce the physical vulnerability. This reasons become the Master Plan of Bogota an oriented politics in the tackled of natural threats, looking for the reduction of social and climate vulnerabilities, with enhancement of urban resilience.

About the contribution of the master Plan, the greatest expected contribution is to the reduction of sensitivity, due to the high number of actions in the search of fear distribution of the urban structure and the tendency of the construction of and integrated approach between city and nature, that also reduce the exposition of the city to an extreme variations of the climate. The Master Plan defined the reduction of emissions in the Sub-Section 2 Guidelines of mitigation facing the climate change, as well as the requirement of establish a Policy of Ecourbanism and sustainable construction (adopted by Dec. 566 of 2014),with the goal of augment the rules and patterns in the construction, in order to reduce the loss of resources. It is possible to deduce that this policy is going to controlled the emissions of GHG which is positive to other actions that include construction like densification, construction of housing of quality to low income population or resettled population.

With all this analysis, the Master Plan of Bogota, shows a fragile contribution in the construction of resilience in the city. It is positive in defined the ecological structure as principal axis of order in the search of the reduction of pressure over it. At the same time defined the control over the urban expansion process that is happening on the periphery of the city. By including a lot of actions related to integration and social justice, the Master Plant shows a commitment of this tool of planning in the reduction of vulnerability of the normally excluded populations. The interdependence between local and regional scales can be a challenger because isn't clear how participation of actors, different institutional levels, 
commercial interest and dweller of different regions are going to be taking into account in the decision -making process, this situation also can be derived from the fact that the application of the methodology hadn't into account the "potentiators" factors that are de evaluators of management and execution from the law and aren't related to the issue of vulnerability.

The Master Plano of Bogota already includes the climate change concept in its framework, because of this, the contribution of this Plan in the structuration of new mechanisms of perform in front of climate change's uncertain it was already discussed and accepted as possible source of positive actions to the city. Finally the Plan include indicators to controlled constantly the evaluation of risks, in terms of mobility include the behavior of the road networks; also include indicators of environmental and functional quality from the built space and specific indicators for the sectorial policies.

There is a strong influence of concepts like, risks, vulnerability, climate change, resilience, adaptive capacity, sensitivity and mitigation in the Master Plan of Bogota, however the main concerns have to be how the multiple scales (municipal and regional) that are included in this plan can be linked, considering that each scale area represented by different authorities with different interests. This landscape is barely considered in the Plan mostly in terms of ecological structure and not much in terms of participation and decision-making which ultimate can cost a big damage in the implementation of different measures that can be adopted in the future.

\section{Keywords}

Resilience; urban planning; climate changes; urban planning policies 


\section{Sumário}

1. Introdução 18

2. Panorama atual do contexto urbano 22

2.1. Desafios urbanos contemporâneos 25

2.2. Crise ambiental e mudança climática nas cidades 26

3. Perspectivas da criação de cidades resilientes 32

3.1 Resiliência e sustentabilidade no planejamento urbano 32

3.2 Critérios do planejamento urbano segundo Lemos (2010) 36

4. Mecanismos legais de controle do desenvolvimento urbano 48 sustentável na Colômbia

4.1 Ordenamento territorial na Colômbia 49

4.2 Plano de ordenamento territorial da cidade de Bogotá 51

5. Metodologia de avaliação de instrumentos de planejamento 66

5.1 Construção da metodologia ligando os conceitos de resiliência e 66 sustentabilidade

6. Processo de análise e classificação do POT segundo o grau de 72 contribuição e comprometimento com a resiliência urbana.

6.1 Análise de orientação do POT 72

6.2 Análise da contribuição do POT 73

$\begin{array}{ll}6.3 \text { Análise de resultados finais } & 104\end{array}$

7. Considerações finais 108

8. Referências bibliográficas 111

$\begin{array}{ll}\text { 9. Apêndices } & 118\end{array}$ 


\section{Lista de Tabelas}

Tabela 01 - Exemplo da matriz teste 68

Tabela 02 - Padrões de relação entre categorias de 69

Sustentabilidade e Resiliência

Tabela 03 - Revisão dos artigos com a categoria Promoção 74 da Integração Social

Tabela 04 - Revisão dos artigos com a categoria Eliminação 75 da Segregação Física

Tabela 05 - Revisão dos artigos com a categoria Distribuição 76

Justa de Estrutura Urbana

Tabela 06 - Revisão dos artigos com a categoria Adequação 78

do Consumo de Recursos.

Tabela 07 - Revisão dos artigos com a categoria Redução da $\quad 80$

Demanda e Estratégias de Energia limpa no local

Tabela 08 - Revisão dos artigos com Redução de Poluição.

81

Tabela 09 - Revisão dos artigos com a categoria Redução de 82

Emissões

Tabela 10 - Revisão dos artigos com a categoria Redução e

Gestão de Resíduos

Tabela 11 - Revisão dos artigos com a categoria Redução da obsolescência e ociosidade.

Tabela 12 - Revisão dos artigos com a categoria Abordagem integrada entre as escalas da cidade e natureza.

Tabela 13 - Revisão dos artigos com a categoria Abordagem integrada entre as escalas da cidade e da região.

Tabela 14 - Revisão dos artigos com a categoria 90 Biodiversidade.

Tabela 15 - Revisão dos artigos com Diversidade econômica. 92

Tabela 16 - Revisão dos artigos com Diversidade social 93

Tabela 17 - Revisão dos artigos com Reconhecimento de 94

limites do território e do desenvolvimento econômico

Tabela 18 - Revisão dos artigos com a categoria 96

Acessibilidade e mobilidade sustentável.

Tabela 19 - Revisão dos artigos com Acesso à habitação

Tabela 20 - Revisão dos artigos com a categoria saúde 100 pessoal e do ambiente

Tabela 21 - Revisão dos artigos com a Segurança física 101

Tabela 22 - Revisão dos artigos com a categoria Combate à 102 pobreza

Tabela 23 - Revisão dos artigos sobre Segurança alimentar 


\section{Lista de Figuras}

Figura 01 - Interação dos ecossistemas urbanos com as 29 mudanças do ambiente

Figura 02 - Categorias de sustentabilidade $\quad 37$

Figura 03 - Parque autormotor e taxa de aumento de veiculos $\quad 60$ por 1000 habitantes, anos 2003-2007

Figura 04 - Quantitativo de parque automotor versus viagens 61 atendidos

Figura 05 - Emissões de GEE em 2008 para Bogotá, segundo 62 a DAS

Figura 06 - Fontes hídricas que fornecem aos aquedutos da 63

Bogotá e municípios circundantes

Figura 07 - Matriz de análise de contribuição 70

Figura 08 - Categorias de classificação do grau de 71 comprometimento dos instrumentos de planejamento Figura 09 - Déficit de moradias na Bogotá, segundo estrato 97 econômico 


\section{Lista de Mapas}

Mapa 01 - Expansão urbana de Bogotá 1950 - 1990

Mapa 02 - Densidade urbana por localidade - 201053

Mapa 03 - Ameaça de alagamento pelo transbordamento do 54

Rio Bogotá

Mapa 04 - Ameaça pelos deslizamentos de terra na Bogotá 55

Mapa 05 - Programa de Melhoramento Integral Habitacional 57

Mapa 06 - Área $\left(\mathrm{m}^{2}\right)$ de solo de equipamentos por habitante 59

Mapa 07 - Estrutura Ecológica principal urbana 64 


\section{Lista de abreviaturas e siglas}

DANE - Departamento Administrativo Nacional de Estatística.

ECDPM - European Centre for Development Policy Management.

FOPAE - Fondo de prevención y atención de emergências.

GEE - Gases de Efeito Estufa.

IDEAM - Instituto de Hidrología, Meteorología y Estudios Ambientales.

IDIGER - Instituto Distrital de Gestión de Riesgos y Cambio Climático.

IPCC - Intergovernmental Panel on Climate Change.

ONU - Organização das Nações Unidas.

POT - Plan de Ordenamiento Territorial.

SDP - Secretaria Distrital de Planeación.

SDA - Secretaria Distrital de Ambiente.

UNEP - United Nations Environment Programme. 


\section{1 \\ Introdução}

Conforme a ONU Habitat (2009) a população mundial aumenta de modo acelerado, especialmente em regiões com pouca capacidade econômica e institucional para garantir o desenvolvimento urbano ordenado, preservando a natureza dentro da cidade e mantendo a saúde e o bem-estar dos habitantes enquanto leva prosperidade econômica ao pais. $\mathrm{O}$ crescimento da população e a produção mundial ocorrem na ausência de modelos de assentamentos e tecnologias suficientemente sustentáveis. Esse quadro tem multiplicado a pressão sobre o meio ambiente, além de uma nova situação conhecida como a mudança climática com consequências ainda imprevisíveis que podem afetar principalmente os assentamentos humanos.

A mudança climática suscita novos desafios principalmente para os governos e planejadores que têm de enfrentar as incertezas da frequência e a magnitude da periculosidade dos futuros eventos, sem contar com as características e problemas típicos das cidades (assentamentos precários, alta densidade, complexa mobilidade e saneamento básico incompleto). Conforme mencionado por Urwin e Jordan (2007) é evidente que as novas políticas elaboradas por setores climáticos e não climáticos precisam ser desenhadas para facilitar as decisões adaptativas.

Diante deste cenário surge uma visão de planejamento com a perspectiva da resiliência definida em Ecologia, como a medida da persistência dos sistemas e sua capacidade de absorver as mudanças, distúrbios e ainda manter o relacionamento entre as populações e suas variáveis (HOLLING, 1973).

Do conceito de ecossistemas, Walker (2004) adicionou a capacidade de reorganização do sistema na medida que sofre as mudanças, de forma que mantenha essencialmente a mesma função, estrutura, identidade e processos de retroalimentação.

De acordo com Wilson (2012) a inclusão do conceito de resiliência no planejamento urbano tem se convertido em uma ideia poderosa que ultrapassa as ciências naturais e sociais, gradualmente sendo usada como base para a tomada de decisões em estudos de complexas interações entre sociedade, gestão do uso do solo e políticas. 
$\mathrm{Na}$ busca de planejamento para estruturação de cidades sustentáveis e resilientes na Colômbia os planos de ordenamento territorial são definidos na Lei $n^{\circ}$. 388/1997, Art. 9, como o conjunto de objetivos, orientações, políticas, estratégias, metas, programas, atuações e normas adotadas para orientar e administrar o desenvolvimento físico do território e a utilização do solo Estabelece que os princípios básicos do ordenamento são a função social e ecológica da propriedade, a prevalência do interesse geral sobre o particular e a distribuição equitativa dos custos e benefícios (CONGRESSO DE COLOMBIA, 1997).

Para Massiris (2000) os objetivos descritos na referida Lei são elementos construídos em âmbitos diferentes (social, econômico, ecológico), com potenciais que podem melhorar as condições para todos os moradores das cidades, desde que a sua concepção seja compatibilizada com as políticas de meio ambiente, desenvolvimento regional, espacial e territorial, desenvolvimento social e cultural.

O novo POT de Bogotá surgiu da necessidade de atualização da política para que permitisse a execução de projetos de mobilidade, integração da gestão do risco e adaptação do conceito de mudança climática ao ordenamento territorial, e também da necessidade redefinição do gabarito das edificações em função da capacidade de suporte urbano de cada zona da cidade (PREFEITURA DE BOGOTA, 2013).

Conforme Shoshany e Goldshleger (apud Viegas et al., 2013) o planejamento do uso do solo envolve um complexo e interdisciplinar conjunto de abordagens que impacta no comportamento climático urbano. Os impactos positivos valorizam o objetivo de conhecer o tamanho do plano para a construção da resiliência e sustentabilidade requerida pelo poder público.

$\mathrm{Na}$ análise qualitativa da construção de resiliência para instrumentos de planejamento, foi conhecida a pesquisa desenvolvida por Lemos (2010), cujo resultado final foi uma ferramenta metodológica que permite avaliar o nível de contribuição de instrumentos de planejamento municipal para a adaptação e ampliação da resiliência urbana, atuando sobre a redução de vulnerabilidades socioclimáticas $^{1}$, no enfrentamento das ameaças naturais incidentes sobre o

1 As vulnerabilidades socioclimáticas são entendidas como os danos que podem ser exacerbados pelas condições sociais do local afetado pelos eventos climáticos extremos. O termo é 
espaço urbano. Esta metodologia combina os aspectos ambientais, sociais, territoriais e econômicos para definir um arranjo que permita o desenvolvimento urbano sustentável e resiliente especifico para o âmbito no qual a cidade esteja inserida.

Essa metodologia será usada nesta pesquisa para avaliar o compromisso do novo plano de ordenamento territorial de Bogotá (maior cidade da Colômbia) com os princípios de construção de cidades resilientes, face aos desafios impostos pelas incertezas da mudança climática, os riscos e suas consequências. As consequências foram evidenciadas nos anos de 2010 e 2011 com a ocorrência da intensidade do fenômeno de "La Niña"2 que causou o aumento de chuvas em mais de $300 \%$ que o normal e afetou mais de 16.000 pessoas. Como consequência das chuvas, houve o transbordamento das águas do Rio Bogotá, altamente poluído, causando uma emergência sanitária por surto infeccioso de doenças respiratórias, gastrointestinais e dermatológicas que afetaram mais de 5000 pessoas (PREFEITURA DE BOGOTA, 2013), fato que impulsionou o alarme sobre a capacidade da cidade em lidar com eventos irregulares ou fatores de risco a vulnerabilidade de populações inteiras as mudanças climáticas extremos. Do mesmo modo, mostraram a necessidade de inserir e adotar novas medidas no planejamento para incluir a proteção dos ecossistemas locais e de seus serviços ambientais, bem como diminuir os assentamentos em áreas de risco.

A pesquisa inicia com uma sequência que começa com uma revisão do panorama atual do contexto urbano e os desafios apresentados para as cidades, onde mais da metade da população reside em cidades e com o crescimento acelerado ocorre o aumento da poluição e a mudança climática, situações que poderiam gerar colapsos urbanos por não atender a população e não ter um planejamento adequado.

Diante do exposto, as cidades devem se reorganizar e procurar novas formas de construir e planejar o desenvolvimento urbano. Nesse contexto surge a resiliência, tema abordado no capitulo 3 , com a descrição do conceito focada ao planejamento urbano de cidades resilientes e os critérios que podem ser adotados

descrito em DIFFENBAUGH, N. et.al. Indicators of 21 st century socioclimatic exposure. Artigo que estuda o fenômeno.

${ }^{2}$ Este fenômeno se trata do enfreamento a grande escala das temperaturas da superfície do oceano na mesma região do Pacífico equatorial, somado a uma inversão das condições da atmosfera suprajacente. Organização Meteorológica Mundial, 2014 
pelos planejadores urbanos para que as cidades tenham melhores capacidades de adaptação aos desafios mencionados anteriormente. Este capítulo também aborda as categorias de resiliência que serão correlacionadas na pesquisa por sua relação direta com os artigos do plano a ser avaliado.

No capítulo seguinte são descritos os mecanismos legais de controle do uso do solo no desenvolvimento urbano, com a revisão de algumas experiências sobre planos de ordenamento e ferramentas legais adotadas para uma avaliação qualitativa, que permite conclusões sobre as tendências dos mesmos na construção de cenários futuros de resiliência urbana. Em seguida, é efetuada a introdução ao tema do Plano de Ordenamento Territorial (POT) de Bogotá, com exposição das tendências que levaram à reestruturação do mesmo e exposição das justificativas que levaram o poder público a adotar medidas para enfrentar as situações de risco.

No capítulo 5 é descrita a metodologia usada para avaliar o novo plano com critérios de sustentabilidade e resiliência, segundo Lemos 2010, assim como sua possível orientação e contribuição na construção destes aspectos na cidade.

A parte final apresenta a análise, os resultados e as considerações finais, no qual pode-se constatar qualitativamente que o Plano da Bogotá contribuirá de forma positiva na construção e desenvolvimento de uma cidade mais sustentável e resiliente. 


\title{
2 \\ Panorama atual do contexto urbano
}

Atualmente, as cidades são o eixo central de diversas preocupações. Segundo Turok (2014), as cidades encorajam a criação de riqueza e geram trabalho aproveitando as forças das aglomerações e a industrialização. As altas concentrações do capital financeiro, humano, intelectual e físico estimulam o progresso econômico. Nelas é possível encontrar visão, desenvolvimento, oportunidades, tecnologia e ciência, mas também pobreza, desigualdade, poluição.

\begin{abstract}
É estimado que as áreas urbanas representam $70 \%$ do Produto Interno Bruto mundial e elas tem gerado crescimento econômico e prosperidade para muitos. Contudo quando não é corretamente desenhada e gerida, as cidades pagam frequentemente o alto preço das externalidades negativas, como os engarrafamentos, a poluição e múltiplas iniquidades. (ONU HABITAT, $2015)^{3}$
\end{abstract}

Os sistemas urbanos atuais estão sendo afetados negativamente por decisões tomadas no passado que orientaram o desenvolvimento das cidades, particularmente relativas à maneira de lidar com certos desafios que agora são exacerbados, por novos problemas tais como o aumento populacional, a mudança climática o declínio da qualidade das matrizes abióticas (solo, água, ar) o esgotamento dos recursos não renováveis.

Segundo Naredo (2000), até 1850 apenas duas cidades no mundo superavam um milhão de habitantes, em 1900 já existiam dez cidades com mais um milhão de habitantes, em 1910 já tinham treze, hoje, entre as aglomerações acima de 10 milhões de habitantes, estão Nova York, México, São Paulo, Calcutá, Shangai, Beijing e etc.

Segundo a Lei $\mathrm{n}^{0} .128 / 1994$, Art. 1, a área metropolitana de Bogotá é definida como uma entidade administrativa, formada por um conjunto de dois ou mais municípios integrados ao redor de um município núcleo ou metrópole, vinculados entre si por estreitas relações de ordem física, econômica e social para a

3 ONU-HABITAT. Global Country Activities Report: 2015 - Increasing Synergy for Greater National Ownership, p. 2. 
programação e coordenação de seu desenvolvimento, com a racionalização da prestação dos serviços públicos, fato que requer uma administração coordenada para atender a projeção estimada por DANE (2005) no qual Bogotá até 2020 deve alcançar o quantitativo de mais de 10 milhões de habitantes.

Toda esta situação de crescimento populacional acelerado também gera uma desigualdade insustentável. Segundo o UN-Habitat (2016), no Século XXI, ainda persistem alguns problemas do passado como o crescimento urbano desordenado, a mudança nos padrões familiares, o aumento das favelas ou assentamentos irregulares, e os desafios de provisão dos serviços básicos para todos os moradores. Além disso, se refere à promoção de outros problemas como as mudanças climáticas, o aumento da inequidade (medida pelo coeficiente Gini), a exclusão, a inseguridade e o aumento das migrações. A mudança climática á muito conectada às cidades pela infraestrutura e indústrias instaladas, tanto por consumir energia quanto pelas emissões de gases que provocam o Efeito Estufa.

Estudos feitos pela Universidade de Nova York, mostram claramente que enquanto a população nas principais cidades tem aumentado uma média de 17\%, a ocupação de área nas mesmas cidades cresceu 28\%, isto apresenta uma realidade de ocupação com baixa densidade e ineficiente uso do solo que é uma preocupação adicional produto da expansão das cidades além dos limites físicos. Os impactos ambientais pela expansão incluem rompimento dos ciclos hidrológicos e biológicos, perda da biodiversidade e do habitat, concentração de sustâncias poluentes, geração de resíduos sólidos e ilhas de calor (UNEP, 2007).

Conforme mencionado por Birkman et al (2010), as áreas urbanas implicam em diferentes escalas, de tamanho e densidade da população, área do ambiente construído, aglomeração de infraestrutura, e velocidades de processos de desenvolvimento e mudanças. Destaca também que a concentração espacial de população, infraestrutura e equipamentos leva ao aumento das concentrações na exposição e danos potenciais dentro das cidades.

Esta situação comum as grandes cidades implica na presença de riscos ambientais que de acordo com Veyret e Meschinet (2007), são o resultado da associação dos riscos naturais com os riscos decorrentes de processos naturais agravados pela atividade humana e pela ocupação territorial.

O mundo globalizado e conectado com as maiores cidades, onde estão concentrados os poderes econômicos são as maiores preocupações. Conforme a 
UN-Habitat (2007), as cidades ligadas aos sistemas financeiros regionais ou globais tem o potencial de espalhar as consequências negativas pela economia global, devido à concentração de pessoas, capital centros políticos e culturais.

Para Wamsler et al (2013), uma análise abrangente do contexto cidade-desastres, precisa considerar todos esses fatores e afirma que a qualidade da complexidade faz parte das cidades atuais com processos e interligações outorga a responsabilidade, de desempenhar um papel fundamental no funcionamento dos sistemas econômicos, políticos e sociais de maior envergadura.

Black et al (2011) destaca que a natureza e escala dos desafios que as cidades estão enfrentando demandam a necessidade de estratégias de planejamento ao longo prazo.

Childers et al (2014) afirma que o planejamento do passado, focado principalmente na parte estrutural, era dominado por infraestrutura dispendiosa e rígida, com soluções desenhadas para isolar os perigos das pessoas usando redes de distribuição e coleta. Devido a infraestrutura centralizada, muitas cidades apresentam capacidade limitada para incluir adaptações e práticas sustentáveis ou são ineficientes para satisfazer as necessidades básicas e dispor os serviços públicos.

As cidades precisam adotar ações de desenvolvimento urbano e se apropriar das tendências de urbanização para encontrar soluções inovadoras. O planejamento urbano tem a responsabilidade de lidar com esses desafios, e as políticas do setor público são a resposta primária para os questionamentos que possam surgir sobre o ordenamento do espaço e o solo urbano, assim como os recursos inseridos na cidade. Não obstante é importante que esse planejamento seja pensado considerando todos os desafios anteriormente mencionados e seja baseado em uma olhada mais consciente da realidade dos problemas que surge quando o cruzamento de limites ambientais e a realidade da mudança climática entram em cena urbana e causam impactos para os quais nem a cidade nem seus habitantes estão preparados.

Os problemas diferem de acordo com a escala da cidade, os grandes centros urbanos apresentam todos os problemas socioambientais descritos, mas pelo fato de ter uma institucionalidade organizada, têm a capacidade de lidar com todas as situações apresentadas com grupos de trabalho em todos os campos. 
Por outro lado, as cidades medianas ou pequenas que também estão crescendo rapidamente e não estão preparadas institucionalmente para enfrentar os problemas e desafios já mencionados.

\section{1}

\section{Desafios urbanos contemporâneos}

Conforme a UN-Habitat (2016) o crescimento espacial e o atual modelo de urbanização são motivados pelos interesses privados, não públicos com formas de inequidade e exclusão criando nas cidades divisão das comunidades "fechadas" e áreas de favelas. O rápido crescimento nos países em desenvolvimento, que ocorrem principalmente nas áreas de baixa renda (assentamentos informais) são considerados um problema persistente, fato que aumenta população vulnerável.

Os processos urbanos informais, geram um impacto ambiental trazem consigo a implantação de um conjunto físico-espacial caracterizado pela não existência de normativas urbanísticas, o déficit para o acesso de serviços públicos domiciliários e infraestrutura assim como a utilização de terrenos inadequados para construir e urbanizar, isto contribui com intervenções pouco adequadas aos contextos geográficos e de localização do hábitat e a vivenda (CASTILLO DE HERRERA, 2009). As cidades devem assegurar o acesso aos serviços básicos como saneamento, agua potável, mobilidade, energia, coleta de resíduos para garantir condições de saúde e bem-estar público e ambiental. É preciso que haja um planejamento que assegure o acesso efetivo aos recursos e espaços públicos, de modo a contribuir com a redução das desigualdades.

Nos aspectos econômicos, devido ao difundido desemprego, as cidades mantêm altas taxas de informalidade, baixos salários e população jovem longe da estabilidade laboral, gerando problemas econômicos e difícil aceso aos serviços urbanos, a urbanização mal planejada diminui o potencial das economias de aglomeração existentes nas cidades (UN-HABITAT, 2016).

Nessas condições de inequidade a mudança climática tem emergido como um problema urbano e torna-se uma ameaças principalmente nas áreas informais (UN-HABITAT, 2016), por isso, o planejamento urbano com a identificação de riscos e de sua gestão torna-se um desafio e uma oportunidade para as cidades dos próximos anos. 
A projeção de que a população humana se duplicará até o ano 2050 (PIACENTINI et al, 2016) significa que haverá número maior de pessoas expostas às mudanças climáticas em ambientes já muito vulnerável aos efeitos da mesma. A inovação nas formas de lidar com as incertezas desta mudança, vão contribuir na construção de um ambiente mais equitativo.

Como o crescimento populacional também vem o aumento a demanda de energia e água, estimada em mais em 40\% e 50\% para 2030 (ECDPM, 2012). Este panorama é preocupante e pode ser visto como uma oportunidade para gerar ações que sejam determinantes na mudança de paradigmas de concepção de centros urbanos, evitando isolar as cidades e seus problemas, mas vendo as conexões espaciais e a ligação dos impactos como a perda de biodiversidade e deflorestação. Da mesma maneira a demanda de energia, irá acelerar a mudança de fontes de energia fósseis para outras menos poluentes e mais sustentáveis.

Outra preocupação da urbanização é a expansão das cidades além dos limites sustentáveis, com consequência reduz as áreas para agricultura, fato que pode representar uma diminuição na segurança alimentar da população.

A expansão urbana que ocorre pela dificuldade na mistura dos usos do solo, impacta na poluição do ar, pelo aumento da mobilidade de veículos particulares percorrendo grandes distâncias desde as áreas suburbanas (bairros e condomínios) até as zonas de trabalho, com altas emissões de Gases Efeito Estufa. Esta poluição é consequência do modelo de baixas densidades de ocupação, que trazem aumento dos custos na provisão de serviços públicos, pela conformação de infraestrutura adicional.

\title{
2.2
}

\section{Crise ambiental e mudança climática nas cidades}

\begin{abstract}
“É extremamente provável que mais da metade do observado aumento na temperatura superficial global desde 1951 até 2010 seja causado pelo aumento humano da concentração de GEE e outras forças humanas conjuntas".
\end{abstract}

$(\text { IPCC, 2014) })^{4}$

${ }^{4}$ INTERGOVERNMENTAL PANEL ON CLIMATE CHANGE IPCC. Climate Change 2014: Synthesis Report, p. 5. 
A mudança climática está aumentando a magnitude das ameaças nas áreas urbanas, fato constatado em zonas de rápida urbanização. Nas cidades os efeitos da mudança climática estão relacionados com as características locais e são diferenciados pelas condições do clima local e sua forma de interação com o ambiente urbano.

A expansão urbana, remove a vegetação nativa para abrir solo para construção de edificações e rodovias (NEWMAN e JENNINGS, 2012). Sem vegetação o processo de infiltração é baixo e o aumento do run-off é iminente. Como consequência desta intervenção na paisagem, se causa a erosão do solo e a perda de estabilidade do mesmo.

Num mundo mais quente os eventos extremos relacionados com fortes chuvas, serão mais frequentes. A realidade indica que a mudança climática tem efeitos principalmente devastadores sobre os pobres das áreas urbanas (IPCC, 2014); ocupantes dos assentamentos informais. Na periferia das cidades, estes eventos estarão acompanhados de alagamentos e movimentação de terra, causando deslizamentos, destruição de moradias e até perda de vidas (UNEP, 2002).

Outra situação climática extrema está relacionada à seca, pois as fontes de água serão insuficientes para o abastecimento de água potável para toda população urbana, e os mais afetados serão os habitantes de baixas rendas, cujo abastecimento já é difícil, pela localização longe das infraestruturas principais de aqueduto e esgoto (UNEP, 2011).

Os impactos negativos da seca são produto não só da mudança climática, mas da mesma diminuição dos ecossistemas naturais, que reduz a capacidade dos mesmos, de prover os serviços ambientais tão necessários nas cidades (MILLENNIUM ECOSYSTEMS ASSESSMENT, 2005).

A mudança climática pode afetar o ciclo da água de várias maneiras, incluindo, mudança nos padrões de precipitação, redução da vazão e fluxo nos rios e diminuição nos níveis de agua subterrânea (IPCC, 2014).

Ao mesmo tempo a mudança climática afetará a demanda e a oferta de energia (UN-HABITAT, 2016). A demanda aumentará devido o crescimento populacional, à mudança das condições climáticas, as ilhas de calor (geradas pelo calor emitido pelas atividades humanas e a redução na evapotranspiração pela impermeabilização das superfícies), crescimento econômico, etc. 
A diminuição da oferta afetará a distribuição da água, principalmente nos países com alta produção hidroelétrica. Na Colômbia, no primeiro semestre de 2016, ocorreu uma forte seca que causou alarme nos principais reservatórios do país devido aos baixos níveis que dificultaram a produção de energia. Esta situação pode acrescentar problemas sociais derivados do conflito pelo aceso à água, pois a indústria precisa da água para produzir e aumentar o desenvolvimento econômico, além disso, a à agua é um elemento vital para a sobrevivência humana, razão pela qual a prioridade de abastecimento para a população pode desencadear outros conflitos no âmbito da justiça social (MARTíN e BAUTISTA, 2015).

A disponibilidade da água relacionada com os efeitos da mudança climática pode gerar vários problemas nas atividades econômicas de uma região. As indústrias podem ser afetadas pelos eventos extremos através dos danos à infraestrutura e aos bens, podem ocorrer atrasos na mobilidade e transporte de mercadorias das quais dependem as grandes indústrias, pode ser afetada a sua linha de produção pela interrupção do fluxo de matérias primas ou de energia, causando o aumento nos preços de produção e encarecendo o custo de vida.

Os efeitos na disponibilidade de bens, principalmente da agricultura e da segurança alimentar revelam que a mudança climática terá efeitos devastadores na produção de alimentos (IPCC, 2014), seja pela diminuição ou pelo aumento de precipitações, que pode gerar perda da produção agrícola, escassez da água ou alagamentos que podem aumentar as doenças e propagar pestes nas culturas, fato que poderá atingir as grandes cidades pela alta dependência ao alimento produzido em áreas distantes.

Os problemas gerados pela mudança climática causarão uma migração ainda maior para as cidades, produtos dos deslocamentos da população afetada pelos eventos extremos ou o aumentos do nível do mar, esta situação colocará mais pressão nas cidades, principalmente àquelas que não possuem um planejamento estruturado e baixa capacidade institucional de resposta, exacerbando os problemas anteriormente descritos, aumentando ainda mais o tamanho dos assentamentos informais e o espalhamento da área urbana (BLACK et al, 2012).

Nesse sentido, a mudança climática é um fator importante na aceleração da perda e degradação dos ecossistemas, o processo de urbanização por ele mesmo também tem sido uma forca motivadora de mudança da paisagem e dos ciclos 
naturais. Segundo o Grimm et al (2008), o crescimento urbano tem consumido muitas matérias-primas, alterado o uso da terra e sua cobertura, modificado o ciclo da água local e global, aumentado a geração de resíduos sólidos e afetado os ciclos biogeoquímicos do planeta.

A interação dos ecossistemas urbanos, as mudanças do ambiente e os principais impactos estão representados na Figura 1.

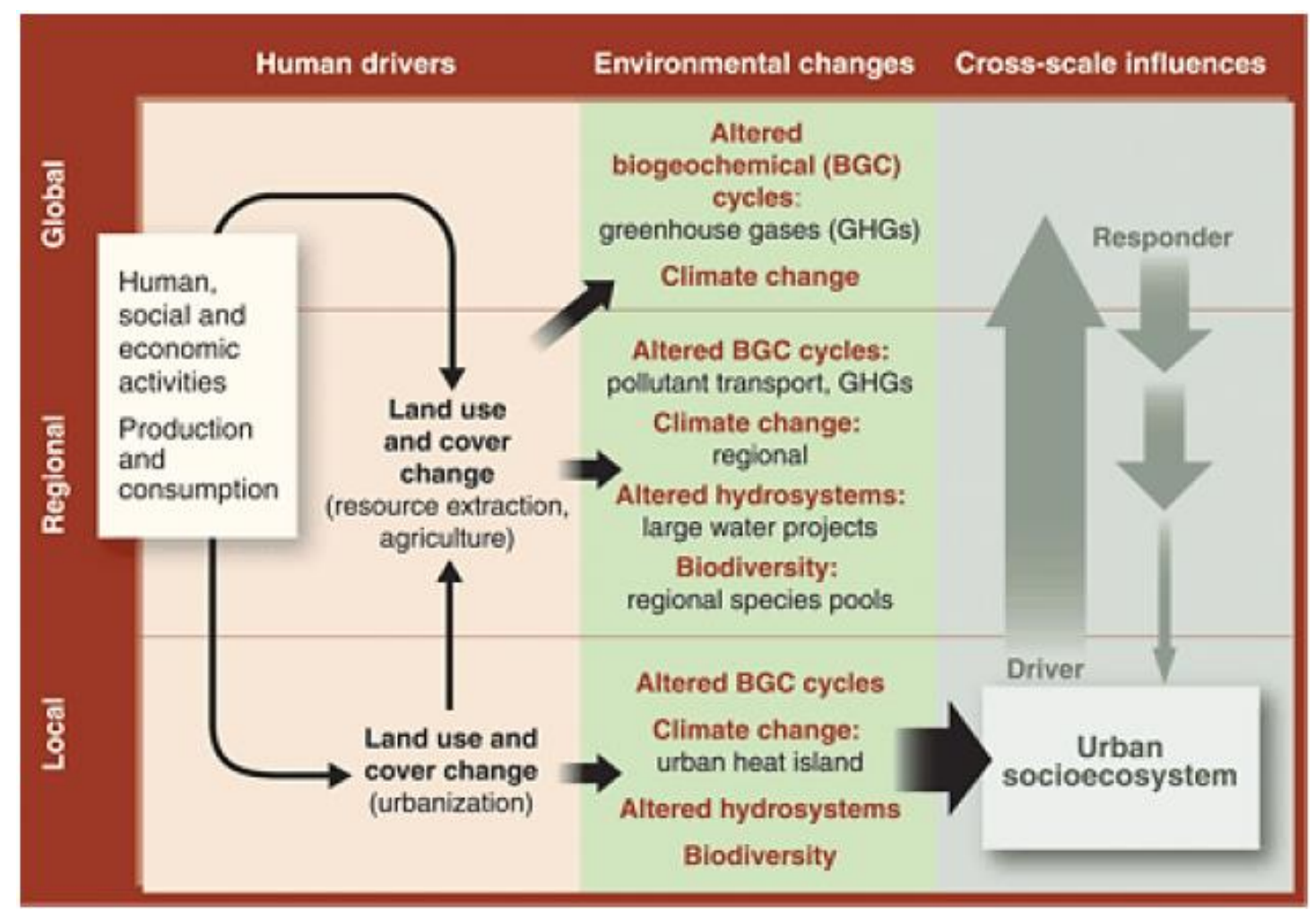

Fonte: Grimm et al, 2008, p.3

Figura 1 - Interação dos ecossistemas urbanos com as mudanças do ambiente

A Avaliação Ecossistêmica do Milênio (2005), encontrou que mais da metade dos serviços prestados pelos ecossistemas tem sido degradados ou usados de maneira insustentável. Na medida em que as cidades têm que suprir os serviços ecossistêmicos perdidos, a moradia custa mais caro o que representa uma pressão econômica maior para as populações mais pobres.

A mobilidade é outro grande problema das cidades atuais. É esperado que a cidade provenha acesso aos bens e serviços, ao mercado local, às conexões sociais e as diferentes atividades de lazer, entre outros. Segundo ONU-Hábitat (2014), os esforços nas cidades para melhorar a mobilidade interna através de bons sistemas de transporte público poderá igualar o acesso aos recursos da cidade e assim ao 
valor territorial, porém a mobilidade representa atualmente um desafio, pois em muitos casos é o contrário do esperado e a tendência é priorizar o uso do carro particular (ONU-HÁBITAT, 2014), é altamente segregadora, com grandes investimentos em infraestrutura ampla e dispendiosa, principalmente rodoviária, que consome muitos recursos, gera rompimento dos espaços, dificulta o deslocamento a pé e causa inseguridade em outros modais de deslocamento, devido às altas velocidades dos carros. $\mathrm{O}$ transporte público não consegue suprir a demanda nos horários de pico, resultando em incômodos e dificultando o uso de transporte público frente à opção da comodidade oferecida pelo uso do carro particular.

Segundo o Suzuki et al (apud UNEP, 2010) o setor de transporte é uma das principais fontes de GEE e poluição no ar, gerando perto da quarta parte das emissões totais, devido aos combustíveis usados pelos carros e a configuração da cidade, pois as moradias ficam na periferia, mas o trabalho e os equipamentos ficam no centro da cidade, o que aumenta os quilômetros diários percorridos pelos cidadãos. É na estrutura da cidade que surgem muitos problemas, pois um cidade com baixa densidade representa uma ineficiência no uso do solo, da energia e do tempo de deslocamento (SUZUKI et al, 2014).

A sociedade tem discutido a eficiência como base da estruturação da cidade. Um novo modelo de cidade deve olhar sobre os erros do passado e tentar construir uma visão mais holística ligando a cidade com a natureza e os limites que esta impõe (RITCHIE e THOMAS, 2013).

O planejamento deve considerar todos os desafios impostos pelas incertezas e as condições ambientais como consequência de um processo de urbanização altamente invasivo e pouco consciente dos limites existentes.

A nova tendência de planejar considerando os critérios diagnosticados no passado deve emergir para dar forma ao novo modelo de cidade, com visão e entendimento de que os sistemas ecológicos precisam ser marco de um desenvolvimento ajustado à realidade da incerteza e da vulnerabilidade ligada à mudança climática.

Os assentamentos humanos do futuro próximo terão que lidar com distúrbios causados por fatores externos, acrescentados pela mudança climática e enquanto lidam com estes eventos devem ficar e sair adiante, se recuperar e manter suas funções como motor de desenvolvimento e inovação. 
Até os dias atuais, o planejamento foi concebido para fazer um modelo fechado com tudo controlado, mas as cidades precisam ser mais flexíveis, precisam reutilizar recursos, ser mais eficientes, diversas, justas, misturadas, reconhecer seus limites e se conectar com seus arredores, planejar conjuntamente e transmitir seu conhecimento.

Para poder facilitar as ações e guiar o caminho dos políticos e tomadores de decisões é importante elucidar os aspectos mais importantes sobre a resiliência e como este conceito pode ser inserido no planejamento urbano com a finalidade de construir leis, documentos e planos com ações reais que permitam alcançar os objetivos de construir cidades mais sustentáveis e melhor adaptadas para enfrentar os desafios das transformações ambientais.

A mudança na visão do planejamento e a discussão da tendência do planejamento das cidades são abordados no capítulo seguinte. 


\section{3 \\ Perspectivas da criação de cidades resilientes}

O termo resiliência é um dos maiores conceitos atuais na busca de mecanismos para alcançar a sustentabilidade do mundo e da civilização tal como é conhecida. A tendência do uso deste termo está conexa com a nova perspectiva das ciências, de olhar às cidades e outros sistemas sócio ecológicos complexos, como sistemas mutáveis em constante movimento que não podem ser estudados desde pontos de vista estáticos, pois evoluíram de maneira muitas vezes imprevisível (FOLKE et al, 2002).

O conceito é usado em muitas ciências, como na Psicologia, Física, Direito, mas nesta dissertação será adotado com sentido de Ecologia, onde resiliência é definida como a medida da persistência dos sistemas e sua capacidade de absorver as mudanças e distúrbios e ainda manter o mesmo relacionamento entre populações e suas variáveis (HOLLING, 1973), com algumas variações aplicadas ao planejamento urbano. Resiliência é a habilidade de um sistema para absorver distúrbios e ainda manter suas funções e estruturas básicas (WALKER e SALT, 2006).

Conforme argumentado por Tidball e Krasny (2007), as ações de integração de capital social, natural, econômica e físico nas cidades procuram diversidade, auto-organização, gestão e aprendizagem adaptativa, levam à retroalimentação positiva com o potencial de reduzir o risco de desastres nas cidades, ajudando às comunidades no desenvolvimento de resiliência antes e depois do desastre.

\section{1}

\section{Resiliência e sustentabilidade no planejamento urbano}

No contexto dos sistemas sócio-ecologicos complexos (como as cidades) é importante considerar o grau ao qual o sistema é capaz de se auto-organizar e o grau do sistema em poder desenvolver a capacidade para aprendizagem e adaptação às mudanças que possam ocorrer.

No entanto Pickett et al (2013), adverte que nem todas as mudanças teriam que ser aceitadas, já que os limites dos sistemas ecológicos inseridos nas cidades, 
devem ser considerados no ato de desenhar e construir o ambiente urbano, sugere que aqueles limites podem ser extrapolados para limites sociais, econômicos e de engenharia, cada um com sua importância na conformação do desenho urbano.

Segundo o Ahern (2011) a resiliência requer a construção de uma infraestrutura social que assegure a participação dos grupos de interesse no planejamento e a decisão política. A governança e o empoderamento das comunidades é vital para alcançar a resiliência das cidades, pois uma comunidade resiliente tem mais possibilidade de se adaptar a mudanças inesperadas e sem precedentes (FOLKE 2002 e AHERN, 2011).

No contexto das incertezas da mudança climática Jabareen (2012) destaca que são importantes as definições de quatro conceitos (vulnerabilidade, governança urbana, prevenção e planejamento orientado à incerteza) para moldar o marco conceitual da resiliência.

Segundo o IPCC (2007):

\begin{abstract}
"vulnerabilidade é o grau de susceptibilidade ou incapacidade de um sistema para lidar com os efeitos adversos da mudança do clima, inclusive a variabilidade climática e os eventos extremos. A vulnerabilidade é uma função do caráter, magnitude e taxa da mudança do clima e da variação a que um sistema está exposto, assim como a sensibilidade e capacidade de adaptação daquele sistema"
\end{abstract}

$\left(\right.$ IPCC, 2007) ${ }^{5}$

Para Jabareen (2012), a vulnerabilidade é determinada em termos de vulnerabilidade demográfica, informalidade, incerteza e distribuição espacial da mesma. A governança urbana é fundamental na construção de uma cidade resiliente considerando que este conceito faz o processo de tomada de decisões mais inclusivo no planejamento, facilita o diálogo, promove a responsabilidade e a colaboração. E os componentes da governança urbana são a abordagem integrativa, a equidade e economia ecológica.

A prevenção indica a importância de procurar prevenir danos ambientais e impactos da mudança climática. A prevenção procura mitigar, reestruturar e aplicar energias alternativas (JABAREEN, 2012).

\footnotetext{
${ }^{5}$ IPCC. Climate change 2007: impacts, adaptation and vulnerability, p. 883.
} 
O conceito final é o planejamento orientado à incerteza que define basicamente a necessidade de repensar e revisar os planos atuais e os mecanismos de planejamento, considerando as incertezas causadas pelas mudanças climáticas. Este planejamento deve estar composto por bases de adaptação, planejamento espacial e forma urbana sustentável.

A resiliência é assim um mecanismo que possibilita a construção de sustentabilidade nas cidades, definindo o grau de vulnerabilidade do ambiente urbano, as políticas de participação e inclusão da população geral da cidade, o reconhecimento da prevenção como mecanismo para reduzir os efeitos da mudança climática e a construção de um planejamento que mude a orientação das estratégias de atuação em conjunto com as premissas da forma de ocupação do espaço construído.

A resiliência e a sustentabilidade urbana nos permitem observar, como ponto em comum, a necessidade de integrar as cidades, de forma sinérgica, com o meio natural (SIEBERT, 2013).

Uma das premissas dessa pesquisa e da aplicação da metodologia de avaliação é a relação entre sustentabilidade (especificada nas categorias de sustentabilidade abaixo explicadas) e a contribuição destas com a resiliência, entendida como a redução da exposição, da sensibilidade e a ampliação da capacidade adaptativa, componentes da vulnerabilidade.

Na execução de planos para o ordenamento urbano, assim como na construção de resiliência desde a perspectiva do planejamento, propõe se incluir, segundo o descrito por Ahern (2011), as seguintes estratégias: a multifuncionalidade, a redundância, a diversidade social e biológica, a conectividade multiescalar, o planejamento e desenho adaptativo.

A multifuncionalidade é o ponto chave no conceito futuro de cidades compactas com espaços limitados porque possibilitará que o planejamento inclua ambientes misturados, com funções entrelaçadas que permitam a eficiência espacial e econômica. Além disso, tem o potencial de construir um sistema diverso de suporte público com múltiplos grupos de interesse associados a funções particulares (NAVEH, 2001). Esta estratégia pode ser ligada às seguintes categorias de sustentabilidade denominadas de Promoção da Diversidade e Abordagem integrada (LEMOS, 2010).

A redundância se refere ao planejamento da provisão de diferentes funções ou 
serviços de maneira descentralizada, se uma das fontes prestadoras falhar, as outras podem continuar cumprindo aquela função sem maiores contratempos. As categorias da metodologia que podem ser aplicadas à estratégia mencionada são: aumento da durabilidade e redução da ociosidade.

Uma situação similar poderá acontecer no caso do conceito de diversidade social e biológica, no qual indica que quanto maior o número de espécies fazendo uma mesma função dentro de um ecossistema, menor é a possibilidade de colapso frente a um distúrbio. Quando a diversidade social é ainda mais simples, aquelas cidades com diversidade de comunidades e de economias são menos suscetíveis a comoções deste tipo. As categorias de sustentabilidade relacionadas com este aspecto são Integração e justiça social e físico-territorial, e Promoção da diversidade.

A conectividade multiescalar é importante nas cidades que são sistemas de múltiplas escalas, como por exemplo na mobilidade, a cidade tem pedestres, bicicletas, automóveis, ônibus, metrô, trens, etc., todos interagindo no mesmo espaço, por isso as cidades têm que ser planejadas para conectar atores e facilitar seu deslocamento sem afetar aos outros.

Outros exemplos da importância da conectividade na cidade são os ecossistemas urbanos e como através daquela conectividade é possível manter a saúde deles e seus serviços ambientais para a população. Este aspecto inclui as seguintes categorias de sustentabilidade: Acessibilidade e mobilidade sustentável; Integração e justiça social e físico-territorial; e Abordagem integrada.

Além disso, dentro das estratégias e critérios que devem ser consideradas no planejamento de cidades resilientes está o desenho e planejamento adaptativo que consiste em aprender com aquilo que já foi feito e monitorando, analisando-se as decisões já tomadas e suas consequências visando gerar conhecimento sobre os processos particulares. Assim, se encontra uma relação entre este aspecto e as seguintes categorias de sustentabilidade: Adequação da relação com recursos naturais e o ambiente; e Reconhecimento dos limites.

Estas categorias de sustentabilidade ligadas com a estratégias propostas por Arhem (2011) devem ser incluídas nos planos gerados pelos organismos de controle e desenvolvimento urbano, com o objetivo de construir cidades que possam lidar com as incertezas do futuro, sem perder a essência da cidade como eixo do desenvolvimento e a oportunidade. É nesse aspecto que o planejamento 
tem que atingir, procurando a mistura de conceitos e mecanismos alternativos aos já desenvolvidos e a concepção de novas formas de planejar que incluam a população e demais atores do entorno urbano.

\section{2 .}

\section{Critérios do planejamento urbano}

As categorias de sustentabilidade mencionadas acima, fazem parte da proposta metodológica criada por Lemos (2010), na qual se propõe avaliar os instrumentos de planejamento desde o relacionamento entre a sustentabilidade e a resiliência descrito nas ações descritas pelo mesmo instrumento.

Segundo Lemos (2010) o método é baseado em quatro pressupostos:

1. Um diagnóstico específico de vulnerabilidade, baseado num cenário climático de uma área específica, é condicionante para a adaptação. Isto é importante tomando em conta que se a vulnerabilidade de um local é conhecida e integrada no planejamento podem ser estabelecidos limites para o desenvolvimento urbano em aquelas áreas identificadas ou podem ser criadas leis que façam o desenvolvimento restrito a certas condições especificas de construção ou de adensamento.

2. A relação entre sustentabilidade e resiliência é estreita, razão pela qual podem ser ligados princípios de planejamento para a sustentabilidade urbana com ações de contribuição para a resiliência da cidade. Os princípios de sustentabilidade são uma ponte entre a orientação do POT (artigos) e os possíveis resultados daquelas decisões sobre a resiliência urbana

3. As medidas de adaptação devem ser produto de um planejamento antecipatório de risco futuro. Entendendo que o POT tem a capacidade de olhar para o futuro, base mesma do planejamento, as orientações propostas procurarão a adaptação num meio de incertezas próprias da mudança climática.

4. A construção de políticas com miras a cidades resilientes é imperiosa. Agora mesmo a política está mudando o discurso do planejamento urbano, baseado no crescimento das cidades e as evidencias cientificas da existência da mudança climática e como esta pode afetara estabilidade das aglomerações e sua capacidade de suportar distúrbios. 
Cada categoria implica no planejamento e ações que terão resultados positivos ou negativos, na construção de resiliência com o alvo de sustentabilidade urbana. Essas categorias podem contribuir com a mitigação, principalmente avaliada pelas medidas na redução das emissões de GEE e podem auxiliar na antecipação de medidas antes da ocorrência dos eventos.

As categorias também podem causar redução da sensibilidade e da exposição, ou podem aumentar a capacidade adaptativa das populações numa cidade.

As categorias de sustentabilidade de acordo com a metodologia de avaliação estão representadas na Figura 2 juntamente com as sub-categorias que serão utilizadas na construção das matrizes propostas pela metodologia e que serão avaliadas para cada um dos artigos contidos no POT da Cidade de Bogotá.

\begin{tabular}{|c|c|}
\hline \multirow{3}{*}{$\begin{array}{l}\text { INTEGRACÄO E JUSTICCA SOCIAL E FISICO- } \\
\text { TERRITORIAL }\end{array}$} & PROMOÇÃO DA INTEGRAÇÃOO SOCIAL \\
\hline & ELMINAÇÃO DA SEGREGAÇÄO FISICA \\
\hline & DISTRIBUIÇÃo JUSTA DE ESTRUTURA URBANA \\
\hline \multirow{5}{*}{$\begin{array}{l}\text { ADEQUAÇÃO DA RELACÃ̃O COM RECURSOS } \\
\text { NATURAIS E O AMISIENTE }\end{array}$} & ADEQUAÇÄO DO CONSUMO DE RECURSOS \\
\hline & REDUÇÃo DA DEMANDA E ESTRATÉGIAS DE GERAÇÃO DE ENERGIA LIMPA LOCAL \\
\hline & REDUÇÃO DE EMISSÕES \\
\hline & REDUÇÃO DE PQLUIÇ̃OO \\
\hline & REDUÇÃO E GESTÃO DE RESÍDUOS \\
\hline \multirow{2}{*}{$\begin{array}{l}\text { AUMENTO DA DURABIUDADE E REDUÇÂA DA } \\
\text { OCIOSIDADE }\end{array}$} & AUMENTO DA DURABIUDADE \\
\hline & REDUÇÃO DA OBSOLESCÉNCIA E OCIOSIDADE \\
\hline \multirow{3}{*}{ ABORDAGEM INTEGRADA } & ABOFDAGEM INTEGRADA ENTRE AS ESCALAS DA CIDADE E DA REGLÂO \\
\hline & ABOFDAGEM INTEGRADA ENTRE CIDADE E NATUREZA \\
\hline & ABOFOAGEM INTEGRADA ENTRE FORMA, FLUXOS E ATIMDADES \\
\hline \multirow{4}{*}{ PROMOÇÃO DA DIVERSIDADE } & DIVERSIOADE DE VIDA (BIOBIVERSIDADE) \\
\hline & DIVERSIOADE ECONOMMICA \\
\hline & DIVERSIDADE DE FORMA \\
\hline & DIVERSIDADE SOCIAL \\
\hline \multirow{3}{*}{ RECONHECIMENTO DE LIMITES } & RECONHECIMENTO DE LMITES DO IERRITÓRIO \\
\hline & RECONHECIMENTO DE LUMITES DE DENSIDADE \\
\hline & RECONHECIMENTO DE LUMITES DO DESENYOLVIMENTO ECONÓMICO \\
\hline \multirow{6}{*}{$\begin{array}{l}\text { TEMÁTICAS SETORLAIS PAFA A } \\
\text { SUSTENTABIUIDADE }\end{array}$} & ACESSIBIUDADE E MOBIUIDADE SUSTENTÁVEL. \\
\hline & ACESSOÁ HABITAÇقQ \\
\hline & SAÚDE PESSOAL E DO AMBIENTE \\
\hline & SEGURANÇA FISICA \\
\hline & SEGURANÇA PSICOLÓGICA \\
\hline & COMBATE A POBREZA \\
\hline
\end{tabular}

Fonte: Lemos, 2010, p. 168.

Figura 2 - Categorias de sustentabilidade 
Segundo a UN-Habitat (2016), a integração social no planejamento apropriadamente gerido pode ser um mecanismo de erradicação da pobreza. A segregação é um indicador da "distância social" dos grupos. O planejamento espacial, pode suportar oportunidades para os pobres. As populações segregadas poderiam ser beneficiadas com a proximidade aos grupos de alta renda, que sempre tem melhor aceso aos estabelecimentos educativos, segurança e conexões sociais e desta maneira facilitar novos empregos e oportunidades para outros grupos historicamente menos favorecidos.

O fortalecimento das redes de infraestrutura nos bairros de baixa renda também são mecanismos que podem integrar a exclusão urbana. $\mathrm{O}$ uso e acesso à tecnologia sob condições favoráveis pode melhor a governança e a participação das populações vulneráveis e excluídas.

De qualquer maneira, segundo o Blanco et al (2009), as políticas que são desenhadas para inibir os processos de gentrificação e deslocamento, têm o efeito encorajante de diversificar a sociedade, e contribuem para o aumento da habitação no centro da cidade.

A diversidade social é promovida pela construção de empreendimentos com novas habitações com mistura de rendas, o espalhamento de habitação social em áreas de alta renda ou a entrega de subsídios estaduais para compra de habitação em áreas de alta renda. Esse tipo de política deve ser adotado pelo planejamento se houver o intuito de misturar de pessoas e incluir habitantes mais vulneráveis aos bens e serviços oferecidos pelas cidades.

No caso da distribuição mais justa da infraestrutura urbana, o acesso a equipamentos como escolas, universidades, hospitais, parques e outras infraestruturas de serviços e lazer, pode melhorar as condições de vida dos habitantes, incluindo os mais pobres que terão menos custos para deslocarem-se.

No caso da Adequação da relação com recursos naturais e o ambiente é preciso considerar a chamada pegada ecológica das cidades, em virtude do impacto causado pelas cidades por trás do consumo de recursos, como a subsequente emissão de GEE, entre 1950 e 2005 que como o nível de urbanização e sua população aumentaram de $29 \%$ para $49 \%$, enquanto que as emissões mundiais de $\mathrm{CO}_{2}$ da queima de combustíveis fósseis aumentaram 500\% (UNEP, 2011), o aumento na geração de resíduos e a poluição do ar, água e solo, por isso, o planejamento baseado na resiliência e na busca da sustentabilidade deve desenhar 
cidades que prosperem sem causar danos e impactar o ambiente de maneira irreversível e que dificulte a vida futura.

Segundo o IPCC (2007) que inclui estratégias na redução das fontes de GEE e o aumento dos sumidouros de GEE, o principal objetivo é a redução das emissões de GEE, uma das maiores causas do aquecimento global e a subsequente mudança climática e uma efetiva medida de mitigação, entendendo a mitigação como uma intervenção antropogênica que reduz a pressão humana sob o sistema climático.

A redução pode ocorrer pela redução na geração de resíduos e diminuição da destinação final em aterros sanitários e consequentemente do biogás produzido pela decomposição dos microrganismos, além disso, com o uso de tecnologia para captação de biogás, o mesmo poderá usado na geração de energia o que leva a uma segunda forma de redução de GEE.

Segundo a UNEP (2015) as cidades representam mais do $70 \%$ da demanda mundial de energia, razão pela qual a mudança das políticas e matrizes energéticas deve ser motivada e financiada pelas cidades.

As pesquisas devem se orientar na eficiência energética e no uso de energias renováveis. Da mesma forma a ampliação da matriz energética e a provisão desde diferentes fontes, reduz o risco de cortes de eletricidade pelas flutuações de energia ou diminui a dependência das mudanças dos preços de combustíveis fosseis, situação que aumentava no passado a vulnerabilidade das economias (UNEP, 2015), fortalecendo assim o sistema energético e tornando-o mais resiliente.

Ao mesmo tempo a mudança das fontes de energia pode gerar uma redução na poluição do ar, associada à diminuição das doenças e problemas de saúde, pode melhorar o ambiente urbano e reduzir o gasto com serviços médicos investidos em doenças respiratórias e doenças relacionadas à poluição hídrica, pois um grande número de fontes de água localizadas próximo aos centros urbanos têm sido poluídas, principalmente por processos industriais, fato que diminui a disponibilidade da água potável e aumenta os custos de tratamento.

O planejamento urbano se direcionar políticas e ações para diminuir a vulnerabilidade das populações de baixa renda e fortalecer a infraestrutura e os serviços que reduzem a sua vulnerabilidade.

Outra categoria de sustentabilidade a ser avaliada no planejamento é o aumento da durabilidade e redução da ociosidade que se exemplifica pela redundância de 
uma característica dos sistemas resilientes onde se procura a eficiência e a flexibilidade.

Segundo lemos, 2010 o aumento da durabilidade procura

\begin{abstract}
"Através de processos adequados de manutenção, superar a obsolescência das edificações e espaços construídos, preservando e recuperando o estoque existente de edificações como prioridade em relação a novas construções"
\end{abstract}

$\left(\right.$ LEMOS, 2010) ${ }^{6}$

Se lembra, porém, que sempre deve ser tomado em consideração que as novas construções podem ser fontes de geração de emissões de gases efeito estufa, pelos mecanismos de construção e pelo uso de materiais típicos (LEMOS, 2010).

A categoria da Abordagem integrada pode ser relacionada com a multifuncionalidade e representa aquelas estratégias que fornecem respostas diversas nas funções que provê a cidade e seus sistemas.

No caso do planejamento é importante integrar a cidade com a região e a cidade com a natureza, entendendo para ambos os casos, que o planejamento deve tomar em conta a região pela possibilidade da mesma de suprir algumas necessidades da cidade como a provisão de alimentos, o acesso a terras para construção e acesso água potável, enquanto a região pode receber da cidade, novos mercados e clientes, e melhorar a infraestrutura e investimentos.

Segundo o UN-Habitat (2016) uma visão integrada é compatível com os pontos de vista de moradores, empregados, investidores, líderes e apenas com as decisões do governo nacional. Ao mesmo tempo é integrada porque procura misturar o uso da terra, oferta de emprego, educação, infraestrutura, cultura e recursos naturais, reduzindo assim o uso do veículo particular, e favorecendo o crescimento e desenvolvimento da urbanização nas áreas rurais ou suburbanas.

Para Litman (2015) o consumo per capita de terra aumenta entre 60-80\% e as viagens de veículo particular entre 20-60\%. Berg (1992) afirma que as cidades precisam ser concebidas como parte de sua bioregião, definindo o contexto para a sustentabilidade e uma maior autossuficiência, e as necessidades de sobrevivência

${ }^{6}$ LEMOS, M. Adaptação de cidades para mudança climática: Uma metodologia de análise para os planos diretores municipais, p.161 
humanas básicas de alimento, energia, e agua devem se ajustar com a capacidade da região para fornecer estes recursos.

Deste modo, olhar o ambiente é uma forma de integrar os ciclos urbanos com os ciclos naturais e evitar o rompimento dos mesmos com consequências negativas. Os referidos ciclos têm sido eliminados das mentes dos habitantes das cidades pela globalização e a noção de recursos ilimitados de todas partes mundiais, no entanto Daly (1997) considera que a ampla troca de recursos naturais é um problema e pode levar ao uso excessivo de recursos, esgotar a capacidade de regeneração e provisão de serviços a longo tempo.

Para Newman e Jennings (2012), as cidades precisam ser mais autotróficas e sintonizadas com a bioregião, suas entradas e saídas (inputs-outputs) e têm que estar mais perto das capacidades da região, ou seja, mais entradas teriam que ser locais de procedência perto da cidade e os resíduos teriam que ser reciclados em escalas locais e regionais. No mundo globalizado, o poder local e regional deve ser reforçado.

A regionalização trará o poder de volta para as comunidades regionais e facilitará a cooperação, dando maior equidade e oportunidades de saúde da região e de seus ecossistemas.

A Promoção da Diversidade compartilha com a categoria anterior a multifuncionalidade como estratégia de atuação dentro do planejamento, além da biodiversidade. Como citado por Wheeler (2002), sem diversidade o sistema urbano decai como sitio para viver, a uniformização das formas urbanas, usualmente produz paisagens monótonos, aumentando a segregação, as viagens de carro, os engarrafamentos e a poluição no ar.

A primeira diversidade promovida tem que ser a Biodiversidade, pois quando ela é entendida nas múltiplas funções e serviços essenciais dos ecossistemas, é mais provável que seja incluida nas polticas e projetos de planejamento urbano (AHERN et al., 2006).

Segundo a UNEP (2002), a biodiversidade contribui com uma grande quantidade de serviços ecossistêmicos, como a regulação da composição gasosa na atmosfera, a proteção das orlas, a regulação do ciclo hidrológico e climático, a geração e conservação da fertilidade nos solos, a dispersão e separação dos resíduos, a polinização das culturas e absorção de sustâncias poluentes, entre outros serviços. Da mesma forma fornece recursos genéticos para à agricultura 
que constitui a base da segurança alimentar mundial.

A cidade tem sido vista como um área com infraestrutura cinza (concreto, cimento asfalto e metais) e outra verde, locais naturais, separadas e diferenciadas; o interesee atual é integrar as plantas no tecido de infraestutura urbana, crescendo nos tetos e paredes, assim como dentro dos espaços. Esta arquitetura verde pode diminuir as ilhas de calor consideravelmente, proporcionando resfriamento aos prédios, ajudando na reciclagem da água e melhorando a qualidade do ar.

Os tetos verdes são ecossitemas construidos criados numa superficie impermeável, razão pela qual, a água escoa lentamente através do sistema e não rapidamente na superficie dura. Estas ferramentas da arquitetura moderna podem mitigar a mudança climática e reforçar os ecossitemas da região ao se convertir em refúgios para as aves (NEWMAN e JENNINGS, 2012).

A promoção da diversidade também faz referência à diversidade econômica e social. A primeira com a possibilidade de reduzir a sensibilidade da populacão urbana, através do fortalecimento das práticas empresarias locais, focada na construção de espaços comunitários e jardins com facilidade de deslocamentos de pedestres, moedas complementares que mantêm o dinheiro circulando no local, iniciativas de "preço real" com promoção das compras e consolidação das artes comunitárias.

A diversidade social, também deve considerar o planejamento, devido ao aumento da capacidade adaptativa dos cidadãos. Segundo o Ahern (2011), é importante que uma cidade seja diversa socialmente porque assim, pode suportar serviços sociais e programas culturais para manter a economia saudável e vibrante, assim como um local equitativo e atrativo para morar apesar dos distúrbios econômicos ou sociais que se possam apresentar.

A promoção da diversidade desde o planejamento, pode encorajar o respeito e aceitação das diferencias de classes, etnias, religiões e outros aspectos da vida humana e ao mesmo tempo, em termos de planejamento, pode significar um impulso para a compactação dos assentamentos urbanos, que liga a promoção da diversidade com a seguinte categoria, Reconhecimento dos limites, neste caso, os urbanos.

Nas últimas décadas e de acordo com uma pesquisa de Angel et al (2011), entre 1985 e 2000, a população da cidade de Accra capital da Gana têm crescido desde 
1.8 para 2.7 milhões de pessoas, $50 \%$ a mais, enquanto sua superfície urbana temse expandido desde 13,000 Há até 33,000 hectares, 153\% de aumento. Estes dados são exemplos das dinâmicas de expansão avaliadas nas cidades de países em desenvolvimento.

O UN-Hábitat (2016) argumenta que nas últimas décadas, nas áreas urbanas a perda de densidade e a expansão demográfica andam juntas. A densidade menor nas cidades causa o aumento nos custos da infraestrutura, piora a mobilidade, e destrói o solo para agricultura, muitas cidades têm se expandido sem arruamentos urbanos adequados e com integração deficiente.

Nesse sentido planejar a expansão das cidades é uma ferramenta poderosa de mudança que pode ajudar às autoridades públicas a oferecer uma resposta mais ordenada aos projetos de crescimento urbano. Caso contrário, as cidades podem continuar no seu caminho de expansão através de padrões de uso da terra ineficientes com o correspondente aumento no consumo de energia.

Nesta categoria, além do estabelecimento de limites no território, é importante planejar os limites na densidade populacional, considerando a relação direta com a exploração de recursos e o consumo de energia, materiais e espaço para construção de habitações, transporte e infraestrutura urbana.

Jabareen (2011) descreveu que o aumento das ilhas de calor, a diminuição das opções de retenção da água pelas superfícies, e as implicações na flexibilidade devido à presença de capital de grande valor podem dificultar os processos de renovação.

Lemos (2010) afirma que:

\begin{abstract}
"A definição de limites, entretanto, inserida em processos sustentáveis de planejamento, precisa atender ao princípio da implantação de densidades equilibradas, ou densidades possíveis, que aceitem os limites ecológicos e espaciais dos lugares nas redes (ecológicas, sociais, econômicas, físicoterritoriais) onde se inserem e os limites das características culturais que serão balizadores sociais importantes para a aceitação desses limites."
\end{abstract}

(Lemos, 2010) $)^{7}$

Outa categoria a ser analisada é a Temática setorial para a sustentabilidade, no

${ }^{7}$ LEMOS, M. Adaptação de cidades para mudança climática: Uma metodologia de análise para os planos diretores municipais, p.120 
qual se inclui como uma nova subcategoria da metodologia de avaliação, a agricultura urbana por considerar a segurança alimentar como uma qualidade chave de cidades que procuram construir resiliência e sustentabilidade ao longo do tempo; enquanto à agricultura urbana Hopkins (2000) descreve que o desenvolvimento biointensivo de jardinagem nos Estados Unidos tem rendimentos de duas a dezesseis vezes maiores do que os níveis comerciais mecanizados.

A agricultura urbana, caracterizada pela inovação e adaptação com as necessidades urbanas, inclui algumas inovações, como micro hortas que podem fornecer uma fonte de alimentos durante emergências ou desastres; ou como os tetos produtivos, que representam uma adaptação do entorno construído aos impactos da mudança climática; o estabelecimento de zonas verdes com plantio de árvores para melhorar a qualidade do ar e também contribuir na captura de água de chuva reduzindo a possibilidade de inundações ou escoamento superficial.

Segundo Dubbeling et al (2009), a agricultura urbana pode evitar que terras ambientalmente sensíveis ou perigosas sejam usadas como assentamentos ilegais.

Moreno e Flores (2007) destaca que é inegável, o aporte à qualidade da paisagem, transformando espaços degradados em cenários produtivos e de recreação orientados à comunidade urbana, criando espaços de interação social num entorno de trabalho e lazer.

Hopkins (2000) admite que a agricultura urbana provavelmente não será suficiente para satisfazer as necessidades de todos os habitantes, mas que pode ser uma ferramenta de construção de várias ligações entre cidade e área rural, podendo incluir a agricultura comunitária, mercados para agricultores, cooperativas de consumidores, entre outros, o que pode significar uma melhora na capacidade adaptativa das comunidades.

Outra subcategoria é Acessibilidade e mobilidade sustentável. Na cidade resiliente e sustentável o planejamento encoraja a mobilidade alternativa e prevê múltiplas opções, enfocando-a nas pessoas.

O consumo energético depende da distância de viagens, do modal e das variáveis de conexão com os padrões de mobilidade (CAMAGNI et al, 2002). A mobilidades urbana deve procurar maximizar as interações sociais positivas e minimizar o uso de energia e terra, através da construção de espaços públicos mais seguros, com facilidade para caminhar, com transporte público baixo em emissões e uso de energias e combustíveis alternativos, com sistemas que sejam 
de fácil acesso para todas as pessoas; o planejamento também deve promover a redução dos engarrafamentos, das viagens e o encorajamento de viagens não motorizadas, priorizando o uso da bicicleta e de car-sharing.

A subcategoria Acesso à habitação é uma temática relevante considerando que as necessidades habitacionais representam mais do $70 \%$ do uso da terra na maioria das cidades e determina a forma e densidade das mesmas, da mesma maneira gera emprego e contribui ao crescimento. Essa situação dá uma grande relevância às políticas habitacionais, pois os contextos inapropriados causam inequidade e desenvolvimento ineficiente da terra. Tomando em conta que processos migratórios acontecerão das áreas rurais para as cidades, muitos amplificados pela mudança climática (UN-Habitat, 2016).

Segundo Black et al (2011) um planejamento urbano focado nas necessidades de aqueles novos habitantes (migrantes) deve existir. Outros aspectos positivos de uma regulamentação adequada são a possibilidade de progresso em dois aspectos da resiliência urbana: reduz a sensibilidade dos habitantes ao melhorar as condições de moradia e o estado das construções e áreas de localização de aquelas construções, enquanto aumenta sua capacidade adaptativa basicamente pelas mesmas razoes de melhoramento das condições, assim como a criação de comunidades mais fortes e consolidadas que originam um tecido social robusto e uma comunidade mais profundamente enraizada.

Neste contexto de políticas habitacionais, é importante definir os aspectos de organização e os possíveis locais onde a infraestrutura pode ser construída, juntamente com as políticas que definem, fortalecem e impulsionem aquelas construções com boas práticas, uso de materiais mais amigáveis com o ambiente, procura de materiais com baixa emissão de GEE ou materiais orgânicos e construções que sejam funcionais e aproveitem as condições ambientais para a redução de consumo energético no aquecimento ou enfreamento.

O propósito das políticas habitacionais deve fornecer casas para as pessoas em uma cidade resiliente, onde as políticas vão colocar as pessoas e os direitos humanos na frente do desenvolvimento urbano.

Segundo o Lemos (2010), uma cidade sustentável procura melhorar a saúde dos habitantes e do ambiente, compreendendo a relação intrínseca entre eles, por sua vez facilita a segurança física e psicológica, reforçando a relação das pessoas com o lugar, promovendo a noção de pertencimento, através da criação de um 
ambiente de segurança. Todos estes aspectos devem considerar a avaliação das políticas de planejamento.

Como foi definido pela Avaliação Ecossistêmica do Milênio (2005):

\begin{abstract}
"O bem-estar humano tem múltiplos constituintes, incluindo o material básico para a boa vida, como um seguro e adequado sustento, suficiente comida o tempo tudo, refugio, roupas, e acesso a bens e serviços; saúde, incluindo sentir-se bem e ter um ambiente físico saudável, o seja ar limpo e acesso a agua potável."
\end{abstract}

(Avaliação Ecossistêmica do Milênio, 2005) ${ }^{8}$.

Nesse sentido, um planejamento baseado na melhoria dessas condições físicas, na redução da poluição e na garantia da provisão de água potável para os habitantes, assim como na participação da população durante a construção de políticas exemplifica o esforço público na construção de resiliência e sustentabilidade, fortalecendo a autonomia das comunidades.

A política de planejamento destinada a combater a pobreza deve ser reconhecida como um empenho público na construção de resiliência e sustentabilidade. Certos contextos legislativos podem criar marcos estáveis e previsíveis nas ações, tanto do setor público quanto do setor privado, garantindo a inclusão dos interesses dos grupos vulneráveis e ao mesmo tempo melhorando a qualidade de vida de milhões de pessoas (UN-HABITAT, 2016), considerando os bens econômicos, recursos capitais, necessidades financeiras, riqueza ou pobreza, as condições econômicas de nações e grupos claramente são determinantes da capacidade adaptativa (KATES, 2000), razão pela qual, as ações orientadas na direção de fortalecer a economia dos mais vulneráveis terão efeitos positivos na ampliação da capacidade adaptativa, na redução da sensibilidade e da exposição.

O efeito da mudança climática, principalmente para a população mais carente, denota a responsabilidade dos governos definirem políticas que gerem segurança e estabilidade para os grupos com mais autonomia na tomada de decisões.

O planejamento atual e futuro deve considerar todos os referidos aspectos e deve buscar um equilíbrio para cada um deles ao mesmo tempo que liga cada aspecto da estrutura urbana e tem consequências na construção de resiliência.

${ }^{8}$ WORLD RESOURCES INSTITUTE, Millennium Ecosystem Assessment Ecosystems and Human Well Being, p. Sec1:XIV 
O desafio é enorme porque na concepção atual, as políticas setoriais trabalham paralelamente, mas individualmente, e no planejamento passado não considerava pontos comuns.

Atualmente, é notório que o planejamento urbano deve considerar conjuntamente as soluções de modo inovador, incluindo os pensamentos e as necessidades das comunidades, principalmente daquelas mais vulneráveis e excluídas para obter um ambiente de participação e governança que garanta o bem-estar, a distribuição justa dos equipamentos e as oportunidades que permitam o direito à cidade para todos os habitantes.

No próximo capítulo são abordadas as novas concepções de planejamento de cidades, considerando a ameaça da mudança climática como um novo fator determinante, com responsabilidade de oferecer alternativas em ambientes desconhecidos pela maioria dos especialistas e dos governos em que a participação das comunidades no planejamento e desenvolvimento dos referidos planos deve ser mais significativa e preponderante do que no passado. 


\title{
4 \\ Mecanismos legais de controle do planejamento urbano na Colômbia
}

\begin{abstract}
“Os planos territoriais e urbanos precisam ser urgentemente revisados e atualizados, fornecendo adequadas medidas para o correto uso da terra começando pela redução no consumo do solo. A inovação é fundamental para implementar resiliência nas políticas territoriais, especialmente se esta é transferida aos grupos de interesse claves (quem elaboram as políticas, prefeituras, comunidades e cidadãos) os quais têm que ser educados em ações específicas."
\end{abstract}

(Attolico, 2014)

De acordo com Friend, et al (2013) a literatura profissional da resiliência climática urbana tem prestado menor atenção à cidade e a urbanização como sistemas e processos sócio-ecológicos-políticos complexos, dirigidos por forças econômicas e sociais que remodelam as paisagens naturais, formas de produção, troca e distribuição, relações sociais e distribuições diferenciais de poder e conhecimento, essa falta de atenção da complexidade e das relações tem criado vazios que o planejamento deve começar a resolver desde novas perspectivas.

Segundo Attolico (2014), apesar dos altos investimentos na redução da vulnerabilidade do ambiente construído, a estrutura urbana está se mostrando inadequada para lidar com os desastres naturais e a mudança climática.

Birkman (2014) aponta a necessidade de diferenciar os documentos de planejamento e de implementação, concentrando-se particularmente no desenvolvimento dos diferentes níveis verticais de agências de planejamento.

A maioria das medidas de adaptação atual, à mudança climática são ajustes físicos, como a construção de diques, modernização de edifícios, entre outros, enquanto falta dar ênfase aos aspectos institucionais e aos processos de transformação administrativa, politica, demográfica ou econômica que acontecem paralelamente (BIRKMAN, 2010).

${ }^{9}$ ATTOLICO, A. Building Resilience through Territorial Planning: The Experience of Province of Potenza, p. 530 
Fuchs (2011) afirma que a mudança de pensamento deve ter dois aspectos primordiais:

"1. A identificação de riscos de acima para abaixo deve ser trocada por uma construção de identificação de vulnerabilidades socioeconômicos de abaixo para acima.

2. Dar-se uma maior ênfase ao planejamento espacial, melhoramento das capacidades humanas (fortalecimento da governança) e institucionais, assim como novas ferramentas de planejamento, em lugar da proteção da infraestrutura física como único recurso de atuação..”

Fuchs $(2011)^{10}$

Nesse aspecto umas leis de boas qualidades devem promover a inclusão dos grupos vulneráveis, contribuindo ao alívio da pobreza e à promoção da coesão social (UN-HABITAT, 2016).

Os governos devem promover marcos legais e institucionais que permitam mobilizar recursos na construção de refúgios sustentáveis nos assentamentos humanos.

A seguir, será efetuada uma caracterização atual da Cidade de Bogotá, com descrição do processo legal de construção do ordenamento territorial na Colômbia, apontando as motivações da revisão do POT realizada em 2013, ocasionada pela mudança climática que propiciou um clima atípico e fortes eventos pluviométricos que provocaram o colapso da cidade, causando numerosos danos materiais e demostraram a falta de preparação, a baixa resiliência da cidade e a fragilidade de resposta para atender a estes eventos.

\section{1.}

\section{Ordenamento territorial na Colômbia}

$\mathrm{Na}$ busca das diretrizes que envolvem todos os aspectos a serem considerados na organização da cidade surge o conceito de ordenamento territorial que inclui o

${ }^{10}$ FUCHS, R., CONRAN, M., LOUIS, E. Climate change and Asia's coastal urban cities: can they meet the challenge? p. 16. 
planejamento urbano e com ele a ideia de Plano Diretor.

A legislação da Colômbia, define o ordenamento territorial como:

\begin{abstract}
“É um instrumento de planejamento e gestão das entidades territoriais e um processo de construção coletiva do país, (......), facilitando o desenvolvimento institucional, o fortalecimento da identidade cultural e o desenvolvimento territorial, entendido como desenvolvimento economicamente competitivo, socialmente justo, ambientalmente e fiscalmente sustentável, regionalmente harmônico, culturalmente pertinente, atendendo à diversidade cultural e físico-geográfica da Colômbia”.
\end{abstract}

$(\text { COLOMBIA, 2011) })^{11}$

Nessa descrição, o conceito envolve todo o território nacional e destaca-se os objetivos de sustentabilidade, participação e inclusão, fornecendo condições para garantir a resiliência dos territórios.

Desde a concepção macro planejamento territorial esta pesquisa se transporta ao plano municipal, nosso caso particular ao planejamento urbano (Plano Diretor) que segundo Oliveira (2004) adota o conceito de Meirelles (1993) definindo o complexo de normas legais e diretrizes técnicas para o desenvolvimento global e constante do município, sob os aspectos físico, social, econômico e administrativo, desejado pela comunidade local. Por outro lado, na legislação colombiana o equivalente ao Plano Diretor brasileiro é o Plano de Ordenamento Territorial (POT) é definido como o conjunto de objetivos, orientações, políticas, estratégias, metas, programas, atuações e normas adotadas para orientar e administrar o desenvolvimento físico do território e a utilização do solo (COLOMBIA, 1997).

Bogotá, foi afetada por uma forte temporada de chuvas nos anos de 2010 e 2011, o que ocasionou o colapso de mobilidade, inundações em áreas de habitação de baixa renda, perdas materiais, processos de remoção de terra e a falta de mecanismos administrativos para responder à ocorrências atípicas.

Observando a dinâmica da cidade e seu crescimento, assim como esta situação de clima extremo, a prefeitura e os organismos de planejamento e organização da

\footnotetext{
${ }^{11}$ Lei 1454 de 28 de Junho de 2011. Art. 2
} 
cidade tomaram a decisão de repensar o POT procurando reestruturá-lo, mudando seus objetivos e incluindo novas ideias como a gestão de riscos e a adaptação à mudança climática ao ordenamento territorial, conforme as considerações do Decreto n. 364/2013.

A seguir é efetuada a descrição do POT de Bogotá com explanação das principais razões de revisão e uma breve exposição dos desafios que devem ser considerados no seu planejamento urbano, com o destaque da importância estratégica da cidade na Economia nacional e seus problemas ambientais.

\section{2.}

\section{Plano de ordenamento territorial da cidade de Bogotá}

A cidade de Bogotá, como qualquer outra cidade de latino-américa tem experimentado um crescimento acelerado e a consequente redução ou alteração da qualidade dos recursos ambientais, a complicação em questões de mobilidade o aumento da população e da demanda de habitações com qualidade para esses novos habitantes, assim como os serviços públicos para as novas moradias.

No Mapa 1 pode ser observada a expansão nos últimos 50 anos do século XX.

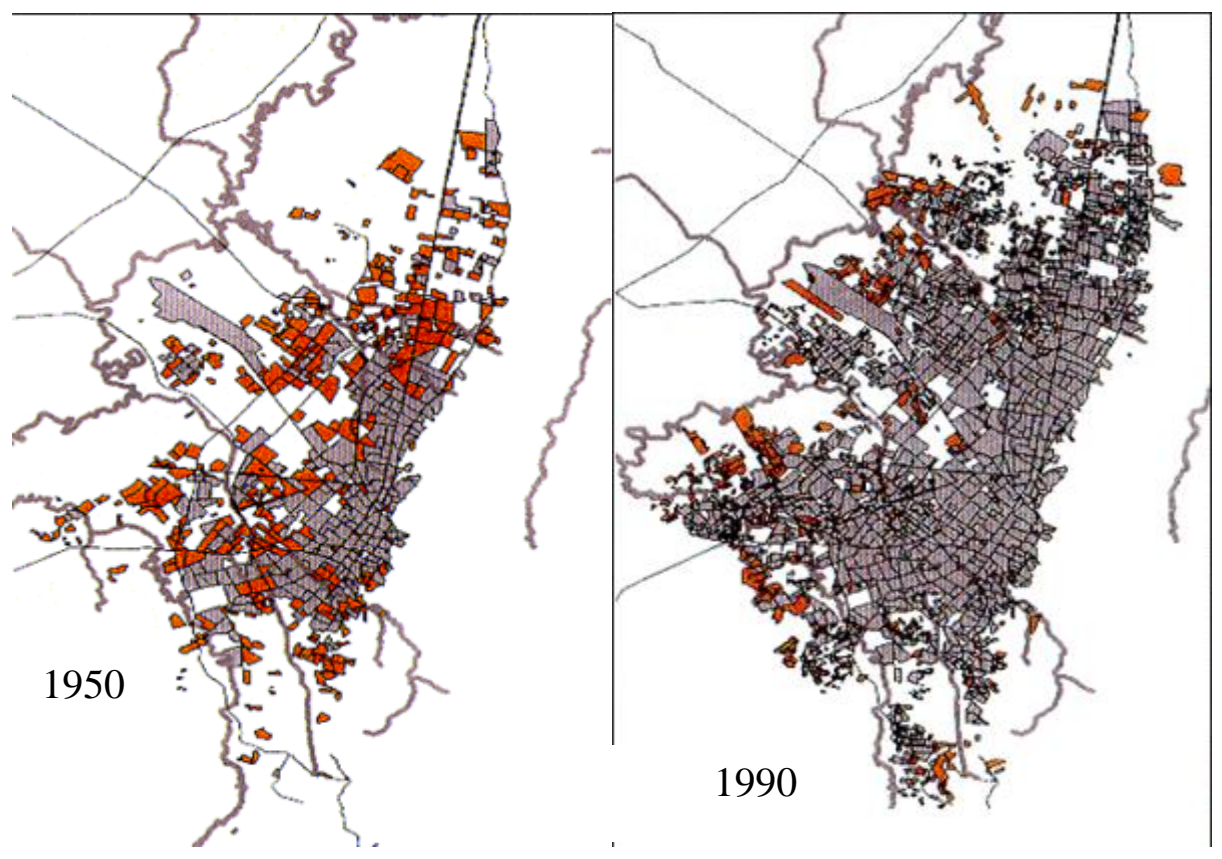

Fonte: Instituto de estudos urbanos IEU, Universidade Nacional

Mapa 1 - Expansão urbana de Bogotá entre 1950 e 1990. 
A urbanização, legal e ilegal, tem destruído ecossistemas críticos para a estabilidade ecológica e hidrológica nas áreas urbanas, desde os morros orientais até as áreas húmidas. A poluição no ar, principalmente por material particulado, é um dos maiores problemas relacionados ao aumento de doenças e à redução da qualidade de vida para os habitantes.

A seguir são descritos alguns fatores e indicadores da situação atual e das bases que motivaram a mudança do plano de ordenamento territorial.

- Aspectos demográficos

No relatório técnico do POT, a SDP da cidade ressalta a aceleração do processo de transição demográfica da cidade. No ano de 2012 a população de Bogotá era de 7.571 .345 pessoas distribuídas em 3.653 .868 (48,3\%) homens e 3.917.477 mulheres $(51,7 \%)$. A taxa de crescimento médio anual da população entre 2005 e 2012 foi de 1,45\%, e estima-se que entre 2012 e 2020 o crescimento populacional atinja o valor de 8.380 .801 pessoas.

Adicionalmente população de Bogotá está envelhecendo, pois a faixa etária acima de 60 anos já supera 10,3\% do total de habitantes (DANE, 2013) entre outros indicadores demográficos que tem reduzido a mortalidade infantil e tem aumentado a expectativa de vida.

Outro aspecto demográfico importante é a migração à cidade gerada pelo deslocamento do conflito armado que tem convertido Bogotá na principal receptora de refugiados, registrando-se mais de 325.000 pessoas. Como resultado, o centro urbano de Bogotá tem uma das maiores densidades populacionais do mundo com 13500 habitantes/Km² (MAYORS, 2007).

O Mapa 2, denominado Densidade urbana por localidade, apresentada a densidade urbana por localidade (organização administrativa) (DANE, 2007). 


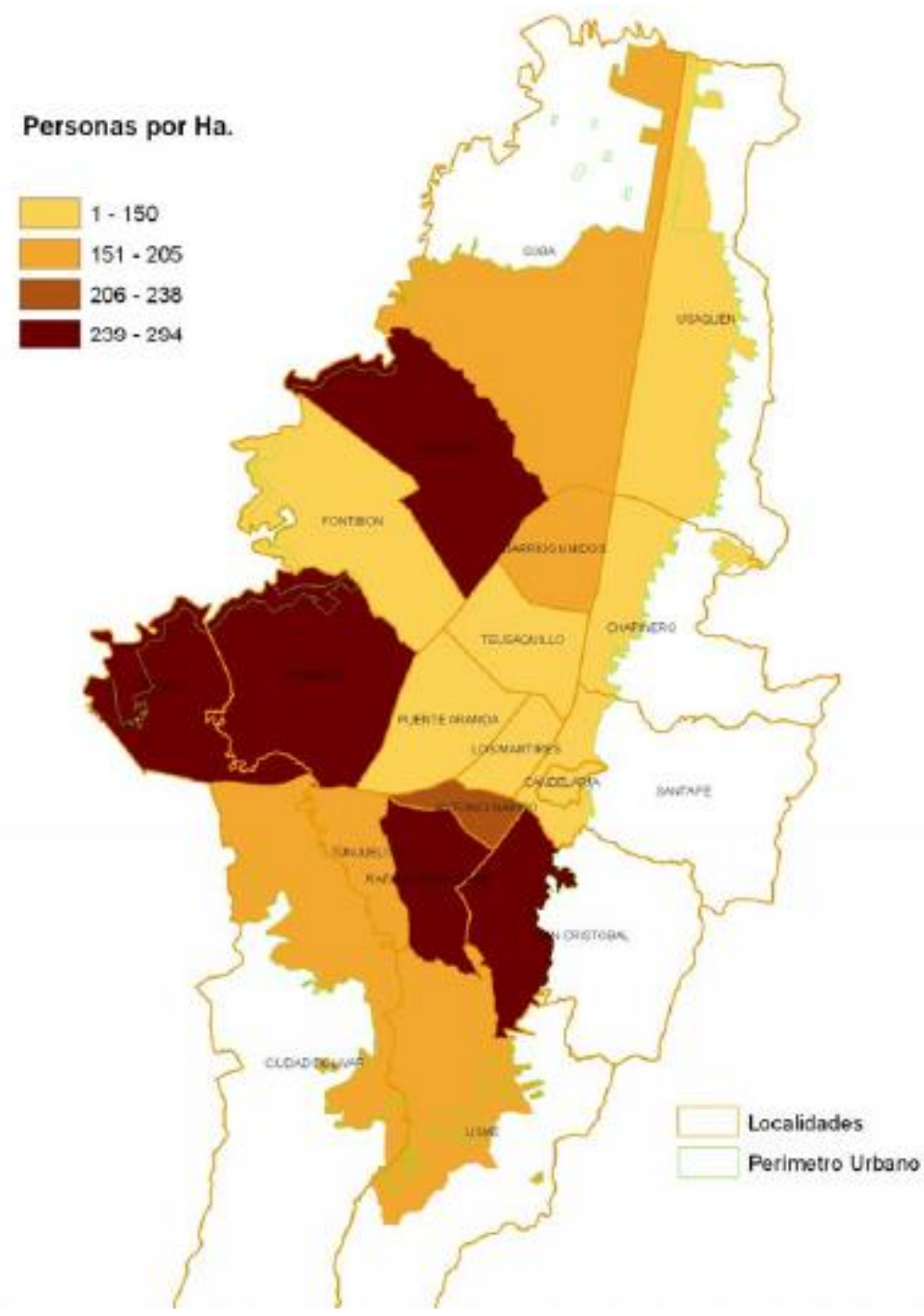

Mapa 2 - Densidade urbana por localidade, ano de 2010.

- Aspectos da gestão do risco

Após a situação de emergência registrada em 2010 e 2011, o planejamento em busca de proteção e prevenção, pretende gerir as áreas de alta sensibilidade e limitar a construção e o desenvolvimento das mesmas para reduzir a possibilidade de ocupação pela população vulnerável.

O Mapa 3, denominado Ameaça de alagamento pelo transbordamento do Rio Bogotá, apresenta as áreas susceptíveis aos alagamentos. 


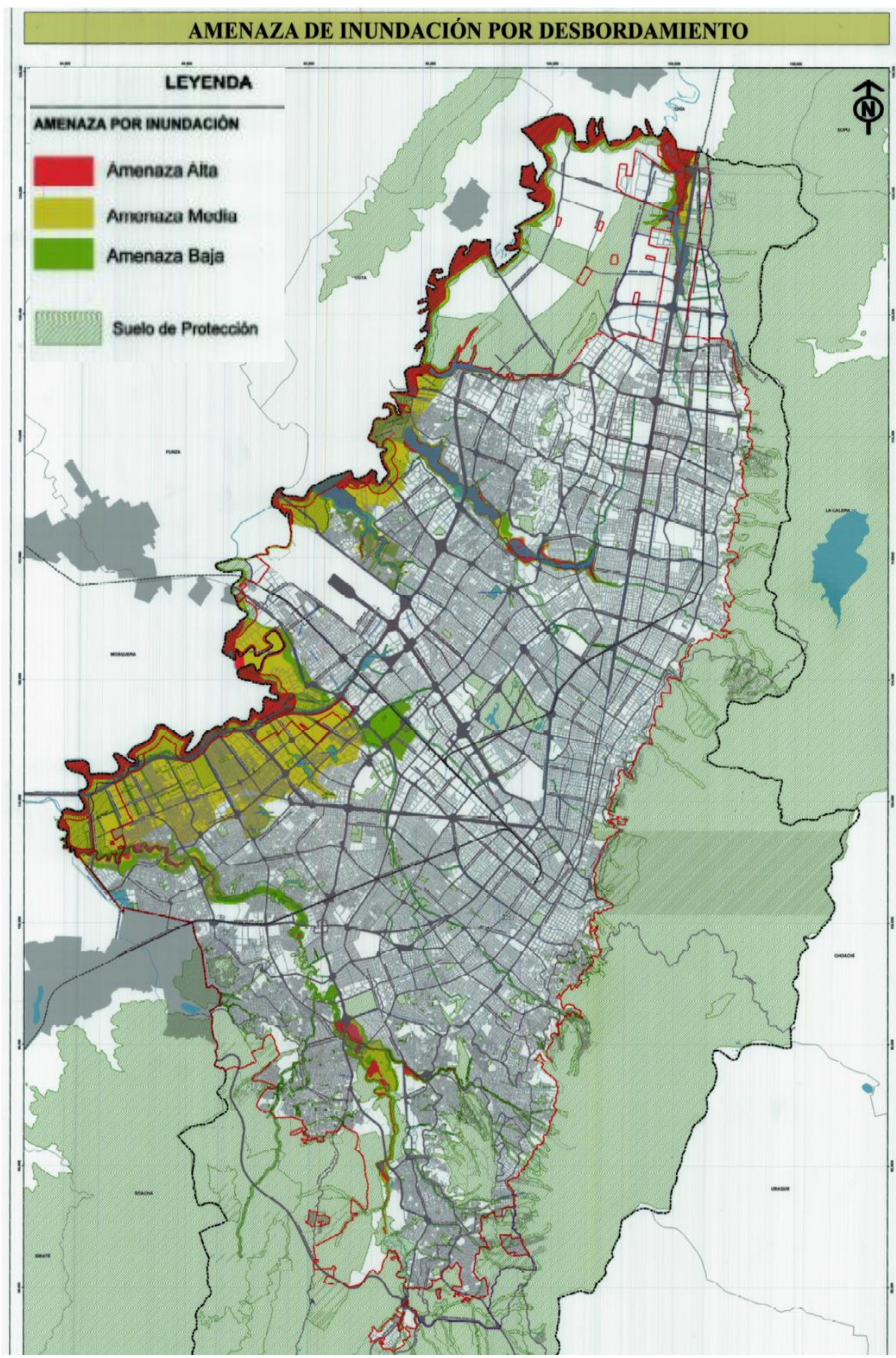

Fonte: Prefeitura Maior de Bogotá, 2013

Mapa 3. Ameaça de alagamento pelo transbordamento do rio Bogotá

Outro aspecto relacionado aos riscos refere-se ao deslizamento de terra. No caso de Bogotá, as localidades mais vulneráveis aos riscos de alagamentos e deslizamentos de terra, coincidem com as localidades que apresentam maiores índices de pobreza e densidade populacional, como as cidades de Bosa, Kennedy, Engativá, Fontibón, Suba, Tunjuelito e Rafael Uribe Uribe, Usme, Ciudad Bolívar e San Cristóbal (IDEAM et al, 2014). 
O Mapa 4 apresenta a Ameaça pelos fenômenos de deslizamento de terra e exemplifica a referida vulnerabilidade.

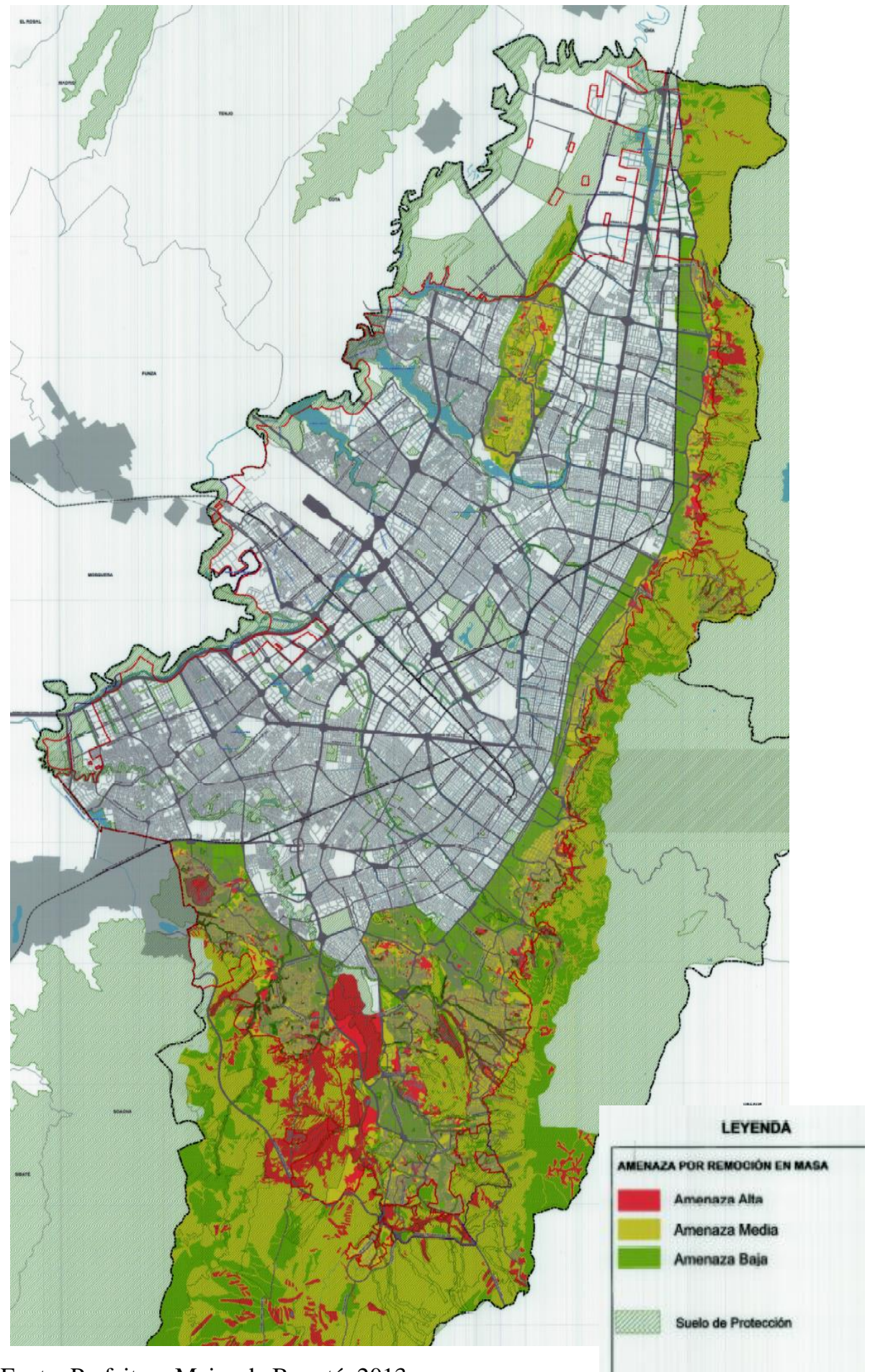

Fonte: Prefeitura Maior de Bogotá, 2013

Mapa 4. Ameaça pelos deslizamentos de terra na Bogotá

A Cidade de Bogotá é atingida frequentemente por eventos extremos, razão pela qual é importante observar outras experiências de planejamento urbano de 
cidades com os mesmos problemas, Birkmann et al (2014) comenta que é necessário revisar continuamente os planos espaciais, com inserção dos estudos recentes e atualizados para que o planejamento seja efetuado com base em processos prévios.

- Aspectos habitacionais e de equipamentos

O crescimento urbano informal é uma das manifestações mais impactantes nas transformações das estruturas sociais, econômicas, espaciais e ambientais nas escalas local, regional e nacional nos países onde estes processos se apresentam (HERRERA, 2009).

Nas cidades colombianas, incluindo Bogotá, o crescimento desordenado é muito comum pelas condições de pobreza e desigualdade dos habitantes, é difícil o acesso aos espaços mais valorizados da cidade que geralmente são reservados para pessoas de alta renda ou para prédios comercias e empresariais.

A cidade tem 1.895.960 moradias para satisfazer as necessidades de 1.978.528 habitações, isso significa que existe um déficit quantitativo de 145.822 unidades, por outro lado há o déficit qualitativo, 162.124 moradias presentam deficiências, como carências em serviços públicos domiciliários, superlotado o alguma combinação destes (PREFEITURA DE BOGOTÁ, 2007). No seu plano, as propostas são desenvolvidas com o objetivo de melhorar as condições de moradia dos habitantes mais vulneráveis.

O Mapa 5, denominado de Programa de Melhoramento Integral, representa graficamente as áreas objeto de intervenção conforme o déficit habitacional. 


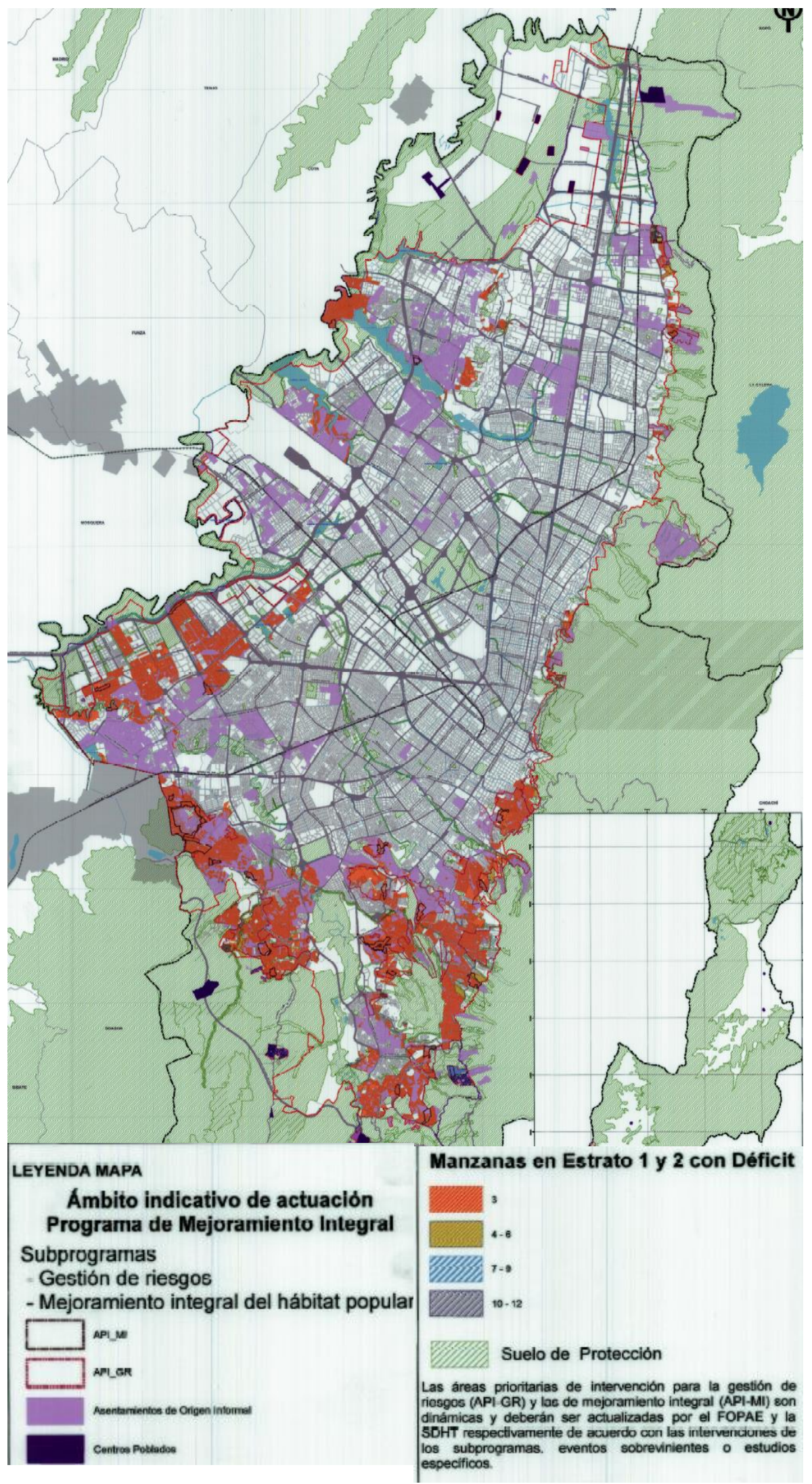

Fonte: Prefeitura Maior de Bogotá, 2013

Mapa 5 - Programa de Melhoramento Integral Habitacional 
No desenvolvimento de soluções habitacionais para famílias carentes, é necessário que os princípios de sustentabilidade sejam aplicáveis e seu desenvolvimento construtivo e espacial sejam efetuados em localização adequada, em um terreno com condições de solo servido que não afete a dinâmica do meio ambiente.

A acessibilidade da moradia aumenta a capacidade adaptativa das populações mais vulneráveis e evita a exclusão aos espaços e serviços, oferecidos pelo centro urbano.

O Mapa 6 apresenta a distribuição da área por metro quadrado $\left(\mathrm{m}^{2}\right)$ de solo conforme a disponibilidade de equipamentos por habitante, evidencia a desatenção na distribuição dos referidos equipamentos para as periferias da cidade e demonstra também a coincidência com as áreas de menor renda por habitante. Este diagnóstico permite apresentar a intenção da importância de implementar medidas que contribuam para o aumento da oferta de equipamentos nessas áreas desabastecidas, tornando-se assim um exemplo da distribuição justa da infraestrutura urbana. 


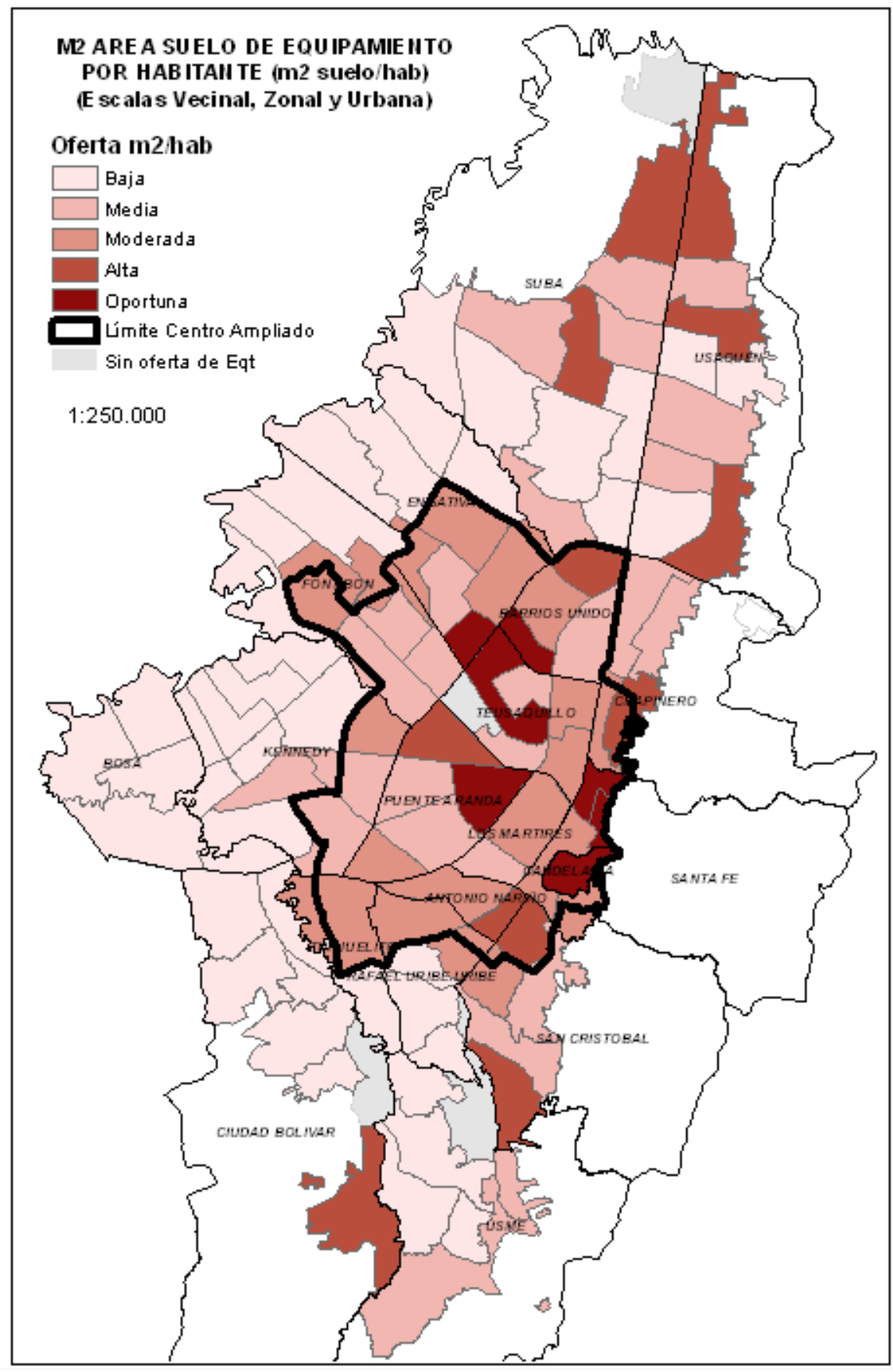

Fonte: Memoria justificativa mudança POT, 2013

Mapa 6 - Distribuição da área por metro quadrado $\left(\mathrm{m}^{2}\right)$ de solo por habitante.

- Aspectos de mobilidade

As estatísticas sobre o parque automotor demostram um aumento significativo nos últimos anos, principalmente no transporte particular, onde o número de automóveis foi de 695.415 em 2009 para 839.799 em 2011, e o número de motocicletas aumentou de 16.757 em 2009 para 269.452 em 2011 (PREFEITURA DE BOGOTÁ, 2011). 
Outras estatísticas da Prefeitura de Bogotá revelam que os usuários das classes sociais mais baixas representam os maiores tempos de viagem e que destinam cerca de $14 \%$ da sua renda para o transporte público, enquanto que nas classes superiores, destinam apenas $5 \%$.

Outro indicador, é a deterioração da mobilidade e o tempo médio de deslocamento das pessoas na Cidade de Bogotá que apenas entre os anos de 2003 e 2008 teve um aumento próximo aos 27\%, com um tempo médio adicional de 12,94 minutos nas viagens mais frequentes.

Na Figura 3 observa-se que embora tenha aumentado o número de veículos na Cidade de Bogotá e os quilômetros de vias não aumentaram com a mesma velocidade, o que representa um déficit na infraestrutura de mobilidade.

\begin{tabular}{|c|c|c|c|c|c|}
\hline Ano & Automóveis & População & Rodovias & $\begin{array}{c}\text { Taxa de } \\
\text { motorização x } \\
1000 \text { Hab. }\end{array}$ & $\begin{array}{c}\text { População/Km- } \\
\text { Faixa }\end{array}$ \\
\hline 2003 & 689.029 & 6.627 .568 & 15324 & 104 & 432 \\
\hline 2004 & 767.728 & 6.734 .041 & & 114 & \\
\hline 2005 & 838.647 & 6.840 .110 & & 123 & \\
\hline 2006 & 943.550 & 6.945 .216 & & 136 & \\
\hline 2007 & 1.062 .698 & 7.050 .228 & & 151 & \\
\hline 2008 & 1.168 .685 & 7.155 .052 & 15708 & 163 & 455 \\
\hline
\end{tabular}

Fonte: Adaptado Memoria justificativa mudanca POT, 2013, p. 34

Figura 3 - Parque autormotor e taxa de aumento de veiculos (2003 a 2007).

Por outro lado na Figura 4, apresenta o percentual de parque automotor versus o percentual de viagens atendidas e é possivel confirmar que o atendimiento da mobilidade pelas viagens do serviço público é mais eficiente em termos do uso de espaço ao requerer menos veículos para deslocar mais pessoas, porém, as viagens particulares representam o $90 \%$ das viagens feitas e atendem apenas $18 \%$ das viagens totais (DANE, 2013). 


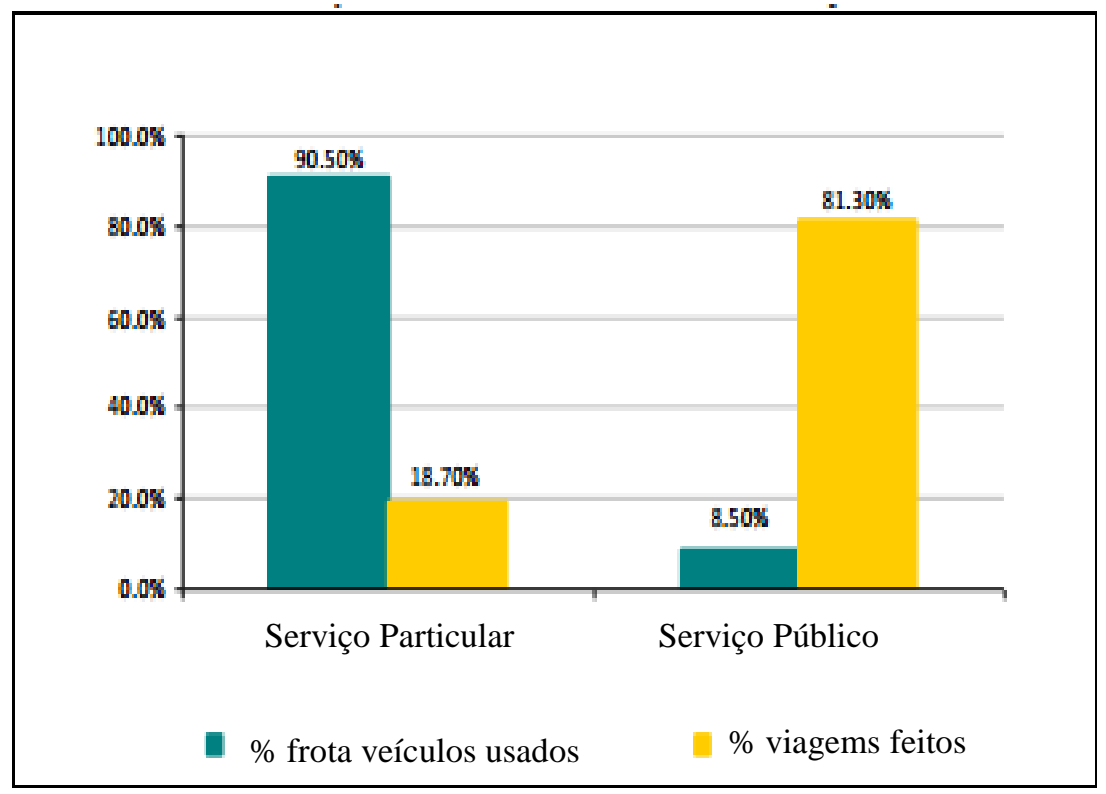

Fonte: Memoria justificativa mudanca POT, 2013, p. 36.

Figura 4 - Quantitativo do parque automotor versus viagens atendidas

- Aspectos ambientais

Como acontece com as grandes cidades do mundo na carreira do desenvolvimento, os espaços naturais têm tido que dar lugar aos espaços urbanos caracterizados pela impermeabilização do solo, a redução de zonas verdes, a canalização dos rios e outras fontes de água, o aumento da temperatura pelas chamadas ilhas de calor e a insuficiência na ventilação pelos patrões construtivos, os recursos naturais, especialmente água, ar, solo, ecossistemas e biodiversidade estão perdendo qualidade em Bogotá.

No caso da qualidade do ar, o material particulado é o poluente mais preocupante porque frequentemente ultrapassa os níveis máximos permissíveis determinados pelas normas colombianas (GAITÁN et al, 2007), por outro lado, as emissões de GEE de Bogotá, somente no ano de 2008 foram de 13,5 gigagramas de $\mathrm{CO}_{2}$ equivalentes (SDA, 2008).

A Figura 5, denominada Emissões de GEE, apresenta que as emissões em Bogotá no ano de 2008, estiveram associadas principalmente à produção e ao consumo de energia, ao tratamento de resíduos, processos industriais e agricultura. 


\begin{tabular}{|l|c|c|c|c|c|}
\hline \multirow{2}{*}{$\begin{array}{l}\text { Metodologia } \\
\text { IPCC 2006 }\end{array}$} & \multicolumn{5}{|c|}{ Toneladas emitidas em 2008 } \\
\cline { 2 - 6 } & $\mathrm{CO}_{2}$ & $\mathrm{CH}_{4}$ & $\mathrm{~N}_{2} \mathrm{O}$ & $\mathrm{COVNM}$ & $\mathrm{CO}_{2}$-eq \\
\hline 1. Energia & $7.760 .632,71$ & $5.291,52$ & 517,55 & & $8.032 .196,34$ \\
\hline $\begin{array}{l}\text { 2. Processos } \\
\text { industriais }\end{array}$ & $5.108,00$ & & & $4.619,00$ & $5.108,00$ \\
\hline $\begin{array}{l}\text { 3. Agricultura, } \\
\text { silvicultura e } \\
\text { outros usos do } \\
\text { solo }\end{array}$ & $9.189,00$ & $7.738,00$ & $7.486,00$ & & $2.492 .347,00$ \\
\hline 4. Resíduos & & $141.361,57$ & & & \\
\hline \multicolumn{1}{|c|}{ TOTAL } & $7.774 .929,71$ & $\mathbf{1 5 4 . 3 9 1 , 0 9}$ & $\mathbf{8 . 0 0 3 , 5 5}$ & $4.619,00$ & $\mathbf{1 3 . 4 9 8 . 2 4 4 , 3 1}$ \\
\hline
\end{tabular}

-Emissões em unidades de $\mathrm{CO}_{2}$-equivalente de acordo com o Potencial de Aquecimento Global de cada gas: $1 \mathrm{t} \mathrm{CO}_{2}=1 \mathrm{t}$ $\mathrm{CO}_{2}$ eq. $1 \mathrm{t} \mathrm{C \textrm {CH } _ { 4 }}=21 \mathrm{t} \mathrm{CO}$ eq. $1 \mathrm{t} \mathrm{N} \mathrm{N}_{2}=310 \mathrm{t} \mathrm{CO}_{2}$ eq.

Fonte: Adaptado SDA, 2008

Figura 5 - Emissões de GEE na Cidade de Bogotá (2008).

O transporte é uma das principais causas de emissões de poluentes na Cidade de Bogotá, razão que impulsionou a inserção dos aspectos ambientais nas mudanças da política encaminhadas para melhorar a eficiência e a concepção do sistema.

A Prefeitura de Bogotá registrou a evidência da mudança climática que afetou a capital:

\begin{abstract}
"Se encontrou a temperatura média do ar na Colômbia aumentará: $1,4^{\circ} \mathrm{C}$ para os anos 2011 - 2040; $2,4^{\circ} \mathrm{C}$ para 2041 - 2070 e $3,2^{\circ} \mathrm{C}$ para o período 2071 2100 na maior parte do território nacional. - Para a Savana de Bogotá os cenários da mudança climática com maior quantidade de emissões de GEE analisados, mostram reduções de chuva de: $-11.6 \%$ para o período 2011$2040 ;-16,1 \%$ para $2041-2070$ e do $-3,4 \%$ para $2071-2100$, com respeito à climatologia do período de referência 1971-2000."
\end{abstract}

(Bogotá, 2013) $)^{12}$

Segundo o IDEAM (2014), pela posição geográfica de Bogotá e de outros municípios é altamente dependente dos padrões climáticos na segurança do fornecimento da água (temperatura e precipitação), pois, todos os assentamentos estão localizados próximos das nascentes dos principais rios que fornecem o abastecimento de água.

\footnotetext{
${ }^{12}$ Prefeitura de Bogotá, Memoria justificativa/ documento resumen, p. 48
} 
A Figura 6 apresenta as fontes hídricas que abastecem os aquedutos da Cidade de Bogotá e adjacências. Essa situação gera uma incerteza adicional do abastecimento de água como elemento fundamental para a vida humana, por isso a importância de criar políticas e intervenções com o propósito de proteger os ecossistemas responsáveis pelo equilíbrio dos ciclos hídricos.

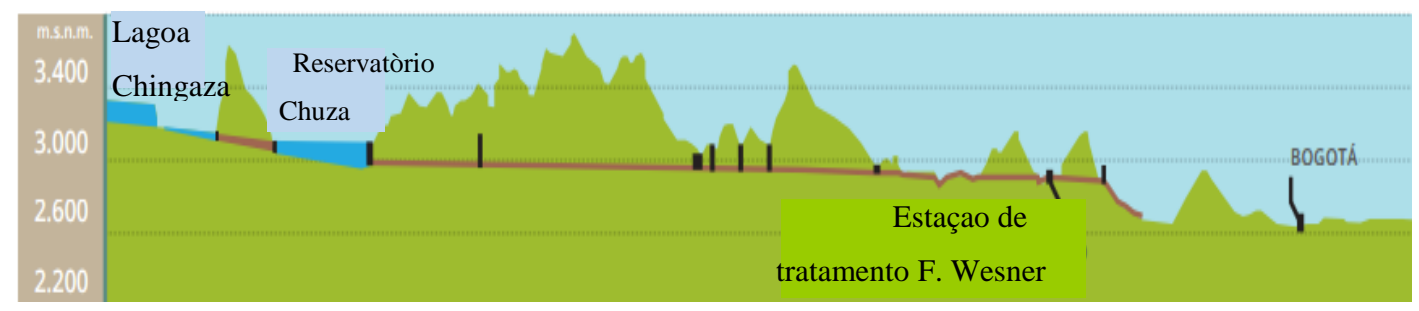

Fonte: PNUD.

Figura 6 - Fontes hídricas que abastecem a Cidade de Bogotá e adjacências.

Estas situações são vitais para o entendimento do compromisso do planejamento com a segurança de decisões que tenham resultados positivos com relação ao futuro da resiliência urbana, principalmente se a cidade já apresenta uma vulnerabilidade a eventos extremos do clima, conforme o ocorrido em 2010 e 2011, com a presença do fenómeno de La Niña.

O POT da Cidade de Bogotá pretende planejar a cidade, ao redor da estrutura ecológica principal, com uma rede de ecossistemas de diversas categorias que forneçam serviços ambientais relevantes para a cidade.

No Mapa 7, denominado de Estrutura ecológica principal urbana, são descritos os principais ecossistemas que compõem a estrutura e que são objeto de proteção. 


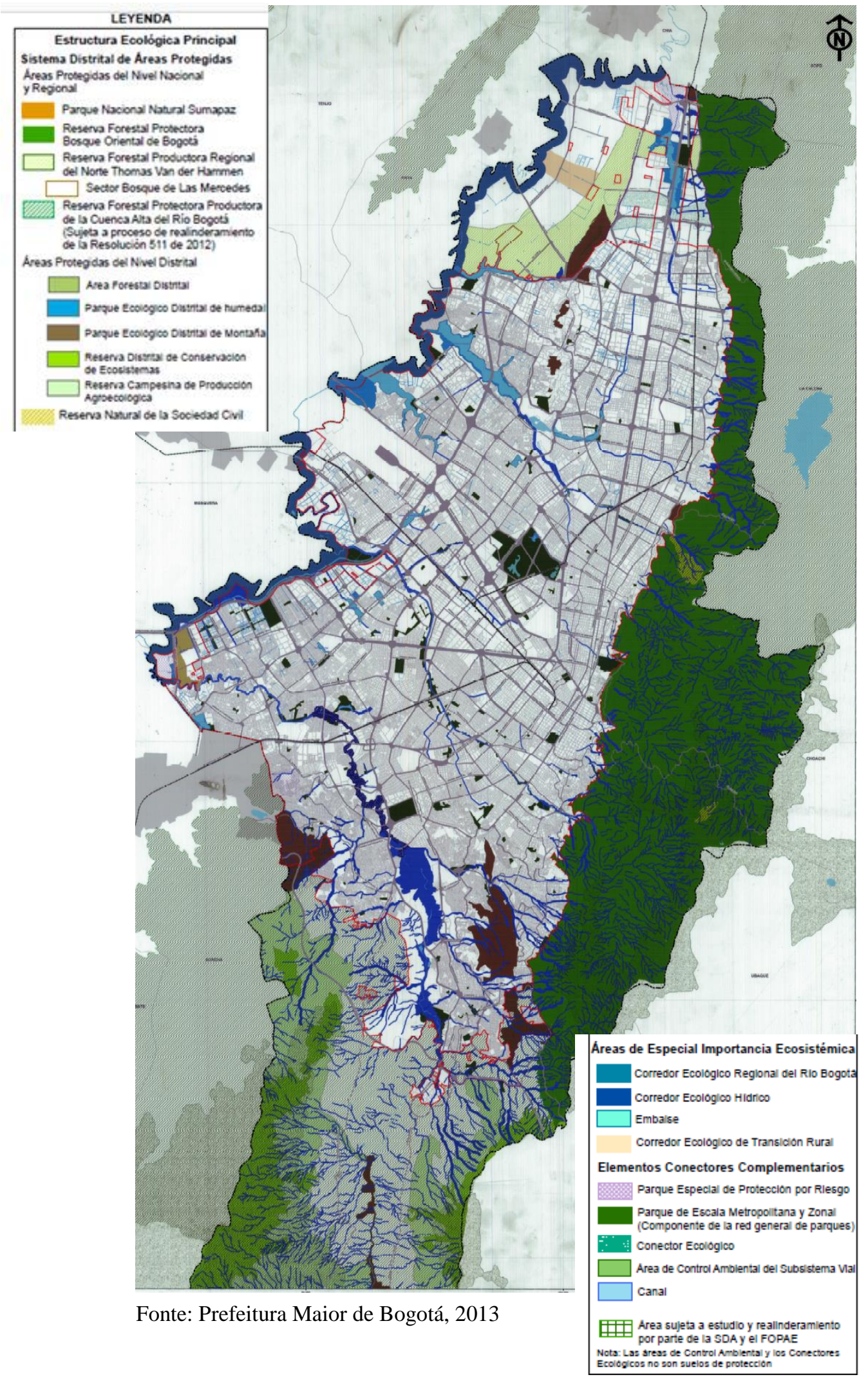

Mapa 7 - Estrutura Ecológica principal urbana.

- Aspectos da segurança alimentar 
Segundo as estatísticas da SDP (2011) 24,3\% da população de Bogotá se encontrava em condições de insegurança alimentar, nesse grupo, 0,9\% estava em condições severas, 5,2\% em condições moderadas e 18,2\% em condições leves. As localidades com maior incidência são Santa Fé, Bosa e Los Mártires.

O propósito da Prefeitura de Bogotá era manter e reforçar a oferta de alimentos verdes cultivados na região com ações como o aproveitamento da produção de alimentos da cidade principal e dos departamentos vizinhos, deste modo, defende a ruralidade, que representa o 75\% do território (BOGOTÁ, 2013).

Klein et al (2005) destaca que é esperado um planejamento contemporâneo compatível com as ações de resposta às demandas atuais, dentre elas a preparação das cidades para as consequências da mudança climática ou pelo menos mostrar sinais de adaptação de seus habitantes e da sua infraestrutura.

Os tomadores de decisões têm pouco incentivo para incorporar à adaptação na tomada de decisões porque a política e o mercado não encorajam o planejamento ao longo prazo e porque as responsabilidades pelas ações não estão claras.

Jabareen (2015) destacou que um componente crítico de resposta à questão é saber se as cidades estão enfrentando as mudanças climáticas de forma adequada, para isso deve ser efetuada uma avaliação completa das políticas urbanas de mitigação e adaptação, e verificar como eles são refletidos nos planos diretores.

Juntando as necessidades de revisão e reestruturação do novo plano de ordenamento territorial com as dificuldades estruturais e sociais atuais e futuras que a Cidade de Bogotá enfrentará por causa da mudança climática

A seguir é descrita a metodologia usada na avaliação qualitativa da tendência do POT na construção da resiliência e sustentabilidade para a Cidade de Bogotá. 


\section{5 \\ Metodologia de avaliação}

Esta pesquisa tem como objeto de estudo o Plano de Ordenamento Territorial (POT) da Cidade de Bogotá, avaliando como a sua contribuição e orientação poderá tornar a cidade mais resiliente e sustentável, com a premissa de que os Planos de Ordenamento são os documentos base do planejamento urbano para lidar com os problemas e desafios dos novos contextos de incerteza ambiental, instituídos pela mudança climática.

\section{1}

\section{Construção da metodologia ligando os conceitos de resiliência e sustentabilidade, conforme Lemos.}

Será utilizada a ferramenta metodológica proposta por Lemos (2010), com algumas variações definidas pela autora, na busca de avaliar o nível de contribuição e orientação de instrumentos de planejamento territorial (POT) para a adaptação e ampliação da resiliência urbana, atuando sobre a redução de vulnerabilidades socioambientais, em particular as socioclimáticas para enfrentar as ameaças naturais incidentes sobre o espaço urbano.

No caso da avaliação da contribuição com a resiliência, serão usadas as categorias de sustentabilidade e resiliência previamente descritas no Capítulo 3, considerando o potencial que estas ações terão ao mitigar, antecipar, reduzir a exposição, reduzir a sensibilidade ou aumentar a capacidade adaptativa diante os eventos extremos.

Além do proposto por Lemos (2010) sobre as categorias de sustentabilidade, essa pesquisa adicionou um item à proposta metodológica a inclusão dentro da categoria temáticas setoriais para a sustentabilidade, denominado de Segurança alimentar-Agricultura urbana.

Essa adaptação à metodologia é consequência das próprias ações propostas no Plano, reconhecido no POT como uma estratégia a ser aplicada na tendência à 
construção sustentável, como parte dos mecanismos para enfrentar as ilhas de calor e como estratégia para manter a segurança alimentar.

Foi desenvolvida uma breve descrição sobre os benefícios da implementação e foi realizado um diagnóstico da Cidade de Bogotá onde constam os indicadores que preocuparam o Governo Municipal pela insegurança alimentar.

O POT considera a cidade como um local de convergência econômica e social onde não deve existir segregação e sim inclusão. Este documento procura melhorar as condições populacionais, urbanas, rurais e ambientais, a partir de intervenções arquitetônicas e sociais sobre os espaços construídos que se encontram deteriorados ou que precisam de uma gestão adequada.

O Plano está dividido em três componentes: Componente Geral, Componente Urbano e Componente Rural.

Nessa pesquisa serão analisados os artigos dos dois primeiros componentes, o Geral e o Urbano, considerando que o componente geral já está baseado em uma visão conjunta da área urbana da Cidade de Bogotá, integrando o solo rural nos interesses do desenvolvimento e entendendo a importância da inclusão rural na gestão, entre outros aspectos, para a segurança alimentar da cidade e a preservação da estrutura ecológica, através do controle da expansão urbana.

A avaliação do exposto no componente geral é vital porque ele contém as políticas gerais para a cidade, as estratégias de ordenamento para a capital, a classificação do solo e especialmente um capítulo para a gestão de riscos e mudança climática.

Por outro lado, a avaliação do Título 2 ou Componente Urbano, vai atingir as consequências na resiliência dos lineamentos estratégicos dos sistemas que compõem o planejamento urbano (mobilidade, serviços públicos, espaço público construído, equipamentos, estrutura socioeconômica e espacial e o concernente às cargas urbanísticas).

Com os artigos dos referidos títulos, será construída inicialmente a matriz teste, que vai relacionar as orientações do POT que atendem a princípios de sustentabilidade, aos resultados previsíveis dessas orientações para a resiliência urbana.

O exemplo da Tabela 1 demonstra o raciocínio de cada artigo avaliado. Essa análise é efetuada para cada artigo do plano que apresenta restrições e orientações para a ação das entidades públicas no desenvolvimento urbano ou nas prioridades 
para aplicação de políticas setoriais com os impactos sobre a vulnerabilidade e resiliência (LEMOS, 2010).

O tema chave é a Agricultura Urbana, parte integrante das categorias de sustentabilidade, que abrange desde o ponto de vista da segurança alimentar, considerando que a expansão urbana tem repercussões no solo, que é destinado para culturas e semeadura de alimentos e as perdas de solo que torna o cultivo dos alimentos mais escassos ou mais caros, por sua vez, esta medida pode influenciar positivamente na poupança de dinheiro nos lares e reduzir as emissões de GEE, devido à redução de transporte por dispor os alimentos perto dos consumidores.

Tabela 1. Exemplo da matriz teste

\begin{tabular}{|c|c|c|c|c|c|}
\hline Item do POT & $\begin{array}{l}\text { Tema- } \\
\text { chave }\end{array}$ & $\begin{array}{c}\text { Categoria } \\
\text { sustentabilidade }\end{array}$ & $\begin{array}{l}\text { Contra } \\
\text { resiliência }\end{array}$ & $\begin{array}{c}\text { Pro } \\
\text { resiliência }\end{array}$ & Comentário \\
\hline $\begin{array}{l}\text { Art. 131. d. } \\
\text { Promoção e } \\
\text { diversificação } \\
\text { de hortas } \\
\text { urbanas que } \\
\text { contribuam à } \\
\text { diminuição } \\
\text { da } \\
\text { temperatura } \\
\text { e aportem à } \\
\text { segurança } \\
\text { alimentar. } \\
\text { (Bogotá, } \\
\text { 2013) }\end{array}$ & $\begin{array}{l}\text { Agricultura } \\
\text { urbana }\end{array}$ & $\begin{array}{c}\text { TEMÁTICAS } \\
\text { SETORIAIS PARA A } \\
\text { SUSTENTABILIDADE; }\end{array}$ & & $\begin{array}{l}\text { Capacidade } \\
\text { adaptativa, } \\
\text { mitigação, } \\
\text { sensibilidade }\end{array}$ & $\begin{array}{c}\text { Considerando } \\
\text { o fato de que } \\
\text { a expansão } \\
\text { urbana tem } \\
\text { repercussões } \\
\text { no solo que é } \\
\text { destinado } \\
\text { para culturas } \\
\text { e semeadura } \\
\text { de alimentos } \\
\text { e aquela } \\
\text { perdida faz } \\
\text { que os } \\
\text { alimentos } \\
\text { sejam } \\
\text { escassos ou } \\
\text { mais caros }\end{array}$ \\
\hline
\end{tabular}

Fonte: Adaptado de Lemos, 2010, p.173.

Após determinar a inter-relação entre as categorias de sustentabilidade e resiliência, será construída a matriz de análise de contribuição, no qual se estabelecem os resultados (padrões) esperados pela aplicação das ações instituídas no plano.

No caso das categorias de resiliência e análise de potencial é possível reconhecer que a medida exposta no artigo pode contribuir para a redução da sensibilidade e da exposição da região onde será implantada, razão pela qual está será avaliada com o mais um $(+1)$. 
Tabela 2. Padrões de relação entre categorias de sustentabilidade e resiliência

\begin{tabular}{|c|c|c|c|c|c|c|c|c|c|c|c|c|c|c|c|c|c|}
\hline \multirow{4}{*}{ Item do POT } & \multirow{4}{*}{$\begin{array}{l}\text { Categorias de } \\
\text { sustentabilidad } \\
\text { e }\end{array}$} & \multicolumn{16}{|c|}{ Categorias de resiliencia } \\
\hline & & \multicolumn{14}{|c|}{ Alcance dos resultados } & \multirow{2}{*}{\multicolumn{2}{|c|}{$\begin{array}{c}\text { Fatores } \\
\text { potencializadore } \\
\text { Abragencia } \\
\end{array}$}} \\
\hline & & \multicolumn{3}{|c|}{ Mitigacao } & \multicolumn{2}{|c|}{ Antecipacao } & \multicolumn{3}{|c|}{ Exposicao } & \multicolumn{3}{|c|}{ Sensibilidade } & \multicolumn{3}{|c|}{ Capacidade adaptativa } & & \\
\hline & & Mitiga & \begin{tabular}{|c} 
Nao \\
interfere
\end{tabular} & Emite & Antecipa & $\begin{array}{l}\text { Reage ou } \\
\text { naose }\end{array}$ & Reduz & $\begin{array}{c}\text { Nao } \\
\text { interfere }\end{array}$ & Amplia & Reduz & $\begin{array}{c}\text { Nao } \\
\text { interfere }\end{array}$ & Amplia & Reduz & $\begin{array}{c}\text { Nao } \\
\text { interfere }\end{array}$ & Amplia & $\begin{array}{c}\text { Mútiplos } \\
\text { fatores }\end{array}$ & $\begin{array}{l}\text { Único } \\
\text { fator }\end{array}$ \\
\hline $\begin{array}{l}\text { Art. 131. d. Promoção e } \\
\text { diversificação de hortas } \\
\text { urbanas que } \\
\text { contribuamà à } \\
\text { diminuição da } \\
\text { temperatura e aportem } \\
\text { à segurança alimentar. } \\
\text { (Bogotá, 2013) }\end{array}$ & \begin{tabular}{|c} 
TEMÁTICAS \\
SETORIAIS \\
PARAA \\
SUSTENTABILIDA \\
DE
\end{tabular} & 1 & & & & - & & - & & 1 & & & 1 & & & 1 & \\
\hline
\end{tabular}

Fonte: Elaboração própria baseada em Lemos, 2010, p. 186

As medidas que podem contribuir de maneira negativa na construção da resiliência urbana, como por exemplo, no aumento de emissões GEE, ou consumo de energia devem ser qualificadas com menos um (-1) na matriz anterior. Caso contrário, não têm nenhuma influência direta na resiliência ou no aumento da vulnerabilidade, serão marcadas com (NA) ou não aplicam na avaliação.

Este processo foi repetido para cada artigo (nas matrizes desenvolvidas pela metodologia) que continham uma atividade a ser executada.

$\mathrm{Na}$ seguinte fase da aplicação da metodologia ao POT, finalmente são anexados aos padrões de relação entre as categorias de sustentabilidade e resiliência, ou seja, aqueles aspectos que podem potencializar os efeitos positivos ou negativos no estabelecimento da resiliência urbana chamados de fatores multiplicadores (aspectos negativos relativos ao aumento das emissões e ampliação da exposição ou positivos como resultados significativos por trás das decisões).

Além disso, no caso dos artigos que contribuem de maneira positiva em mais de um dos componentes de vulnerabilidade e para a mitigação (como o item avaliado no exemplo) foi incluído o fator potencializador de abrangência.

Os outros fatores potencializadores, a associação de processos políticos de tomada de decisão, de gestão de recurso e planejamento de desenvolvimento, não foram avaliados nesta pesquisa, pois a avaliação está restrita aos aspectos relacionados à vulnerabilidade e não aos mecanismos de gestão impostos pela lei. 
O desenho final da matriz de análise de contribuição pode ser observado previamente na Figura 7, denominada Matriz de análise de contribuição, e detalhadamente no Apêndice A.

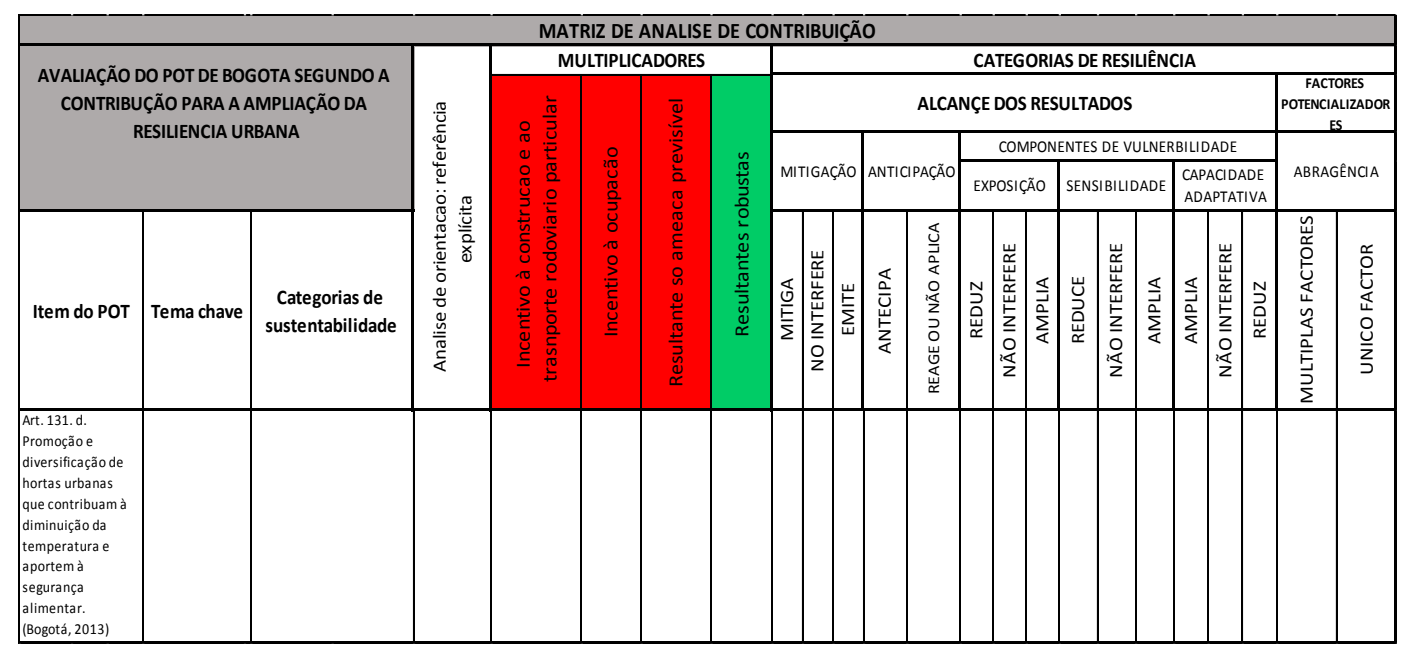

Fonte: Adaptado de Lemos, 2010, p. 186.

Figura 7. Matriz de análise de contribuição

As conclusões qualitativas desta avaliação permitirão conhecer a tendência da contribuição ou não do plano na construção da resiliência urbana da Cidade de Bogotá.

O POT se refere a necessidade de adaptação às ameaças climáticas:

"é preciso, no Plano de Ordenamento Territorial, a incorporação da variabilidade e a adaptação da mudança climática na gestão do risco, ao igual que em todos os temas que geram desenvolvimento no território e que, de uma ou outra forma, se podem ver afetadas por algum evento de desastre."

(Bogotá, 2013) $)^{13}$

Desde a concepção e estabelecimento do diagnostico, a gestão dos riscos associados à mudança climática foram consideradas e estão explícitas neste documento. Além disso, a gestão de riscos também é mencionada nos objetivos do plano, fazendo ênfase aos reassentamentos das famílias em locais de baixo risco; nas políticas do plano, no estabelecimento de solos de proteção para locais que

${ }^{13}$ BOGOTA (Município). Documento técnico de soporte. p. 259 
sejam definidos como de alto risco, além de ter um capitulo exclusivo à gestão de riscos e à mudança climática (Titulo I, capitulo VI) que inclui as definições, princípios, objetivos e ações específicas.

No final da pesquisa, será definido o enquadramento do POT da Cidade de Bogotá em qual das categorias, classificadas por Lemos (2010) para o grau de comprometimento dos instrumentos de planejamento com a resiliência, conforme exposto na Figura 8.

\begin{tabular}{r|l}
\hline 1 & Orientado com contribuições robustas \\
\hline 2 & Orientado com contribuições frágeis \\
\hline 3 & Não orientado com contribuições indiretas robustas \\
\hline 4 & Não orientado com contribuições indiretas frágeis \\
\hline 5 & Não orientado sem contribuição para o enfrentamento da mudança climática.
\end{tabular}

Fonte: Lemos, 2010, p. 190.

Figura 8 - Classificação do grau de comprometimento dos instrumentos de planejamento.

A avaliação permitirá classificar o POT, segundo as orientações e contribuições esperadas, e poderá ser utilizado como ferramenta na decisão de reforçar a política, no caso de fragilidade ou no caso de necessidade de desenvolvimento de outra opção para buscar soluções e alternativas às circunstâncias atuais. 


\section{6 \\ Processo de análise e classificação do POT conforme o grau de orientação e contribuição para a resiliência urbana.}

A análise é baseada no POT em função da mudança climática e dos mecanismos de resiliência, considerando as informações sobre vulnerabilidade e a redução da mesma, ameaças climáticas, assim como referências explicitas sobre à adaptação e ampliação da resiliência contida nos objetivos do plano.

\section{1.}

\section{Análise de orientação do POT}

A análise de orientação do plano é baseada nos principais documentos que integram o escopo da justificativa de modificação do plano, são eles: a $2^{\mathrm{a}}$. Comunicação Nacional preparatória para a Convenção Marco das Nações Unidas sobre a Mudança Climáticas, os estudos do IDEAM e os estudos da FOPAE (atual IDIGER), todos realizados após a temporada de chuvas atípicas de 2011, agravadas pelo fenômeno La Niña.

Todas as referidas razões demostram que o diagnóstico, base do plano, tem informações específicas sobre os riscos e a vulnerabilidades da Cidade de Bogotá.

Efetuada a análise dos estudos prévios foi observado se consta na lei o enfoque de adaptação e redução da vulnerabilidade, no Título I, Capítulo VI que trata da importância de considerar estas novas variáveis climáticas extremas e de adotar mecanismos para lidar com elas no marco de desenvolvimento e aumento populacional da Bogotá.

Algumas das medidas estabelecidas no Plano, fundamentadas em estudos prévios são a redução da vulnerabilidade das populações assentadas em áreas de alto risco, a proteção e a restauração ambiental de áreas de risco visando evitar a urbanização ilegal, a avaliação geológica de áreas novas antes da ocupação do terreno, e a designação de novas áreas como solos de proteção.

Esta análise demonstra que o plano está orientado para o enfrentamento de ameaças naturais e na procura da redução da vulnerabilidade sócio climática. 


\section{2.}

\section{Análise da contribuição do POT}

No caso da contribuição do POT para a resiliência, a análise considera as categorias descritas pela metodologia apresentada anteriormente, incluindo a categoria adicional de agricultura urbana, com suas bases teóricas e efeitos positivos sobre a mitigação e a capacidade adaptativa da cidade desde que sejam aplicadas as medidas.

As sete categorias abordadas nesta dissertação são: integração e justiça social e físico-territorial, adequação da relação com recursos naturais e o ambiente, aumento da durabilidade e redução da ociosidade (esta é pouco mencionada no POT de Bogotá), abordagem integrada, promoção da diversidade, reconhecimento dos limites e temáticas setoriais para a sustentabilidade (incluída na subcategoria de segurança alimentar).

As subcategorias redução da obsolescência e ociosidade, reconhecimento de limites de densidade e segurança psicológica não foram identificadas explicitamente nos artigos do POT. As demais categorias estão representadas em diferentes partes do plano tanto no componente geral, como nos artigos referentes ao componente urbano.

As subcategorias mais contempladas na revisão prévia foram a "abordagem integrada entre cidade e natureza", com 16\% de abordagem em diferentes itens analisados e "distribuição justa da estrutura urbana", com $10 \%$ de inserção total entre os itens analisados. Outras categorias representativas foram a "Promoção da integração social", com 8\%, "Redução de emissões", "Redução e gestão de resíduos" e "Biodiversidade". Todas distribuídas nas políticas propostas pelo POT e inseridas nas respectivas estratégias.

Sobre a categoria "integração e justiça social e físico-territorial” é importante destacar que tem alta significância dentro do plano, pois é mencionado tanto para a subcategoria "distribuição justa da estrutura urbana" quanto para "promoção da integração social", sem desconhecer que a terceira subcategoria "eliminação da segregação física" também aponta a sua incidência em itens analisados.

Segundo a metodologia e os estudos referenciados nesta dissertação, a ampliação da capacidade adaptativa tem consequências positivas visíveis no aumento da resiliência dos sistemas. No caso da resiliência urbana, comunidades 
mais integradas e facilmente adaptáveis com capital humano fortalecido, serão menos vulneráveis às incertezas da mudança climática. Esta categoria também aborda a importância da conectividade e da integração de pessoas, além do melhoramento da capacidade local através do empoderamento das comunidades, de novas instituições mais autônomas, sustentadas em maior disponibilidade de recursos e conhecimento. A análise pode se encontrar na Tabela 03 - Revisão dos artigos com a categoria Promoção da Integração social

Tabela 03 - Revisão dos artigos com a categoria Promoção da Integração social.

\begin{tabular}{|c|c|c|c|}
\hline \multicolumn{4}{|c|}{ PROMOÇÃO DA INTEGRAÇÃO SOCIAL } \\
\hline Aspectos avaliados & $\begin{array}{l}\text { No. de } \\
\text { ítems }\end{array}$ & $\begin{array}{l}\text { Título em } \\
\text { que } \\
\text { aparece }\end{array}$ & Descrição \\
\hline $\begin{array}{l}\text { Contribuição potencial } \\
\text { para a resiliência urbana }\end{array}$ & & & Capacidade adaptativa \\
\hline $\begin{array}{l}\text { Orientação nos } \\
\text { princípios e diretrizes } \\
\text { gerais da política urbana }\end{array}$ & & & $\begin{array}{l}\text { Título I. CAPÍTULO I. OBJETIVOS PARA O } \\
\text { POT DA CAPITAL } \\
\text { Art. 1 Objetivos: 8. Equilíbrio e Equidade } \\
\text { Territorial para o Benefício Social. h. } \\
\text { Promover a inclusão das variáveis sociais nos } \\
\text { instrumentos de planejamento. (Bogotá, 2013) }\end{array}$ \\
\hline $\begin{array}{c}\text { Itens que se referem à } \\
\text { subcategoria }\end{array}$ & 12 & & \\
\hline $\begin{array}{c}\text { Artigos que se referem à } \\
\text { subcategoria }\end{array}$ & 10 & & \\
\hline \multirow{6}{*}{ Abordagem do tema } & 5 & & $\begin{array}{l}\text { Inclusão de variáveis sociais nos instrumentos } \\
\text { e processos de planejamento. Incluir população } \\
\text { catadora (mais importante Art. } 4 \text { \# 8) }\end{array}$ \\
\hline & 1 & & $\begin{array}{l}\text { Segurança jurídica aos proprietários } \\
\text { recentemente legalizados integrando-os à } \\
\text { cultura tributária. }\end{array}$ \\
\hline & 2 & & $\begin{array}{l}\text { Fortalecimento das instituições e execução } \\
\text { coordenada da inclusão do território rural, } \\
\text { também para a gestão do risco. }\end{array}$ \\
\hline & 1 & & $\begin{array}{l}\text { Desenvolver esquemas de gestão institucional, } \\
\text { social e comunitária, facilitando a governança } \\
\text { ambiental da cidade, com o objetivo de } \\
\text { promover uma cultura ambiental. }\end{array}$ \\
\hline & 1 & & $\begin{array}{l}\text { Apropriação social e uso adequado com o fim } \\
\text { de reduzir os fatores de insegurança e conflitos } \\
\text { no espaço público construído. }\end{array}$ \\
\hline & 2 & & $\begin{array}{l}\text { Incorporar em todos os projetos de } \\
\text { infraestrutura viária e de oferta de transporte } \\
\text { público, as condições necessárias para o acesso } \\
\text { à população em condições de incapacidade e } \\
\text { mobilidade reduzida. }\end{array}$ \\
\hline
\end{tabular}

Fonte: Adaptado de Lemos, 2010, Apêndice 4, p. 273

No Título I, Capítulo I, está claramente definido que um dos objetivos é a 
promoção de equilíbrio e equidade, procurando a coesão social e a diminuição da exclusão sócio espacial. Estes objetivos são facilmente relacionados às subcategorias descritas "promoção da integração social" e "eliminação da segregação social" para as quais o Plano tem mecanismos propostos, como a inclusão de minorias e populações vulneráveis na tomada de decisões locais, assim como a incorporação dos indicadores sociais como parte da gestão institucional, maximizar a governança ambiental e a ação pública, considerando a população com mobilidade reduzida no desenho da cidade e dos espaços públicos.

Todas estas propostas foram definidas para melhorar o acesso da população aos espaços e serviços oferecidos pela cidade, assim como as oportunidades e mecanismos de desenvolvimento social. Na Tabela 04 - Revisão dos artigos com a categoria Eliminação da Segregação física, pode se revistar detalhadamente o descrito no POT.

Tabela 04 - Revisão dos artigos com a categoria Eliminação da Segregação física.

ELIMINAÇÃO DA SEGREGAÇÃO FÍSICA

\begin{tabular}{|c|c|c|c|}
\hline Aspectos avaliados & $\begin{array}{l}\text { \# de } \\
\text { ítems }\end{array}$ & $\begin{array}{l}\text { Título em } \\
\text { que } \\
\text { aparece }\end{array}$ & Descrição \\
\hline $\begin{array}{l}\text { Contribuição potencial } \\
\text { para a resiliência } \\
\text { urbana }\end{array}$ & & & Sensibilidade e capacidade adaptativa \\
\hline $\begin{array}{l}\text { Orientação nos } \\
\text { princípios e diretrizes } \\
\text { gerais da política } \\
\text { urbana }\end{array}$ & & & $\begin{array}{l}\text { Título I. CAPÍTULO I. OBJETIVOS PARA O } \\
\text { POT DO DISTRITO CAPITAL EM } \\
\text { PERSPECTIVA REGIONAL. } \\
\text { Art. } 1 \text { item 8. Equilíbrio e Equidade Territorial } \\
\text { para o Benefício Social. O Distrito promoverá } \\
\text { equilíbrio e equidade na distribuição e oferta de } \\
\text { bens e serviços a todos os cidadãos, Art. 157. São } \\
\text { objetivos desta estratégia: 3. Reverter padrões de } \\
\text { segregação sócio espacial e de género para } \\
\text { diminuir desigualdades sociais, por meio da oferta } \\
\text { de moradia para população de baixa renda, de } \\
\text { qualidade, suficiente e em condições de } \\
\text { localização que promova a mistura social e o } \\
\text { acesso a centros de emprego e serviços urbanos. } \\
\text { (Bogotá, 2013) }\end{array}$ \\
\hline $\begin{array}{l}\text { Itens que se referem à } \\
\text { subcategoria }\end{array}$ & 7 & & \\
\hline $\begin{array}{l}\text { Artigos que se referem } \\
\text { à subcategoria }\end{array}$ & 2 & & \\
\hline Abordagem do tema & 3 & & $\begin{array}{l}\text { Gerar alternativas de moradia sustentável } \\
\text { accessível e econômica para as habitações de baixa } \\
\text { renda em condições urbanísticas adequadas. }\end{array}$ \\
\hline
\end{tabular}




\begin{tabular}{|c|c|l|}
\hline \multirow{2}{*}{1} & $\begin{array}{l}\text { Revitalizar a cidade construída a partir da } \\
\text { qualificação das condições urbanísticas e } \\
\text { ambientais de áreas da cidade com o potencial para } \\
\text { integrar diversos grupos sociais, mistura de usos e } \\
\text { maiores intensidades no uso do solo. }\end{array}$ \\
\cline { 2 - 3 } & 3 & $\begin{array}{l}\text { Incorporar no desenho urbano as necessidades } \\
\text { específicas dos diferentes grupos e sectores } \\
\text { sociais, com enfoque de gênero e diferencial, de tal } \\
\text { forma que permitam o acesso ao espaço urbano em } \\
\text { condições de igualdade e segurança. }\end{array}$ \\
\hline
\end{tabular}

Fonte: Adaptado de Lemos, 2010, Apêndice 4, p. 274

$\mathrm{Na}$ subcategoria da distribuição justa da estrutura urbana, cuja revisão detalhada se referência na tabela 05. Revisão dos artigos com a categoria Distribuição justa de estrutura urbana , foram definidas ações claras, como por exemplo a determinação de maiores investimentos públicos para aquelas áreas com deficiência de equipamentos ou zonas verdes, especialmente as áreas marginalizadas ou com populações vulneráveis.

Tabela 05. Revisão dos artigos com a categoria Distribuição justa de estrutura urbana

\begin{tabular}{|c|c|c|c|}
\hline \multicolumn{4}{|c|}{ DISTRIBUIÇÃO JUSTA DE ESTRUTURA URBANA } \\
\hline Aspectos avaliados & $\begin{array}{l}\text { No. de } \\
\text { ítems }\end{array}$ & $\begin{array}{l}\text { Título em } \\
\text { que } \\
\text { aparece }\end{array}$ & Descrição \\
\hline $\begin{array}{c}\text { Contribuição potencial } \\
\text { para a resiliência urbana }\end{array}$ & & & Sensibilidade \\
\hline $\begin{array}{l}\text { Orientação nos } \\
\text { princípios e diretrizes } \\
\text { gerais da política urbana }\end{array}$ & & & $\begin{array}{l}\text { Titulo I. CAPÍTULO I. OBJETIVOS. Art. } 1 \\
\text { Objetivos: 8. Equilíbrio e Equidade Territorial para } \\
\text { o Benefício Social. d. Investimento público na } \\
\text { atenção das necessidades dos grupos mais } \\
\text { vulneráveis. f. Executar os programas de dotação de } \\
\text { equipamentos e melhoramento integral das áreas } \\
\text { com mais deficiência. } \\
\text { Art 11. Política de dotação de equipamentos. É } \\
\text { objetivo desta política melhorar o nível de vida dos } \\
\text { habitantes da cidade e da região, fortalecer a } \\
\text { estrutura urbana, a rede de cidades da região, } \\
\text { baseado na adequação da oferta de equipamentos em } \\
\text { relação à localização da demanda, dos déficits } \\
\text { existentes, e da melhor distribuição em função da } \\
\text { adequada integração com a região. (Bogota, 2013) }\end{array}$ \\
\hline $\begin{array}{l}\text { Itens que se referem à } \\
\text { subcategoria }\end{array}$ & 15 & & \\
\hline $\begin{array}{l}\text { Artigos que se referem à } \\
\text { subcategoria }\end{array}$ & 9 & & \\
\hline Abordagem do tema & 4 & & $\begin{array}{l}\text { Priorizar o investimento público na atenção das } \\
\text { necessidades das zonas com os grupos mais } \\
\text { vulneráveis e deficitárias, incluindo o espaço } \\
\text { público. }\end{array}$ \\
\hline
\end{tabular}




\begin{tabular}{|c|c|c|}
\hline & 1 & $\begin{array}{l}\text { Promover a gestão de planos parciais em uma escala } \\
\text { que garanta a equidade na distribuição das cargas da } \\
\text { urbanização entre os beneficiados do plano parcial. }\end{array}$ \\
\hline & 4 & $\begin{array}{l}\text { Priorizar os recursos para melhorar, adequar e } \\
\text { construir rodovias e equipamentos de integração nas } \\
\text { áreas onde se façam operações estratégicas de } \\
\text { integração urbana e regional. }\end{array}$ \\
\hline & 2 & $\begin{array}{l}\text { Localizar novos equipamentos de escala urbana e } \\
\text { zonal, com o fim de potenciar o ordenamento e as } \\
\text { funções de centralidade em zonas estratégicas dentro } \\
\text { dos bairros residências. Potencialização de bairros. }\end{array}$ \\
\hline & 1 & Planos de equipamentos para áreas rurais. \\
\hline & 1 & Promoção da diversidade do espaço \\
\hline & 1 & $\begin{array}{l}\text { Condições para a mistura de uso comercial ou de } \\
\text { serviços com o uso residencial. }\end{array}$ \\
\hline & 1 & $\begin{array}{l}\text { Construção da infraestrutura e as redes necessárias } \\
\text { para aumentar a resiliência frente aos riscos por } \\
\text { alagamentos, como estratégia de adaptação frente à } \\
\text { mudança climática. }\end{array}$ \\
\hline
\end{tabular}

Fonte: Adaptado de Lemos, 2010, Apêndice 4, p. 275

Outras estratégias como o melhoramento integral dos bairros, com adequação de equipamentos nos quais sejam detectados déficits dos mesmos, o melhoramento das redes de drenagem pluvial e a mistura como outras tecnologias, como a regeneração para diminuir o risco de inundação e a criação de mecanismos que facilitem a adaptação à mudança climática, entre outras estratégias, fazem do POT um documento que reconhece e identifica as deficiências populacionais atuais (conforme descrito no Capítulo 4), procura a equidade e o reconhecimento das desvantagens da desconexão urbana, da deficiência de equipamentos e infraestrutura na construção de resiliência para todos os habitantes.

No caso do aumento de equipamentos em zonas com déficits, e considerando que esta construção adicional requer recursos que podem aumentar as emissões de gases efeito estufa (GEE), o POT enfatiza a formulação e implementação da política pública de eco urbanismo e construção sustentável baseada em novas construções para reduzir o impacto anteriormente mencionado.

O POT é claro na sua justificativa de elaboração e na adoção da política de eco-urbanismo e construção sustentável, pois busca impulsar as práticas sustentáveis, a gestão institucional, a cultura cidadã e todas medidas encaminhadas na redução da pegada ecológica de Bogotá.

$\mathrm{Na}$ construção sustentável foi inserida a proposta de uso de matérias com coeficientes de refletância altos para melhorar a iluminação das áreas, e desse jeito 
diminuam o consumo de energia causado pelo uso de lâmpadas ou luminárias, gerando menores emissões e colaborando para a redução do consumo energético.

Todos os mecanismos propostos e detectados anteriormente no plano, consideram que é na promoção, integração e na diminuição da segregação que se constroem sociedades mais igualitárias, baseadas em decisões conjuntas e dialogadas, fato que fortalece o tecido social e consegue enfrentar de maneira mais resiliente as ameaças de qualquer tipo, nesta pesquisa, especialmente, o aquecimento global.

Sobre a categoria "adequação da relação com recursos naturais e o ambiente" é importante destacar que todas as medidas que possam ser planejadas neste aspecto tendem a diminuir a pegada ecológica da cidade propriamente dita e a reduzir as emissões dos GEE.

A subcategoria "adequação do consumo de recursos" foi identificada sete vezes em cinco artigos diferentes, que incluem o uso e aproveitamento eficiente do solo como uma incidência na diminuição dos custos necessários para a oferta de infraestrutura. A tabela 06 Revisão dos artigos com a categoria Adequação do consumo de recursos, apresenta a análise dos aspectos avaliados no POT para esta categoria.

Tabela 06 - Revisão dos artigos com a categoria Adequação do consumo de recursos.

\begin{tabular}{|c|c|c|c|}
\hline \multicolumn{4}{|c|}{ ADEQUAÇÃO DO CONSUMO DE RECURSOS } \\
\hline Aspectos avaliados & $\begin{array}{l}\text { No. de } \\
\text { ítems }\end{array}$ & $\begin{array}{l}\text { Título em } \\
\text { que } \\
\text { aparece }\end{array}$ & Descrição \\
\hline $\begin{array}{c}\text { Contribuição potencial } \\
\text { para a resiliência } \\
\text { urbana }\end{array}$ & & & Sensibilidade \\
\hline $\begin{array}{l}\text { Orientação nos } \\
\text { princípios e diretrizes } \\
\text { gerais da política } \\
\text { urbana }\end{array}$ & & & $\begin{array}{l}\text { CAPÍTULO I. OBJETIVOS PARA O POT DO } \\
\text { DISTRITO CAPITAL EM PERSPECTIVA } \\
\text { REGIONAL } \\
\text { Artículo 1. 6. Reconhecimento da interdependência do } \\
\text { sistema urbano e o território rural regional e da } \\
\text { construção da noção de hábitat na região. Neste sentido, } \\
\text { aponta o fortalecimento dos ecossistemas produtores e } \\
\text { reguladores de água, energia e alimentos para o } \\
\text { consumo dos habitantes de Bogotá e a Região, assim } \\
\text { como pelo manejo adequado das descargas e os resíduos } \\
\text { sólidos regionais. (Bogotá, 2013) }\end{array}$ \\
\hline $\begin{array}{l}\text { Itens que se referem à } \\
\text { subcategoria }\end{array}$ & 7 & & \\
\hline $\begin{array}{l}\text { Artigos que se referem } \\
\text { à subcategoria }\end{array}$ & 5 & & \\
\hline
\end{tabular}




\begin{tabular}{|c|c|c|}
\hline \multirow{4}{*}{ Abordagem do tema } & 2 & $\begin{array}{l}\text { Fazer um aproveitamento racional e eficiente do solo } \\
\text { com o fim de aportar na estratégia de ordenamento } \\
\text { territorial e diminuir custos na provisão de infraestrutura } \\
\text { pública. Diminuir o consumo de materiais por meio da } \\
\text { reciclagem. }\end{array}$ \\
\hline & 3 & $\begin{array}{l}\text { Promover o uso eficiente da água, reutilização de águas } \\
\text { servidas dentro da política de eco urbanismo e } \\
\text { construção sustentável. }\end{array}$ \\
\hline & 1 & $\begin{array}{l}\text { Evitar a expansão das infraestruturas de serviços } \\
\text { públicos para zonas afastadas às redes matrizes para } \\
\text { impedir conexões ilegais e deseconomias de escala. }\end{array}$ \\
\hline & 1 & $\begin{array}{l}\text { Fortalecer os ecossistemas produtores e reguladores de } \\
\text { água, energia e alimentos para o consumo dos habitantes } \\
\text { de Bogotá e da Região, assim como pelo manejo } \\
\text { adequado das descargas e os resíduos sólidos regionais. }\end{array}$ \\
\hline
\end{tabular}

Fonte: Adaptado de Lemos, 2010, Apêndice 4, p. 276

O POT também considera a diminuição do consumo dos materiais por meio da reciclagem, a promoção do uso eficiente da água, uma grande preocupação para o governo da cidade, pela forte vulnerabilidade das áreas de recarga hídrica em relação às mudanças de padrões causadas pela mudança climática.

Além disso, o POT inclui a criação da política de construção sustentável, a reutilização das águas servidas; e a redução da expansão da infraestrutura de serviços públicos nas áreas afastadas, onde o controle não seja fácil e possam se apresentar conexões clandestinas, junto com a mudança das tecnologias típicas, por novas soluções de abastecimento diferenciado para essas áreas.

Os incentivos econômicos também são mecanismos descritos no POT, serão aplicados principalmente para as tecnologias de redução de eficiência energética e do uso eficiente de água ou materiais, com a possibilidade de abertura de novas indústrias, a diversificação de mercados e o aumento de emprego nesses novos empreendimentos.

Finalmente, foram incluídas as medidas que visam fortalecer os ecossistemas produtores e reguladores dos ciclos hidrológicos para manter o equilíbrio e conservar a prestação dos seus serviços ambientais.

A subcategoria "redução de demanda e adoção de estratégia de geração de energia limpa local" é apresentada em 3 artigos no Título II, Componente Urbano com o objetivo de promover o uso de energias alternativas, com o financiamento de pesquisas o desenvolvimento e inovação tecnológica, o desenho de incentivos para estimular o uso de energias renováveis e a aplicação de mecanismos de aproveitamento da energia gerada em aterros sanitários. Conforme ao descrito 
anteriormente na Tabela 07 - Revisão dos artigos com a categoria Redução da demanda e estratégias de energia limpa no local, se incluem os aspectos avaliados dentro do POT para esta categoria.

Tabela 07 - Revisão dos artigos com a categoria Redução da demanda e estratégias de energia limpa no local.

\begin{tabular}{|c|c|c|c|}
\hline \\
\hline \multicolumn{4}{|c|}{ REDUÇÃO DA DEMANDA E ESTRATÉGIAS DE ENERGIA LIMPA NO LOCAL } \\
\hline Aspectos avaliados & $\begin{array}{l}\text { No. de } \\
\text { ítems }\end{array}$ & $\begin{array}{l}\text { Título em } \\
\text { que } \\
\text { aparece }\end{array}$ & Descrição \\
\hline $\begin{array}{c}\text { Contribuição potencial } \\
\text { para a resiliência } \\
\text { urbana }\end{array}$ & & & Sensibilidade \\
\hline $\begin{array}{l}\text { Orientação nos } \\
\text { princípios e diretrizes } \\
\text { gerais da política } \\
\text { urbana }\end{array}$ & & & $\begin{array}{l}\text { Artigo 133. Para reduzir o risco pelo desabastecimento } \\
\text { energético, através de medidas de maior poupança e } \\
\text { maior eficiência energéticas deve-se: } \\
\text { b. Desenhar e gerir incentivos que estimulem o uso } \\
\text { racional da energia e fomentem, a utilização de fontes } \\
\text { renováveis, com prioridade de ações no espaço } \\
\text { público, na rede de iluminação publica e as áreas e } \\
\text { edificações públicas. } \\
\text { Art. 134 d. Desenhar e gerir incentivos para estimular } \\
\text { e subsidiar a implementação e utilização de fontes não } \\
\text { convencionais, limpas ou renováveis de energia. } \\
\text { Art. 139. Incentivos à construção } \\
\text { sustentável. Definição de um esquema de incentivos } \\
\text { para os projetos que incluam, aspectos como os } \\
\text { seguintes: 7. O uso racional da energia para a } \\
\text { utilização de fontes renováveis, Tanto em áreas } \\
\text { privadas quanto em áreas públicas. (Bogotá, 2013) }\end{array}$ \\
\hline $\begin{array}{c}\text { Itens que se referem à } \\
\text { subcategoria }\end{array}$ & 6 & & \\
\hline $\begin{array}{l}\text { Artigos que se referem } \\
\text { à subcategoria }\end{array}$ & 3 & & \\
\hline \multirow{3}{*}{ Abordagem do tema } & 2 & & $\begin{array}{l}\text { Promover o uso de energias alternativas, através da } \\
\text { pesquisa, desenvolvimento e inovação tecnológica. }\end{array}$ \\
\hline & 3 & & $\begin{array}{l}\text { Desenhar e gerir incentivos para estimular e subsidiar } \\
\text { a implementação e utilização de fontes não } \\
\text { convencionais, limpas ou renováveis de energia. }\end{array}$ \\
\hline & 1 & & $\begin{array}{l}\text { Aproveitamento energético no equipamento do aterro } \\
\text { sanitário para otimizar produtivamente a combustão } \\
\text { dos gases produzidos. }\end{array}$ \\
\hline
\end{tabular}

Fonte: Adaptado de Lemos, 2010, Apêndice 4, p. 277.

O POT também considera os possíveis desabastecimentos que possam acontecer pela dependência da cidade à energia hidroelétrica, com condições climáticas mais quentes e com clima mais imprevisível, razão pela qual a diversificação da matriz energética é um dos pontos mais importantes nesta área, por ter efeitos positivos no aumento da resiliência. 
Por outro lado a subcategoria "redução da poluição" foi um tema abordado por seis artigos diferentes do POT, como pode se identificar na Tabela 8 - Revisão dos artigos com a categoria Redução de Poluição, com medidas diversas que incluem o melhoramento na qualidade dos corpos hídricos, com objetivo da redução das descargas de esgoto ou de melhorar a qualidade do mesmo, baseada na priorização do saneamento básico; o inventario das áreas contaminadas dentro do perímetro urbano (poluição originada em estações de serviço ou atividades minerais), bem como a recuperação ambiental e morfológica.

Tabela 08 - Revisão dos artigos com Redução de Poluição.

\begin{tabular}{|c|c|c|c|}
\hline \multicolumn{4}{|c|}{ REDUÇÃO DE POLUIÇÃO } \\
\hline Aspectos avaliados & $\begin{array}{l}\text { No. de } \\
\text { ítems }\end{array}$ & $\begin{array}{l}\text { Título em } \\
\text { que } \\
\text { aparece } \\
\end{array}$ & Descrição \\
\hline $\begin{array}{l}\text { Contribuição potencial } \\
\text { para a resiliência } \\
\text { urbana }\end{array}$ & & & Sensibilidade \\
\hline $\begin{array}{l}\text { Orientação nos } \\
\text { princípios e diretrizes } \\
\text { gerais da política } \\
\text { urbana }\end{array}$ & & & $\begin{array}{l}\text { Art. 31. Objetivos da Estrutura Ecológica Principal. São } \\
\text { objetivos da estrutura ecológica principal: Aumentar a } \\
\text { qualidade ambiental e balancear a oferta ambiental no } \\
\text { território em correspondência com povoamento e os } \\
\text { requerimentos, para mitigar a poluição atmosférica, } \\
\text { melhorar a qualidade da paisagem urbano, regular o clima } \\
\text { e reduzir e estes ambiental. }\end{array}$ \\
\hline $\begin{array}{c}\text { Itens que se referem à } \\
\text { subcategoria }\end{array}$ & 7 & & \\
\hline $\begin{array}{l}\text { Artigos que se referem } \\
\text { à subcategoria }\end{array}$ & 6 & & \\
\hline \multirow{4}{*}{ Abordagem do tema } & 4 & & $\begin{array}{l}\text { Ênfases nas soluções que minimizem as descargas de } \\
\text { esgoto aos canais naturais e canais do sistema hídrico da } \\
\text { Estrutura Ecológica Principal. Melhoramento da } \\
\text { qualidade das descargas. Melhoramento da qualidade dos } \\
\text { corpos de agua. Priorizar saneamento básico }\end{array}$ \\
\hline & 1 & & $\begin{array}{l}\text { Estoque georreferenciado, das áreas que contenham os } \\
\text { solos poluídos ou com presunção de poluição dentro do } \\
\text { perímetro urbano da cidade. }\end{array}$ \\
\hline & 1 & & $\begin{array}{l}\text { Os responsáveis das atividades mineras deverão adiantar } \\
\text { atividades de recuperação geomorfológica e ambiental das } \\
\text { áreas afetadas pela atividade extrativa }\end{array}$ \\
\hline & 1 & & $\begin{array}{l}\text { Reduzir utilização de fertilizantes e agroquímicos nos } \\
\text { processos produtivos e promover as atividades de } \\
\text { remineralização e fertilização nos sistemas produtivos } \\
\text { agroecológicos. }\end{array}$ \\
\hline
\end{tabular}

Fonte: Adaptado de Lemos, 2010, Apêndice 4, p. 278

Finalmente, a diminuição de fertilizantes e demais produtos químicos altamente perigosos na produção de alimentos, com substituição das tecnologias 
por outras menos impactantes ao meio ambiente. Esta medida também terá efeitos visíveis na redução de GEE, como os NOx e outros gases com potencial de efeito estufa, razão pela qual terá direta repercussão na mitigação.

No capítulo VI do POT, "Gestão do Risco e a Mudança Climática”, foram definidas as ações que fazem referência à subcategoria "Redução de emissões" encaminhadas para criar estímulos de uso de diferentes fontes combustíveis que causem o mínimo ou nenhuma geração de GEE, tanto para transporte público quanto particular, assim como a promoção e o incentivo para veículos elétricos e híbridos.

Considerando as emissões do transporte como um dos impactos mais evidentes das cidades, a mudança ou escolha de outros mecanismos de transporte terá um grande efeito na sustentabilidade futura e na mobilidade sustentável.

Na tabela 09. Revisão dos artigos com a categoria Redução de emissões é apresentada a análise realizada para cada um dos artigos classificados.

Tabela 09 - Revisão dos artigos com a categoria Redução de emissões.

\begin{tabular}{|c|c|c|c|}
\hline \multicolumn{4}{|c|}{ REDUÇÃO DE EMISSOES } \\
\hline Aspectos avaliados & $\begin{array}{c}\text { \# de } \\
\text { ítems }\end{array}$ & $\begin{array}{l}\text { Título em } \\
\text { que } \\
\text { aparece }\end{array}$ & Descrição \\
\hline $\begin{array}{c}\text { Contribuição potencial } \\
\text { para a resiliência } \\
\text { urbana }\end{array}$ & & & Mitigação \\
\hline $\begin{array}{l}\text { Orientação nos } \\
\text { princípios e diretrizes } \\
\text { gerais da política } \\
\text { urbana }\end{array}$ & & & $\begin{array}{l}\text { CAPÍTULO I. POLÍTICAS DE ORDENAMENTO } \\
\text { TERRITORIAL. Art. 155. Políticas de ordenamento } \\
\text { territorial no solo urbano. 3. Política de hábitat urbano. } \\
\text { Desenvolver medidas urbanas de mitigação da mudança } \\
\text { climática, em responsabilidade com a região, através da } \\
\text { redução de emissões de gases efeito estufa, transformação e } \\
\text { desenvolvimento de tecnologias apropriadas de produção e } \\
\text { comportamentos em modos de transporte, diminuição de } \\
\text { ilhas de calor e aumento de coberturas vegetais nativas e } \\
\text { capacidades de permeabilidade do solo. (Bogotá, 2013) }\end{array}$ \\
\hline $\begin{array}{c}\text { Itens que se referem à } \\
\text { subcategoria }\end{array}$ & 12 & & \\
\hline $\begin{array}{l}\text { Artigos que se referem } \\
\text { à subcategoria }\end{array}$ & 3 & & \\
\hline abordagem do tema & 6 & & $\begin{array}{l}\text { Estimular o uso de médios de transporte público e privado } \\
\text { que não gerem gases efeito estufa GEE. Estimular o uso de } \\
\text { combustíveis e energias alternativas. Promover a utilização } \\
\text { de combustíveis fósseis com pouco porcentagem de } \\
\text { carbono, como gás natural veicular (GNV). Promover a } \\
\text { utilização de combustíveis renováveis e gerar incentivos } \\
\text { para o uso de veículos híbridos e elétricos. }\end{array}$ \\
\hline
\end{tabular}




\begin{tabular}{|c|c|c|}
\hline & 1 & $\begin{array}{l}\text { Reduzir as emissões produto da criação de gado } \\
\text { convencional, através do estabelecimento de sistemas } \\
\text { agroflorestais, silvopastoris e de criação de gado } \\
\text { sustentável, que envolva técnicas de estabilização e semi- } \\
\text { estabilizaçõ, e o cultivo agroecológico de forragens de } \\
\text { clima frio e alta montanha, que não gerem ampliação da } \\
\text { fronteira agropecuária. Implementar mecanismos de } \\
\text { redução de emissões por desmatamento e degradação, } \\
\text { acordados com as comunidades rurais. }\end{array}$ \\
\hline & 1 & $\begin{array}{l}\text { O POT para a Gestão Integral de Resíduos Perigosos e } \\
\text { outros, deve incluir ações para reduzir os Gases Efeito } \\
\text { Estufa - GEE com ênases nos gerados nos processos de } \\
\text { decomposição e incineração }\end{array}$ \\
\hline & 1 & $\begin{array}{l}\text { Estabelecer programas e incentivos para aumentar o } \\
\text { mercado de materiais de construção que no processo de } \\
\text { elaboração tenham gerado a menor quantidade de emissões } \\
\text { GEE. }\end{array}$ \\
\hline & 1 & $\begin{array}{l}\text { A área máxima para estacionamentos permitirá reduzir e } \\
\text { desestimular o deslocamento de veículo particular, além de } \\
\text { incrementar os deslocamentos em transporte público, } \\
\text { garantindo condições de acessibilidade. }\end{array}$ \\
\hline & 2 & $\begin{array}{l}\text { A mistura de usos e a intensificação do aproveitamento do } \\
\text { solo urbano permitirá reduzir os tempos de deslocamento e } \\
\text { impulsar os traslados em modos alternativos de transporte }\end{array}$ \\
\hline
\end{tabular}

Fonte: Adaptado de Lemos, 2010, Apêndice 4

Outra medida adotada pelo POT contempla a troca de tecnologias de produção de gado, já que a criação de gado é outra das grandes fontes de GEE, e uma indústria estabelecida nas áreas rurais ao redor da Bogotá ao envolver mecanismos de produção silvo-pastoril e incluir na concentração de novas tecnologias as comunidades e produtores de tradição, podem beneficiar o alcançar das metas no campo da redução de emissões (na procura da mitigação) e na integração social de comunidades vulneráveis (melhorando a capacidade adaptativa das mesmas).

O POT também considera o envolvimento do Plano de gestão de resíduos sólidos nesta redução através do melhoramento das tecnologias no Aterro Sanitário e a inclusão de tecnologias de captação e uso do biogás.

Outras medidas, como a redução ou limitação do número de vagas de estacionamento, podem diminuir o uso de carro particular e garantir o uso do transporte público e permitirão a redução dos tempos de deslocamento ou o uso de alternativas menos poluentes, como a bicicleta ou o deslocamento de pedestres.

Finalmente convém destacar que a construção, e seus possíveis impactos nas emissões, também são objeto de questionamento ao incentivar o uso de materiais que durante o processo de elaboração tenham utilizado menos recursos naturais e tenham gerado menos emissões. 
A Tabela 10, denominada de Revisão dos artigos com a categoria Redução e gestão de resíduos, apresenta a revisão detalhada das ações de gestão de resíduos que terão efeitos sobre os aspectos da vulnerabilidade.

Tabela 10 - Revisão dos artigos com a categoria Redução e gestão de resíduos.

\section{REDUÇÃO E GESTÃo DE RESÍDUOS}

\begin{tabular}{|c|c|c|c|}
\hline Aspectos avaliados & $\begin{array}{l}\text { \# de } \\
\text { ítems }\end{array}$ & $\begin{array}{l}\text { Título } \\
\text { em que } \\
\text { aparece }\end{array}$ & Descrição \\
\hline $\begin{array}{c}\text { Contribuição potencial } \\
\text { para a resiliência urbana }\end{array}$ & & & Sensibilidade \\
\hline $\begin{array}{l}\text { Orientação nos } \\
\text { princípios e diretrizes } \\
\text { gerais da política urbana }\end{array}$ & & & $\begin{array}{l}\text { TÍTULO II. COMPONENTE URBANO. CAPÍTULO I. } \\
\text { Art. 155. Políticas de ordenamento territorial em solo } \\
\text { urbano.9. Política de serviços públicos. Adotar o sistema } \\
\text { geral para a gestão integral de resíduos, com uma } \\
\text { mudança cultural do consumo e produção responsável } \\
\text { assim como a redução e minimização na fonte de } \\
\text { diferentes tipos de resíduos, suprimindo a disposição final } \\
\text { e o aumento dos processos de aproveitamento e } \\
\text { tratamento. (Bogotá, 2013). }\end{array}$ \\
\hline $\begin{array}{l}\text { Itens que se referem à } \\
\text { subcategoria }\end{array}$ & 12 & & \\
\hline $\begin{array}{c}\text { Artigos que se referem à } \\
\text { subcategoria }\end{array}$ & 2 & & \\
\hline \multirow{6}{*}{ Abordagem do tema } & 1 & & $\begin{array}{l}\text { Avaliar as tecnologias para eliminação de resíduos: } \\
\text { processos de recuperação de energia, biodigestão } \\
\text { mecanizada e pirólise. }\end{array}$ \\
\hline & 3 & & $\begin{array}{l}\text { Fortalecer as políticas e a educação ambiental para } \\
\text { promover as práticas de separação dos resíduos sólidos } \\
\text { gerados na fonte. }\end{array}$ \\
\hline & 3 & & $\begin{array}{l}\text { Fortalecer o setor econômico da reciclagem para melhorar } \\
\text { o aproveitamento de resíduos sólidos reciclável. Incluir } \\
\text { resíduos de demolição e construção. }\end{array}$ \\
\hline & 1 & & $\begin{array}{l}\text { Reduzir ao mínimo os resíduos sólidos do aterro sanitário } \\
\text { da cidade, incorporando tecnologias de tratamento e } \\
\text { aproveitamento nas zonas do aterro. }\end{array}$ \\
\hline & 2 & & $\begin{array}{l}\text { Desenhar e implementar um modelo para o tratamento, } \\
\text { aproveitamento e disposição de lodos e biosólidos dos } \\
\text { resíduos perigosos. }\end{array}$ \\
\hline & 2 & & $\begin{array}{l}\text { Promover o aproveitamento dos resíduos orgânicos por } \\
\text { meio da compostagem para produção de adubo para a } \\
\text { recuperação de solos. }\end{array}$ \\
\hline
\end{tabular}

Fonte: Adaptado de Lemos, 2010, Apêndice 4, p. 279

A subcategoria "Redução e gestão de resíduos" é mencionada em dois artigos diferentes e em 12 ocasiões do plano, e inclui medidas de pesquisa e melhoramento da tecnologia para recuperação de energia gerada pelos resíduos; 
medidas de gestão como o fortalecimento das políticas de educação ambiental com foco na separação e minimização de resíduos gerados, a inclusão dos catadores e a institucionalização de seus trabalhos e aportes, e o aproveitamento dos resíduos orgânicos na compostagem.

Contrariamente, a categoria "aumento da durabilidade e redução da ociosidade" não teve o mesmo impacto na avaliação do POT.

A subcategoria "Redução da obsolescência e ociosidade" foi encontrada apenas em um artigo com quatro itens diferentes, com abordagem da promoção da revitalização dos espaços e a cidade por meio da qualificação ambiental das áreas para facilitar o aproveitamento do potencial do solo e o funcionamento de programas de recuperação de espaços antigamente de grande valor, com recursos das parcerias público-privadas, evitando a deterioração da infraestrutura ainda em bom estado, assegurando dessa maneira o melhoramento da qualidade de vida da população vizinha, pois é necessário acompanhar os processos de adensamento com os processos participativos que envolvem aos habitantes já estabelecidos nessas áreas, de modo a manter o tecido social e fortalecer os relacionamentos já instaurados. Na tabela 11, denominada de Revisão dos artigos com a categoria Redução da obsolescência e ociosidade pode-se encontrar o detalhamento da inclusão desta subcategoria no POT.

Tabela 11 - Revisão dos artigos com a categoria Redução da obsolescência e ociosidade

\begin{tabular}{|c|c|c|l|}
\hline \multicolumn{3}{|c|}{ REDUÇão DA OBSOLESCENCIA E OCIOSIDADE } \\
\hline Aspectos avaliados & $\begin{array}{c}\text { \# de } \\
\text { ítems }\end{array}$ & $\begin{array}{l}\text { Título em } \\
\text { que } \\
\text { aparece }\end{array}$ & \multicolumn{1}{|c|}{ Descrição } \\
\hline $\begin{array}{c}\text { Contribuição potencial } \\
\text { para a resiliência urbana }\end{array}$ & & \multicolumn{1}{|c|}{ Mitigação } \\
\hline $\begin{array}{c}\text { Orientação nos } \\
\text { princípios e diretrizes } \\
\text { gerais da política urbana }\end{array}$ & & $\begin{array}{l}\text { CAPÍTULO I. POLÍTICAS DE ORDENAMENTO } \\
\text { TERRITORIAL NO SOLO URBANO } \\
\text { Art. 155. Políticas de ordenamento territorial no solo } \\
\text { urbano. 6. Política de Revitalização. Propiciar o } \\
\text { adensamento ordenado, especialmente relacionados com } \\
\text { áreas de atividade econômica intensiva, áreas de } \\
\text { integração e elementos da estrutura ecológica principal, } \\
\text { através da geração de condições ambientais, sociais, } \\
\text { ecoômicas e urbanísticas, valorizando o patrimônio } \\
\text { cultural, o maior aproveitamento do solo, a mistura de } \\
\text { usos, a permanência de população residente e proprietária, } \\
\text { a produção de solo reurbanizado e de habitação accessível } \\
\text { para a população de baixa renda (Bogotá, 2013). }\end{array}$ \\
\hline
\end{tabular}




\begin{tabular}{|c|c|c|}
\hline $\begin{array}{c}\text { Itens que se referem à } \\
\text { subcategoria }\end{array}$ & 4 & \\
\hline $\begin{array}{c}\text { Artigos que se referem à } \\
\text { subcategoria }\end{array}$ & 1 & \\
\hline \multirow[t]{2}{*}{ Abordagem do tema } & 3 & $\begin{array}{l}\text { Promover programas de recuperação de setores urbanos } \\
\text { de grande valor patrimonial e a participação conjunta com } \\
\text { a iniciativa privada em outras atuações urbanas de } \\
\text { melhoramento do entorno ou de recuperação dos imóveis, } \\
\text { para reverter os processos de deterioração e gerar um } \\
\text { impacto positivo na qualidade de vida da população } \\
\text { moradora. Incentivar para proteger os bens de interesse } \\
\text { cultural. }\end{array}$ \\
\hline & 1 & Revitalizar a cidade construída. \\
\hline
\end{tabular}

A subcategoria "aumento da durabilidade" não teve nenhuma representação no POT, pois o seu foco foi centrado na revitalização de espaços e no adensamento de áreas previamente intervindas, com o melhoramento da construção baseado na Política de Construção Sustentável, previamente descrita.

De fato, esta categoria e suas possíveis medidas terão um efeito sobre a sensibilidade do sistema ao melhorar as condições das edificações e revitalizar as áreas deterioradas, além de melhorar a capacidade adaptativa em caso de manter os moradores das áreas nos mesmos locais sem perder aquela conexão social e o sentido de comunidade, apesar de serem ofertadas novas construções para novos moradores.

Sobre o tema "Abordagem integrada", a mais representada das subcategorias (sendo também a mais representada dentro do plano) foi "abordagem integrada entre as escalas de cidade e natureza", com 16 artigos do plano e 26 itens referenciando-a, do qual deduz-se que para o plano, o reconhecimento da importância de manter a Estrutura Ecológica Principal (assim descrita pelo mesmo documento) é uma das bases do ordenamento proposto e um dos objetivos principais na procura de uma cidade resiliente e sustentável. Na tabela 12. Revisão dos artigos com a categoria Abordagem integrada entre as escalas da cidade e Natureza se encontra a sínteses da sistematização para esta categoria. Os objetivos que enquadram a ideia de nexo cidade-natureza incluem a detenção dos processos expansivos urbanos (também pode ser incluído como parte da categoria "reconhecimento dos limites"), a definição dos limites do território que permitam à estrutura ecológica manter sua provisão de bens e serviços ambientais e a inclusão dos espaços verdes urbanos (parques e áreas de lazer), como parte da 
estrutura ecológica, devido a sua natureza pública e a possibilidade de funcionar como conectores entre ecossistemas. Reconhecendo que Bogotá é uma cidade marcada pela agua (rios, ravinas, áreas úmidas), o plano procura um ordenamento ao redor da mesma com a recuperação das encostas dos rios e corpos de agua, propondo a exclusão de usos urbanos e promoção de usos agrícolas nas margens do Rio Bogotá, assim como o aumento da cobertura vegetal nessas áreas e o retorno dos corpos de agua privatizados, às mãos do poder público.

Tabela 12. Revisão dos artigos com a categoria Abordagem integrada entre as escalas da cidade e Natureza

\begin{tabular}{|c|c|c|c|}
\hline \multicolumn{4}{|c|}{ ABORDAGEM INTEGRADA ENTRE AS ESCALAS DA CIDADE E NATUREZA } \\
\hline Aspectos avaliados & $\begin{array}{l}\text { \# de } \\
\text { ítems }\end{array}$ & $\begin{array}{l}\text { Título } \\
\text { em que } \\
\text { aparece }\end{array}$ & Descrição \\
\hline $\begin{array}{c}\text { Contribuição potencial } \\
\text { para a resiliência urbana }\end{array}$ & & & Sensibilidade \\
\hline $\begin{array}{l}\text { Orientação nos } \\
\text { princípios e diretrizes } \\
\text { gerais da política urbana }\end{array}$ & & & $\begin{array}{l}\text { Art. 4. Numeral 6. Planejamento ambiental e territorial } \\
\text { para a região. Se procurará definir a estrutura ecológica } \\
\text { principal regional que determina o modelo de ocupação } \\
\text { territorial correspondente, com o fim de assegurar a } \\
\text { oferta de bens e serviços ambientais atendendo as } \\
\text { potencialidades e limitações biofísicas e } \\
\text { socioeconómicas do território. (Bogotá, 2013) }\end{array}$ \\
\hline $\begin{array}{l}\text { Itens que se referem à } \\
\text { subcategoria }\end{array}$ & 26 & & \\
\hline $\begin{array}{l}\text { Artigos que se referem à } \\
\text { subcategoria }\end{array}$ & 16 & & \\
\hline \multirow{6}{*}{ Abordagem do tema } & 6 & & $\begin{array}{l}\text { Recuperação das rondas e zonas de manejo e proteção } \\
\text { dos corpos de agua para a recuperação do Rio Bogotá, } \\
\text { Propondo a exclusão de usos urbanos e a promoção de } \\
\text { usos agrícolas por parte dos municípios sobre a beira } \\
\text { ocidental do Rio. Conectividade da EEP }\end{array}$ \\
\hline & 1 & & $\begin{array}{l}\text { Proteção e restauração ambiental dos morros orientais, } \\
\text { dos morros de Suba e das zonas de risco para evitar a } \\
\text { urbanização ilegal. }\end{array}$ \\
\hline & 5 & & $\begin{array}{l}\text { Delimitar as áreas com valor ambiental e recupera-as no } \\
\text { marco do objetivo ambiental e de controle aos processos } \\
\text { de conurbação. Renaturalização da cidade. }\end{array}$ \\
\hline & 2 & & $\begin{array}{l}\text { Recuperar como espaço público as beiras dos corpos de } \\
\text { agua atualmente privadas. }\end{array}$ \\
\hline & 4 & & $\begin{array}{l}\text { Aumento das coberturas vegetais, e do incremento das } \\
\text { condições de permeabilidade da Capital. }\end{array}$ \\
\hline & 5 & & Drenagem sustentável. \\
\hline
\end{tabular}




\begin{tabular}{|c|c|l|l|}
\hline 2 & $\begin{array}{l}\text { Reduzir a vulnerabilidade dos ecossistemas de alta } \\
\text { montanha e particularmente os páramos e florestas } \\
\text { andinas. }\end{array}$ \\
\hline 1 & $\begin{array}{l}\text { Procurar o aproveitamento dos elementos e valores d } \\
\text { meio biofísico, incluindo sua preservação e restauração } \\
\text { o tratamento ambiental e paisagístico. }\end{array}$ \\
\hline
\end{tabular}

Fonte: Adaptado de Lemos, 2010, Apêndice 4

No reconhecimento da riqueza natural e ecossistêmica que rodeia a cidade, o Plano destaca estratégias para redução da vulnerabilidade dos ecossistemas de paramos e florestas andinas, da mesma forma que planeja a preservação do Cerros Orientais, um ecossistema diverso e extenso que marca o limite oriental da cidade e que atualmente é vulnerável devido à construção e expansão urbana e cujo valor radica na manutenção e proteção do solo contra deslizamentos de terra e uma zona de conexão com os paramos e as áreas de recarga hídrica da cidade. Ações como a ampliação da permeabilidade do solo, através do aumento da cobertura vegetal em toda a cidade e a inclusão de técnicas de drenagem sustentável com a possibilidade de melhorar a retenção de agua em chuvas extremas (próprias da mudança climática e já experimentadas há um par de anos na cidade), são outras das medidas descritas no plano que procuram usar a natureza e suas habilidades (infra-estrutura verde), na construção de capacidade adaptativa e diminuição de sensibilidade, toda vez que também conseguem reduzir a exposição a estes riscos já identificados.

No que se refere a "abordagem integrada entre as escalas da cidade e da região", esta subcategoria foi mencionada em 4 itens diferentes do plano (lembrando que não foi estudado o Título do componente rural, também descrito no POT), e cuja primeira medida tem forte relacionamento com a subcategoria anterior já que na procura da recuperação do Rio Bogotá, estão incluídas ações em toda a região que causa impactos sobre o mesmo, razão pela qual as decisões devem ser concertadas e dialogadas em todos os níveis de organização política. A tabela 13. Revisão dos artigos com a categoria Abordagem integrada entre as escalas da cidade e da região, apresenta a sínteses do revistado no POT ao respeito desta categoria. 
Tabela 13. Revisão dos artigos com a categoria Abordagem integrada entre as escalas da cidade e da região

\begin{tabular}{|c|c|c|c|}
\hline \multicolumn{4}{|c|}{ ABORDAGEM INTEGRADA ENTRE AS ESCALAS DA CIDADE E DA REGIÃO } \\
\hline Aspectos avaliados & $\begin{array}{l}\text { \# de } \\
\text { ítems }\end{array}$ & $\begin{array}{l}\text { Título } \\
\text { em que } \\
\text { aparece }\end{array}$ & Descrição \\
\hline $\begin{array}{c}\text { Contribuição potencial } \\
\text { para a resiliência urbana }\end{array}$ & & & Sensibilidade \\
\hline $\begin{array}{l}\text { Orientação nos } \\
\text { princípios e diretrizes } \\
\text { gerais da política urbana }\end{array}$ & & & $\begin{array}{l}\text { CAPÍTULO I. OBJETIVOS PARA EL POT } \\
\text { Art. 1. numeral 5. Avançar a um modelo de cidade região } \\
\text { diversificado, com um centro especializado em serviços. }\end{array}$ \\
\hline $\begin{array}{l}\text { Itens que se referem à } \\
\text { subcategoria }\end{array}$ & 4 & & \\
\hline $\begin{array}{l}\text { Artigos que se referem à } \\
\text { subcategoria }\end{array}$ & 3 & & \\
\hline \multirow{3}{*}{ Abordagem do tema } & 1 & & $\begin{array}{l}\text { Recuperação das rondas e zonas de manejo e proteção dos } \\
\text { corpos de agua para a recuperação do Rio Bogotá, } \\
\text { Propondo a exclusão de usos urbanos e a promoção de usos } \\
\text { agrícolas por parte dos municípios sobre a beira ocidental } \\
\text { do Rio }\end{array}$ \\
\hline & 2 & & $\begin{array}{l}\text { As decisões que sejam tomadas para o ordenamento } \\
\text { território deveram se orientar na perspectiva regional e } \\
\text { atender sua conveniência e impacto respeito das decisões } \\
\text { que sejam concertadas entre Bogotá D. C. e o departamento } \\
\text { de Cundinamarca }\end{array}$ \\
\hline & 1 & & Integração com a Estrutura Ecológica Regional. \\
\hline
\end{tabular}

Fonte: Adaptado de Lemos, 2010, Apêndice 4, p. 282.

Este aspecto em particular é uma prova da identificação do plano da interdependência do ordenamento da Bogotá com seus vizinhos e como a construção de sustentabilidade e resiliência não pode ser alcançada sem a colaboração e cooperação destes. Ações encaminhadas à proteção da estrutura ecológica principal local, têm que ser ligadas à estrutura ecológica regional e tem que se revistar como as decisões tomadas pelo distrito podem influenciar positiva ou negativamente a realidade da região. Todas estas interações a diferentes níveis, assim como o reconhecimento da profunda conexão entre a mega urbe e seus vizinhos mais pequenos, consegui reforçar as infraestruturas e reduzir a sensibilidade da Bogotá, ao mesmo tempo que proporciona segurança em outros aspectos que facilitam a construção da sustentabilidade.

A última subcategoria "abordagem integrada entre forma, fluxos e atividades" não foi identificada dentro do analise do plano, embora já se tinha mencionada que esta não tem impacto nenhum sobre a resiliência e a adaptação. 
Com relação ao tema "promoção da diversidade" daqual se pode revistar a analise na Tabela 14. Revisão dos artigos com a categoria Biodiversidade e fazendo um relacionamento entre o a integração da natureza no planejamento, a subcategoria "biodiversidade", também muito representativa dentro da análise, novamente apresenta o conceito claro da inclusão e visão da natureza como eixo importante na construção de resiliência dentro da Bogotá. Os objetivos do Plano, claramente determinam a criação de parcerias e alianças entre organismos a diferentes níveis políticos, com o alvo de preservar e manter os recursos e estruturas ecológicas, agora muitos ameaçadas pela expansão urbana na região. A fim de garantir a preservação de esta estrutura ecológica, o Plano procura definir com precisão as áreas vitais, para deste jeito saber orientar os recursos necessários no controle da expansão impactante. Entre as ações encaminhadas segundo o plano, se encontra a renaturalização da cidade, com ênfase na conexão entre os corpos de agua superficial (muito abundantes na Bogotá) e a proteção das zonas húmidas, que também serão ligadas ao Rio Bogotá. A finalidade desta conexão será manter vazões equilibrados nas aguas superficiais e facilitar o fluxo da agua e seu armazenamento natural, evitando assim descargas atípicas durante épocas de chuvas fortes que possam causar inundações ou afeitar outra infraestrutura urbana construída, infraestrutura que pretende também, aproveitar outras maneiras de drenagem (drenagem natural), para melhorar a captura de agua. Da mesma forma, o plano inclui o incremento da cobertura vegetal, nas áreas de corpos de agua e ao longo da cidade, gerando conexões entre os fragmentos de bosque e ecossistemas naturais ainda conservados, tudo isto com repercussões na mitigação ao ser estes locais, sumidouros de $\mathrm{CO}_{2}$, assim como, na preservação de outras espécies moradoras nas áreas e aquelas que no seu processo migratório possam se beneficiar da existência das mesmas.

Tabela 14. Revisão dos artigos com a categoria Biodiversidade

\begin{tabular}{|c|c|c|c|}
\hline \multicolumn{3}{|c|}{ DIVERSIDADE DE VIDA (BIODIVERSIDADE) } \\
\hline Aspectos avaliados & $\begin{array}{c}\text { \# de } \\
\text { ítems }\end{array}$ & $\begin{array}{l}\text { Título } \\
\text { em que } \\
\text { aparece }\end{array}$ & Descrição \\
\hline $\begin{array}{c}\text { Contribuição potencial } \\
\text { para a resiliência urbana }\end{array}$ & & & Sensibilidade e mitigação \\
\hline
\end{tabular}




\begin{tabular}{|c|c|c|}
\hline $\begin{array}{l}\text { Orientação nos } \\
\text { princípios e diretrizes } \\
\text { gerais da política urbana }\end{array}$ & & $\begin{array}{l}\text { Art. 4. Numeral 2. Conservação, restauração e } \\
\text { aproveitamento sustentável dos recursos naturais } \\
\text { regionais e do meio ambiente. Estas ações promoverá } \\
\mathrm{e} \\
\text { garantirão a conservação, recuperação, restauração, } \\
\text { uso e aproveitamento sustentável dos bens e serviços } \\
\text { ambientais da região, como suporte do bem-estar } \\
\text { social e desenvolvimento económico, através da } \\
\text { execução de projetos coordenados, concertados e co- } \\
\text { financiados. (Bogotá, 2013) }\end{array}$ \\
\hline $\begin{array}{l}\text { Itens que se referem à } \\
\text { subcategoria }\end{array}$ & 12 & \\
\hline $\begin{array}{l}\text { Artigos que se referem à } \\
\text { subcategoria }\end{array}$ & 9 & \\
\hline \multirow{6}{*}{ Abordagem do tema } & 4 & $\begin{array}{l}\text { Delimitar as áreas com valor ambiental e recuperá-las. } \\
\text { Aportar os recursos para o investimento nos } \\
\text { ecossistemas estratégicos no solo urbano. }\end{array}$ \\
\hline & 3 & $\begin{array}{l}\text { As ações sobre a Estrutura Ecológica Principal terão } \\
\text { como eixo central a renaturalização da cidade. }\end{array}$ \\
\hline & 1 & $\begin{array}{l}\text { Ligar as áreas húmidas com o sistema de rios e } \\
\text { quebradas para garantir o equilíbrio das vazões da } \\
\text { cidade, sempre garantindo a qualidade da agua }\end{array}$ \\
\hline & 1 & $\begin{array}{l}\text { Levar uma vazão ecológica de agua limpa a cada uma } \\
\text { das zonas húmidas da capital, desde as quebradas } \\
\text { localizadas nos diferentes morros, e drenagem pluvial } \\
\text { com boa qualidade hídrica, com o fim de potenciar a } \\
\text { biodiversidade presente. }\end{array}$ \\
\hline & 1 & Drenagem sustentáveis \\
\hline & 2 & Incrementar as coberturas vegetáis \\
\hline
\end{tabular}

Fonte: Adaptado de Lemos, 2010, Apêndice 4, p. 283

Importa sublinhar que os ecossistemas de alta montanha chamados "paramos e subparamos" (ecossistemas circundantes da Bogotá), têm uma grande importância na captura de GEE e também de agua, razão pela qual a manutenção e bom estado destes pode garantir o abastecimento de agua na cidade e fazê-la mais forte num futuro de secas prolongadas. É claro que na medida que as atividades descritas possam ser implementadas na cidade, a mesma vai reduzir sua sensibilidade e mitigar os efeitos das emissões feitas. Os itens relacionados a essa subcategoria incluem atividades precisas que são mostra da intenção da gestão descrita pela política de ordenamento. De ser adotadas, podem fazer a diferença enorme na construção de resiliência na Bogotá.

Quanto à subcategoria "diversidade econômica" foi considerada 4 vezes no plano. Os artigos revistados e a análise da categoria se apresenta na Tabela 15 . Revisão dos artigos com a categoria Diversidade econômica. A diversidade econômica inclui diversidade de investimentos, parcerias público-privadas com o alvo de renovar o centro da cidade; a potenciação da produtividade das áreas 
rurais, melhorando os assentamentos rurais com o fim de manter condições ótimas de funcionamento de serviços e comercialização de produtos.

Tabela 15. Revisão dos artigos com Diversidade econômica.

DIVERSIDADE ECONÔMICA

\begin{tabular}{|c|c|c|c|}
\hline Aspectos avaliados & $\begin{array}{l}\# \text { de } \\
\text { ítems }\end{array}$ & \begin{tabular}{|l|} 
Título \\
em que \\
aparece
\end{tabular} & Descrição \\
\hline $\begin{array}{l}\text { Contribuição potencial } \\
\text { para a resiliência urbana }\end{array}$ & & & Sensibilidade \\
\hline $\begin{array}{l}\text { Orientação nos princípios } \\
\text { e diretrizes gerais da } \\
\text { política urbana }\end{array}$ & & & - \\
\hline $\begin{array}{l}\text { Itens que se referem à } \\
\text { subcategoria }\end{array}$ & 4 & & \\
\hline $\begin{array}{l}\text { Artigos que se referem à } \\
\text { subcategoria }\end{array}$ & 3 & & \\
\hline \multirow{4}{*}{ Abordagem do tema } & 1 & & $\begin{array}{l}\text { Os projetos de renovação urbana, com investimento } \\
\text { público, serão orientados para atrair investimento privado } \\
\text { e consolidar e centro da cidade de Bogotá como centro da } \\
\text { rede regional de cidades e para consolidar as centralidades } \\
\text { através de operações estratégicas }\end{array}$ \\
\hline & 1 & & $\begin{array}{l}\text { Promover e potenciar a produtividade das áreas rurais, } \\
\text { através da diversificação e integração econômica com a } \\
\text { cidade região Bogotá -Cundinamarca, e fortalecer o } \\
\text { sistema de assentamentos humanos rurais. }\end{array}$ \\
\hline & 1 & & $\begin{array}{l}\text { Adiantar atuações urbanísticas e estratégias sócio } \\
\text { económicas que estimulem e aumentem as dinâmicas } \\
\text { próprias dos setores de comercio e serviços, mediante a } \\
\text { priorização das intervenções em áreas de atividade } \\
\text { económica intensiva e as áreas de integração, com o alvo } \\
\text { de promover o aumento da produtividade e o } \\
\text { fortalecimento das cadeias de abastecimento e } \\
\text { comercialização com outros setores estratégicos para a } \\
\text { cidade e a região. }\end{array}$ \\
\hline & 1 & & $\begin{array}{l}\text { Potenciar a atividade turística e as zonas de interesse para } \\
\text { esta atividade. }\end{array}$ \\
\hline
\end{tabular}

Fonte: Adaptado de Lemos, 2010, Apêndice 4, p. 284

A diversidade econômica procura também estimular o intercâmbio cidaderegião, assim como fornecer mecanismos que aumentem a produtividade, melhorem o abastecimento, promovam o turismo e outras atividades similares na região. Este relacionamento próximo, diminui a pegada ecológica da Bogotá e aporta equilíbrio na circulação dos recursos na mesma região, evitando a perda de recursos principalmente monetários para outras áreas. Por outro lado, a subcategoria "diversidade social" aparece no plano duas vezes, com a promoção da inclusão de variáveis sociais no planejamento que facilitem a apropriação e participação da população nas eleições comunais, e a formalização de 
oportunidades para pessoas com deficiência, nos projetos públicos e de serviços estaduales, lembrando o efeito na ampliação da capacidade adaptativa da cidade, na aplicação desta subcategoria. Na Tabela 16. Revisão dos artigos com a categoria Diversidade social são descritos os artigos revistados e a abordagem do tema no POT.

Tabela 16. Revisão dos artigos com Diversidade social.

\begin{tabular}{|c|c|c|c|}
\hline \multicolumn{4}{|c|}{ DIVERSIDADE SOCIAL } \\
\hline Aspectos avaliados & $\begin{array}{l}\text { \# de } \\
\text { ítems }\end{array}$ & $\begin{array}{l}\text { Título } \\
\text { em que } \\
\text { aparece }\end{array}$ & Descrição \\
\hline $\begin{array}{l}\text { Contribuição potencial } \\
\text { para a resiliência urbana }\end{array}$ & & & Capacidade adaptativa \\
\hline $\begin{array}{l}\text { Orientação nos } \\
\text { princípios e diretrizes } \\
\text { gerais da política urbana }\end{array}$ & & & - \\
\hline $\begin{array}{l}\text { Itens que se referem à } \\
\text { subcategoria }\end{array}$ & 2 & & \\
\hline $\begin{array}{l}\text { Artigos que se referem à } \\
\text { subcategoria }\end{array}$ & 1 & & \\
\hline \multirow{2}{*}{ abordagem do tema } & 1 & & $\begin{array}{l}\text { Promover a inclusão das variáveis sociais nos } \\
\text { instrumentos e processos de planejamento de modo que } \\
\text { se favoreça a identidade, apropriação, pertença, } \\
\text { participação e solidariedade da população num território } \\
\text { comum. }\end{array}$ \\
\hline & 1 & & $\begin{array}{l}\text { Organização de programas para a formalização de } \\
\text { atividades e para a ampliação de oportunidades para } \\
\text { pessoas com limitações físicas e população vulnerável, } \\
\text { com o alvo de inclui-os em projetos oficiais de obra } \\
\text { pública e de serviços estaduales. }\end{array}$ \\
\hline
\end{tabular}

Fonte: Adaptado de Lemos, 2010, Apêndice 4, p. 285

O tema "Reconhecimento dos limites" teve uma grande representação na subcategoria "reconhecimento de limites do território" que claramente se refere a limitar a expansão urbana através de limites administrativos, políticos e territoriais, com o objetivo de proteger áreas naturais com aporte de serviços ambientais importantes, impossíveis de ser prestados pela mesma cidade no caso da perda destes ecossistemas. As abordagens descritas no plano para limites de território foram o uso do solo disponível de maneira eficiente; o ajuste da oferta de moradia de interesse social à disponibilidade desse solo; a estrutura ecológica como o principal elemento ordenador; a restrição para novos projetos de urbanização em áreas de ameaça alta de inundação, para evitar o aumento de população em risco, assim como nas áreas que tenham sido usadas para 
disposição de resíduos de construção ou demolição devido ao caráter instável das zonas. Na Tabela 17. Revisão dos artigos com a categoria Reconhecimento de limites do território e do desenvolvimento econômico, se pode encontrar a análise das estratégias desta categoria revistada no POT. Todas estas estratégias podem influir positivamente na mitigação das emissões de GEE, associada à preservação de espaços naturais na cidade, que por sua vez, reduz a sensibilidade do sistema urbano.

Tabela 17. Revisão dos artigos com Reconhecimento de limites do território e do desenvolvimento econômico.

\begin{tabular}{l}
\multicolumn{2}{|c|}{ RECONHECIMENTO DE LIMITES DO TERRITÓRIO E DO DESENVOLVIMENTO } \\
ECONOMICO
\end{tabular}




\begin{tabular}{|l|l|l|l|}
\hline \multicolumn{3}{|c|}{ RECONHECIMENTO DE LIMITES DO TERRITÓRIO E DO DESENVOLVIMENTO } \\
ECONOMICO
\end{tabular}

Finalmente se encontra dentro da avaliação a categoria "Temáticas setoriais para a sustentabilidade", na qual foi mencionada em 24 ocasiões nas diferentes subcategorias propostas. Também es importante sublinhar que foi nesta categoria onde foi incluída uma nova subcategoria "agricultura urbana" de acordo com o descrito previamente no capitulo de metodologia. Durante a avaliação do plano não foi encontrado nenhum item ou artigo que tivesse relação com a subcategoria "Segurança psicológica", razão pela qual este item não é descrito e avaliado nesta análise.

Para o caso da "Acessibilidade e mobilidade sustentável", cujo principal impacto é sobre a mitigação, pela redução das emissões devido à mudança de combustíveis ou meios de transporte não poluentes (bicicleta), e a redução da sensibilidade, devido ao impacto da deficiência estrutural na vulnerabilidade socioambiental, o plano pretende garantir a conectividade da cidade com transporte público e infraestrutura, facilitando a conexão cidade-região e articulando-a de modo eficiente. Enquanto planeja sobre esta articulação, o plano também cria múltiplas centralidades ou áreas que possam ser dotadas de 
infraestrutura e equipamentos com o alvo de reduzir os deslocamentos gerados pela deficiência de parques, hospitais, escolas ou universidades, mesmo creches, que segundo o plano também podem contribuir na igualdade de oportunidades para as mulheres no acesso ao trabalho perto do cuidado dos filhos, todos mecanismos que sem dúvida vão diminuir a sensibilidade da população, principalmente a mais vulnerável. Somado à dotação de equipamentos outra medida descrita é a geração de moradias acessíveis em preços e espaços que permitam o acesso e inclusão da população mais vulnerável à cidade. Do mesmo jeito o plano destaca a promoção de modos de transporte público e não motorizado entendendo os impactos negativos do carro particular na configuração das cidades como custos altos na infraestrutura, maior consumo de energia, isolamento e desconexão social, perdida de biodiversidade e solo para culturas, entre outras. Na Tabela 18. Revisão dos artigos com a categoria Acessibilidade e mobilidade sustentável são analisadas as estratégias que procuram proteger a saúde dos habitantes da cidade, ao fomentar ambientes com espaços caminháveis, e ao mesmo tempo motivar e promover a prosperidade econômica. Se bem em geral os objetivos são claros, as ações não estão delimitadas e podem ficar num "limbo" que impeça a possibilidade de realização das mesmas.

Tabela 18. Revisão dos artigos com a categoria Acessibilidade e mobilidade sustentável

\begin{tabular}{|c|c|c|c|}
\hline \multicolumn{4}{|c|}{ ACESSIBILIDADE E MOBILIDADE SUSTENTÁVEL } \\
\hline Aspectos avaliados & $\begin{array}{l}\text { No. de } \\
\text { ítems }\end{array}$ & \begin{tabular}{|l} 
Título em \\
que \\
aparece \\
\end{tabular} & Descrição \\
\hline $\begin{array}{c}\text { Contribuição } \\
\text { potencial para a } \\
\text { resiliência urbana }\end{array}$ & & & Mitigação e sensibilidade \\
\hline $\begin{array}{l}\text { Orientação nos } \\
\text { princípios e } \\
\text { diretrizes gerais da } \\
\text { política urbana }\end{array}$ & & & $\begin{array}{l}\text { CAPÍTULO I. OBJETIVOS PARA O POT } \\
\text { Artículo 1. Numeral 6. Reconhecimento da } \\
\text { interdependência do sistema urbano e o território rural } \\
\text { regional e da construção da noção de hábitat na região.... } \\
\text { Com este objetivo se promoverão o desenvolvimento de } \\
\text { atuações que integrem o entorno natural com a moradia, } \\
\text { os equipamentos, a acessibilidade aos serviços públicos e } \\
\text { a mobilidade. (Bogotá, 2013) }\end{array}$ \\
\hline $\begin{array}{l}\text { Itens que se referem } \\
\text { à subcategoria }\end{array}$ & 6 & & \\
\hline $\begin{array}{l}\text { Artigos que se } \\
\text { referem à } \\
\text { subcategoria }\end{array}$ & 3 & & \\
\hline
\end{tabular}




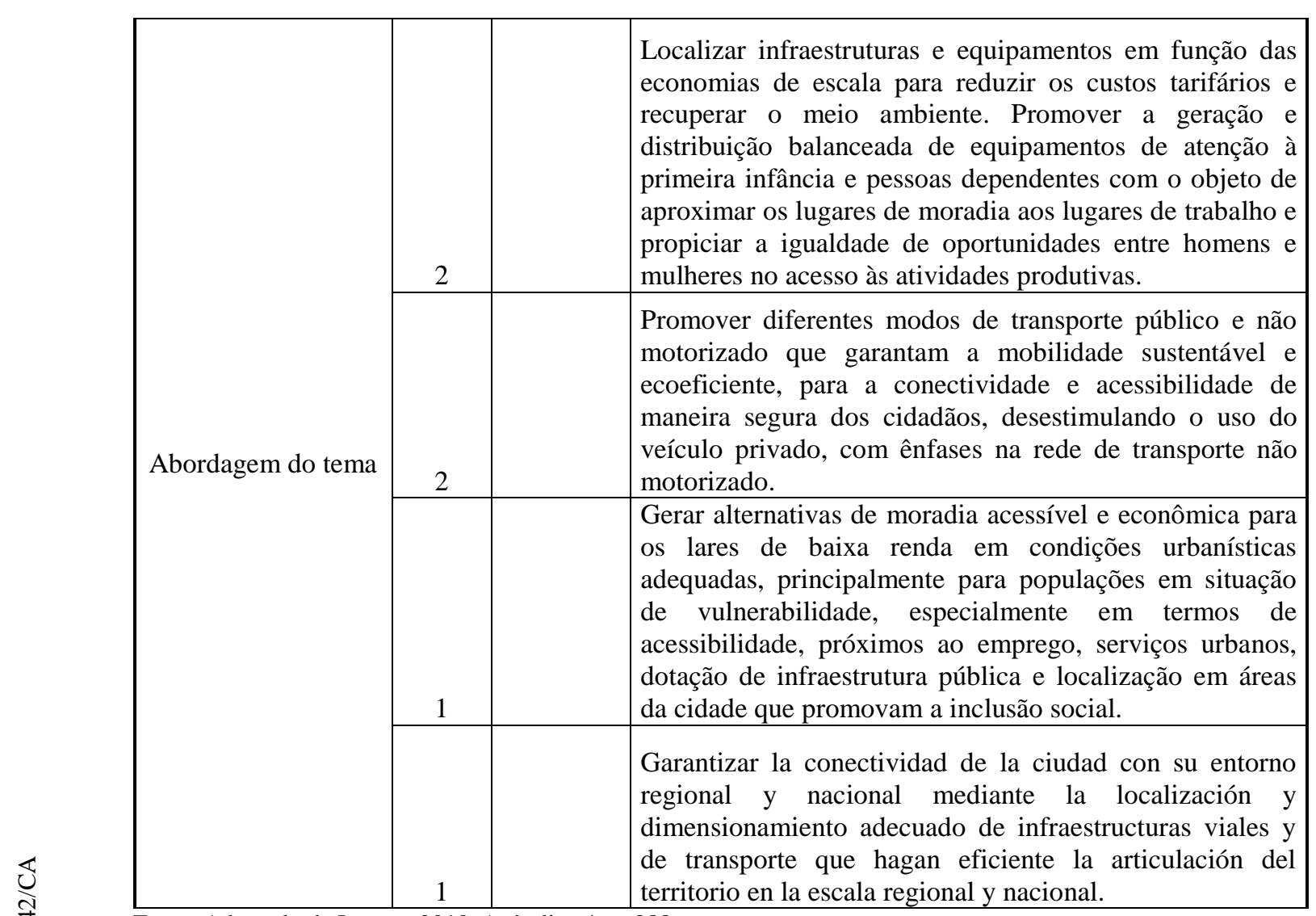

Fonte: Adaptado de Lemos, 2010, Apêndice 4, p. 288

A subcategoria de temáticas setoriais para a sustentabilidade com mais aparições dentro dos artigos analisados foi "Acesso à Habitação", suas principais contribuições estão na redução da sensibilidade e na ampliação da capacidade adaptativa, razão pela qual o melhoramento e facilidade de acesso à habitação de qualidade é essencial para a construção da resiliência.

Segundo o Diagnóstico do POT, Bogotá tem uma deficiência habitacional (seja por quantidade ou qualidade da mesma) em todos os estratos socioeconômicos, a Figura 9. Déficit de moradias na Bogotá, segundo estrato econômico, apresenta os dados:

\begin{tabular}{|c|c|c|c|c|c|c|}
\hline \multirow{2}{*}{ Estrato Social } & \multicolumn{2}{|c|}{ Moradias deficientes } & \multicolumn{2}{c|}{ Deficiência quantitativa } & \multicolumn{2}{c|}{ Deficiência qualitativa } \\
\cline { 2 - 7 } & Moradias & $\%$ & Moradias & $\%$ & Moradias & $\%$ \\
\hline 1 & 47.946 & 27,8 & 27.044 & 15,7 & 20.902 & 12,1 \\
\hline 2 & 140.747 & 16,9 & 63.381 & 7,6 & 77.366 & 9,3 \\
\hline 3 & 58.933 & 7,4 & 22.805 & 2,9 & 36.128 & 4,5 \\
\hline 4 & 3.909 & 1,7 & 581 & 0,2 & 3.328 & 1,4 \\
\hline 5 & 1.176 & 1,7 & 0 & 0 & 1.176 & 1,7 \\
\hline 6 & 605 & 1,1 & 0 & 0 & 605 & 1,1 \\
\hline Não informa-Não responde & 4.730 & 16,2 & 2.718 & 9,3 & 2.012 & 6,9 \\
\hline Totais & $\mathbf{2 5 8 . 0 4 6}$ & $\mathbf{1 1 , 8}$ & $\mathbf{1 1 6 . 5 2 9}$ & $\mathbf{5 , 3}$ & $\mathbf{1 4 1 . 5 1 7}$ & $\mathbf{6 , 5}$ \\
\hline
\end{tabular}

Fonte: Adaptado Documento de suporte POT, 2013, p. 348

Figura 9. Déficit de moradias na Bogotá, segundo estrato econômico 
Tomando em conta esta realidade, onde os extratos baixos (1 e 2) representam quase o $45 \%$ da deficiência total de moradias, o plano define as moradias de interesse social e prioritário como o objetivo principal de fornecimento por parte do setor público, gerando solo para estas construções, na procura de diminuir o mercado informal e os assentamentos ilegais e não regulados que normalmente são fonte de vulnerabilidade populacional devido à baixa qualidade da moradia estabelecida. Esta promoção da legalização incluirá o oferecimento de alternativas econômicas viáveis que compitam com o mercado ilegal.

Outra estratégia concebida pelo POT é a priorização do reassentamento de pessoas morando em condições de alto risco pela localização de casas em áreas de possíveis deslizamentos de terra, inundações ou riscos geológicos. Ao mesmo tempo o plano também condiciona os novos processos de urbanização naquelas áreas que tenham sido classificadas como áreas de alta ameaça por deslizamentos, tomando em conta o princípio de precaução e a possibilidade latente do acontecimento dos mesmos em situações de variabilidade climática. Em concordância com a geração de habitação para as populações vulneráveis e de baixa renda, o plano procura fornecer equipamentos e serviços públicos de qualidade, desenvolvendo projetos que gerem empregos para os habitantes e fortaleçam as populações não só ao nível habitacional, mas também no nível econômico e social. A análise pode-se encontrar na Tabela 19. Revisão dos artigos com a categoria Acesso à habitação, com as descrições por artigo do POT, das estratégias propostas para melhorar a condição de déficit habitacional.

Tabela 19. Revisão dos artigos com Acesso à habitação

\begin{tabular}{|c|c|l|l|}
\hline \multicolumn{3}{|c|}{ ACESSO À HABITAÇÃo } \\
\hline Aspectos avaliados & $\begin{array}{c}\text { \# de } \\
\text { ítems }\end{array}$ & $\begin{array}{l}\text { Título em } \\
\text { que } \\
\text { aparece }\end{array}$ & Descrição \\
\hline $\begin{array}{c}\text { Contribuição } \\
\text { potencial para a } \\
\text { resiliência urbana }\end{array}$ & & & Sensibilidade e capacidade adaptativa \\
\hline
\end{tabular}




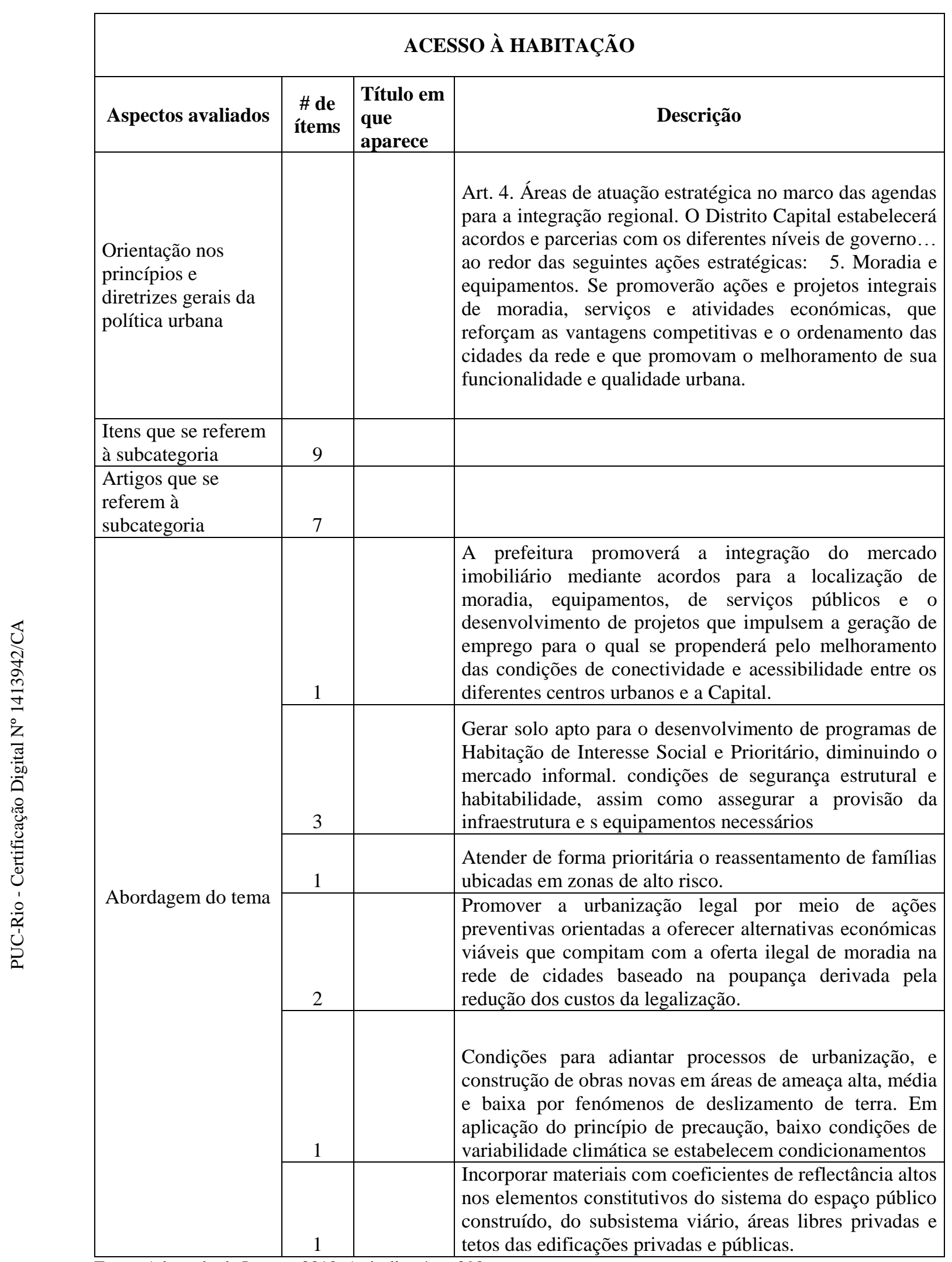

Fonte: Adaptado de Lemos, 2010, Apêndice 4, p. 290

Dentro dos objetivos do plano está estabelecido o propósito da gestão urbana de melhorar as condições na qualidade de vida para todos os habitantes da cidade, procurando equidade e um ambiente seguro e sano que permita o 
desenvolvimento humano em todos seus níveis; razão pela qual é importante a seguinte subcategoria "Saúde pessoal e do ambiente", apresentada na Tabela 20. Revisão dos artigos com a categoria saúde pessoal e do ambiente que, porem só foi descrita nos artigos avaliados duas vezes. Com ações, como a identificação das áreas da cidade com presença de poluição com vista ao isolamento e prevenção de assentamentos não regulados que possam se tornar fontes de afetação da saúde dos moradores ou o estabelecimento de objetivos quantitativos na procura do aumento do espaço público, o POT define sua direção para fazer do ambiente construído, um espaço estimulante e diverso que reduza a sensibilidade dos habitantes ao melhorar suas condições de vida.

Tabela 20. Revisão dos artigos com a categoria saúde pessoal e do ambiente

\section{SAÚDE PESSOAL E DO AMBIENTE}

\begin{tabular}{|c|c|c|c|}
\hline Aspectos avaliados & $\begin{array}{c}\text { \# de } \\
\text { ítems }\end{array}$ & $\begin{array}{l}\text { Título em } \\
\text { que } \\
\text { aparece } \\
\end{array}$ & Descrição \\
\hline $\begin{array}{l}\text { Contribuição } \\
\text { potencial para a } \\
\text { resiliência urbana }\end{array}$ & & & Sensibilidade \\
\hline $\begin{array}{l}\text { Orientação nos } \\
\text { princípios e } \\
\text { diretrizes gerais da } \\
\text { política urbana }\end{array}$ & & & $\begin{array}{l}\text { Art. 7. Políticas Ambientais. 1.Qualidade ambiental para } \\
\text { o desenvolvimento humano integral. É propósito central } \\
\text { da gestão urbana melhorar equitativamente a qualidade de } \\
\text { vida das gerações presentes e futuras, criando um } \\
\text { ambiente seguro, saudável, estimulante, diverso e } \\
\text { participativo para o desenvolvimento integral do ser } \\
\text { humano, a nível individual e coletivo, no físico, o social e } \\
\text { o económico. }\end{array}$ \\
\hline $\begin{array}{l}\text { Itens que se referem } \\
\text { à subcategoria }\end{array}$ & 2 & & \\
\hline $\begin{array}{l}\text { Artigos que se } \\
\text { referem à } \\
\text { subcategoria }\end{array}$ & 2 & & \\
\hline \multirow{2}{*}{ Abordagem do tema } & 1 & & $\begin{array}{l}\text { Identificar por parte da Secretaria Distrital de Ambiente, } \\
\text { as zonas que apresentam condições de poluição, que } \\
\text { signifiquem riscos para a saúde humana, ao superar os } \\
\text { limites permissíveis da normatividade vigente. }\end{array}$ \\
\hline & 1 & & $\begin{array}{l}\text { O indicador mínimo de espaço público efetivo de obter na } \\
\text { vigência do presente plano será de } 6 \mathrm{~m}^{2} \text { por habitante, em } \\
\text { consonância com os objetivos de cidade compacta da } \\
\text { estratégia de ordenamento territorial. }\end{array}$ \\
\hline
\end{tabular}

Fonte: Adaptado de Lemos, 2010, Apêndice 4, p. 291

A quarta subcategoria "Segurança física", revistada detalhadamente na Tabela 21. Revisão dos artigos com a categoria segurança física, foi identificada em quatro ocasiões no POT cada uma com uma ação clara em algum dos 
componentes da vulnerabilidade: a exposição procura ser reduzida para os habitantes em condições de alta vulnerabilidade na relocação dos mesmos em áreas de menor risco; a sensibilidade por sua vez pode ser reduzida com a limitação das zonas de risco que evite a legalização e construção de novas moradias em estas zonas, ambas situações identificadas no diagnóstico inicial do POT e apresentadas no capitulo 4 desta pesquisa.. Do mesmo modo se enfoca na identificação da vulnerabilidade de algumas populações da capital ao desabastecimento da agua com propostas próprias para estas situações especificas. A revisão particular pode ser observada na tabela Tabela 21. Revisão dos artigos com a categoria segurança física.

Tabela 21. Revisão dos artigos com a segurança física.

\section{SEGURANÇA FÍSICA}

\begin{tabular}{|c|c|c|c|}
\hline Aspectos avaliados & $\begin{array}{l}\text { No. de } \\
\text { ítems }\end{array}$ & $\begin{array}{l}\text { Título em } \\
\text { que aparece }\end{array}$ & Descrição \\
\hline $\begin{array}{l}\text { Contribuição } \\
\text { potencial para a } \\
\text { resiliência urbana }\end{array}$ & & & Sensibilidade, exposição e capacidade adaptativa \\
\hline \multicolumn{4}{|l|}{$\begin{array}{l}\text { Orientação nos } \\
\text { princípios e } \\
\text { diretrizes gerais da } \\
\text { política urbana }\end{array}$} \\
\hline $\begin{array}{l}\text { Itens que se referem } \\
\text { à subcategoria }\end{array}$ & 4 & & \\
\hline $\begin{array}{l}\text { Artigos que se } \\
\text { referem à } \\
\text { subcategoria }\end{array}$ & 2 & & \\
\hline \multirow{3}{*}{ Abordagem do tema } & 1 & & $\begin{array}{l}\text { Identificar as zonas da capital e da Região Central } \\
\text { vulneráveis ao desabastecimento de agua e alimentos } \\
\text { frente aos cenários de variabilidade e mudança } \\
\text { climática que possam afeitar a Bogotá no contexto } \\
\text { regional. }\end{array}$ \\
\hline & 2 & & $\begin{array}{l}\text { Fazer os análise técnicos para a identificação e } \\
\text { delimitação das zonas de risco, no marco dos } \\
\text { processos de legalização e reassentamento. }\end{array}$ \\
\hline & 1 & & $\begin{array}{l}\text { Reduzir a exposição principalmente daquelas pessoas } \\
\text { em condições de alta vulnerabilidade. }\end{array}$ \\
\hline
\end{tabular}

Fonte: Adaptado de Lemos, 2010, Apêndice 4, p. 292

A subcategoria da "Segurança psicológica" não foi identificada textualmente no POT, mas como esta tem a ver com a coesão social e a conformação de um tecido coletivo é de esperar que as ações mencionadas anteriormente sobre a inclusão 
social, a diminuição da segregação e a diversidade social contribuam com seu impacto positivo na construção de capacidade adaptativa daquelas comunidades, principalmente as mais vulneráveis.

A última categoria revistada na Tabela 22. Revisão dos artigos com a categoria Combate à pobreza, embora tenha incidência sobre os três componentes da vulnerabilidade (exposição, capacidade adaptativa e sensibilidade), só foi tomada em conta numa ocasião dentro do Plano na procura da construção de equilíbrio e equidade com a diminuição dos fatores que geram pobreza especialmente os associados à degradação ambiental no Marco das políticas de planificação regional para a construção da Região-Cidade.

Tabela 22. Revisão dos artigos com a categoria Combate à pobreza

\section{COMBATE À POBREZA}

\begin{tabular}{|c|c|c|c|}
\hline Aspectos avaliados & $\begin{array}{c}\text { \# de } \\
\text { ítems }\end{array}$ & $\begin{array}{l}\text { Título em } \\
\text { que } \\
\text { aparece } \\
\end{array}$ & Descrição \\
\hline $\begin{array}{l}\text { Contribuição potencial } \\
\text { para a resiliência } \\
\text { urbana }\end{array}$ & & & Sensibilidade, exposição e capacidade adaptativa \\
\hline $\begin{array}{l}\text { Orientação nos } \\
\text { princípios e diretrizes } \\
\text { gerais da política } \\
\text { urbana }\end{array}$ & & & $\begin{array}{l}\text { Art. 2. Marco General para las acciones del Distrito } \\
\text { Capital en la construcción de la Región Capital Bogotá } \\
\text { - Cundinamarca. }\end{array}$ \\
\hline $\begin{array}{l}\text { Itens que se referem à } \\
\text { subcategoria }\end{array}$ & 1 & & \\
\hline $\begin{array}{l}\text { Artigos que se referem } \\
\text { à subcategoria }\end{array}$ & 1 & & \\
\hline Abordagem do tema & 1 & & $\begin{array}{l}\text { Diminuir os fatores que geram pobreza } \text { e } \\
\text { vulnerabilidade urbana ou rural, especialmente os } \\
\text { relacionados com a acumulação dos impactos e a } \\
\text { degradação ambiental. }\end{array}$ \\
\hline
\end{tabular}

Fonte: Adaptado de Lemos, 2010, Apêndice 4, p. 294.

Finalmente e como parte do complemento à metodologia estudada se fiz a avaliação da subcategoria adicional dentro da categoria de "Temáticas setoriais para a sustentabilidade", esta foi "Segurança alimentar" descrita no marco teórico e o capitulo de Metodologia a segurança alimentar associada à Agricultura urbana, peri-urbana e na produção local, atua na redução da sensibilidade, ao oferecer os alimentos para a população em distâncias mais curtas, reduzindo assim a dependência de produtos importados sujeitos a flutuações nos preços, instabilidade política e mudança climática, nas regiões produtoras. Estas situações mencionadas anteriormente podem afetar a segurança alimentar das cidades, o que 
exemplifica como o fortalecimento da agricultura urbana e peri-urbana, amplia a capacidade adaptativa ao manter os alimentos perto de onde são requeridos, especialmente em casos de afetação climática, onde a infraestrutura pode sair de funcionamento e as necessidades podem ser fornecidas rapidamente. Para o caso da análise do POT da Bogotá foram avaliados dois artigos com este aspecto, juntos enfocados no incentivo à Agricultura urbana e a criação de hortas, com o objetivo de diminuir temperaturas ou o efeito de ilha de calor na cidade e aportar produtos para a segurança alimentar, assim como o fortalecimento dos camponeses da região. A tabela 23. Revisão dos artigos com a categoria Segurança alimentar-Agricultura urbana apresenta os aspectos avaliados e a descrição feita para esta sub-categoria.

Tabela 23. Revisão dos artigos sobre Segurança alimentar

\section{SEGURANÇA ALIMENTAR- AGRICULTURA URBANA*}

\begin{tabular}{|c|c|c|c|}
\hline Aspectos avaliados & $\begin{array}{l}\text { \# de } \\
\text { ítems }\end{array}$ & $\begin{array}{l}\text { Título em } \\
\text { que } \\
\text { aparece }\end{array}$ & Descrição \\
\hline $\begin{array}{l}\text { Contribuição potencial } \\
\text { para a resiliência } \\
\text { urbana }\end{array}$ & & & Capacidade adaptativa \\
\hline $\begin{array}{l}\text { Orientação nos } \\
\text { princípios e diretrizes } \\
\text { gerais da política } \\
\text { urbana }\end{array}$ & & & - \\
\hline $\begin{array}{l}\text { Itens que se referem à } \\
\text { subcategoria }\end{array}$ & 2 & & \\
\hline $\begin{array}{l}\text { Artigos que se referem } \\
\text { à subcategoria }\end{array}$ & 2 & & \\
\hline Abordagem do tema & 2 & & $\begin{array}{l}\text { Promoção e diversificação de hortas urbanas que } \\
\text { contribuam à diminuíam da temperatura e aportem à } \\
\text { segurança alimentar. }\end{array}$ \\
\hline
\end{tabular}

Fonte: Adaptado de Lemos, 2010, Apêndice 4

*Categoria não incluída na metodologia inicial 


\section{3}

\section{Analise de resultados finais}

Como se tinha descrito no capítulo de metodologia as proporções dos componentes de vulnerabilidade na matriz de padrões de relação entre categorias de sustentabilidade e resiliência são: $12 \%$ para contribuição no componente Exposição; $79 \%$ em componente sensibilidade; $29 \%$ em componente capacidade adaptativa e finalmente $25 \%$ em resultados na procura da mitigação. Para a avaliação do POT de Bogotá as proporções de resultados esperados foram muitos parecidas, a maior, a sensibilidade com um $80 \%$ dos itens classificados e avaliados. A exposição mostrou um aumento com 19\% dos itens totais, devido à incidência da subcategoria (abordagem integrado entre cidade e natureza). A mitigação por sua parte manteve sua proporção de $25 \%$ e o componente que mostrou redução na avaliação e classificação do plano foi a capacidade adaptativa, só $22 \%$ dos itens classificados.

Uma análise total que inclua a orientação e contribuição do POT é o resultado final de este projeto. Como foi mencionado anteriormente o POT da Bogotá surgiu depois de fenômenos extremos que aconteceram na Colômbia, no ano 2010-2011, e que mostraram a enorme vulnerabilidade da cidade e seus arredores, principalmente a chuvas fortes, como consequências como alagamentos ou remoção de terra. A perda de ecossistemas que cumpriam funções de proteção do solo e captura de agua, causaram ainda maiores problemas e afetação de populações vulneráveis e perto das margens do Rio Bogotá. Nesse cenário foi reconhecida a importância da mudança do Plano e a inclusão de novas variáveis, como a análise de risco de áreas, dentro das bases de execução de planejamento, para o desenvolvimento de um novo POT que olhara não só os típicos pressupostos de planejamento, mas os novos desafios e a realidade populacional da Bogotá. Esta nova olhada foi sem dúvida insumo de um novo plano com uma tendência muito mais focada na procura da resiliência territorial, sempre com a redução dos riscos por alagamentos como um objetivo claro. O Diagnóstico do POT inclui estes estudos e o objetivo da restrição de urbanização nas áreas identificadas com alto vulnerabilidade aos alagamentos ou processos de remoção de terra. Aplicando a matriz de análise de orientação se mostra que o POT tem informação especifica sobre risco e vulnerabilidade sócio climática da cidade e 
está incluída neste. Sua orientação também é descrita de maneira clara e explícita no Título I Capitulo VI. Gestão do Risco e a Mudança Climáticas, onde são definidos os objetivos e principalmente as determinantes para a gestão, incluindo a aplicação do princípio de precaução e as normas necessárias para a redução da vulnerabilidade física. Finalmente no objetivo 8, dos objetivos gerais do POT se descreve como prioridade "Atender o reassentamento de famílias situadas em zonas de alto risco". Estas razoes fazem do plano da Bogotá uma política orientada para o enfrentamento de ameaças naturais, visando na redução de vulnerabilidades sociais e climáticas, com ampliação da resiliência urbana.

Sobre a contribuição do plano de ordenamento a maior contribuição esperada é na redução da sensibilidade, devido ao alto número de medidas na procura de uma distribuição justa de estrutura urbana e a tendência na construção de uma abordagem integrada entre cidade e natureza, que também reduz a exposição da cidade a variações extremas do clima. É claro que a inclusão de áreas verdes ao interior da cidade e a proteção de ecossistemas urbanos que aportam serviços ambientais reduzem a pegada ecológica da cidade (no caso da redução das GEE), aumentam a captura de agua com um solo mais permeável, melhoram a saúde dos habitantes e o clima urbano, preservam e aumentam a biodiversidade regional, e aportam também outro tipo de contribuições positivas como atrativo turístico pelos espaços naturais, sentimento de pertença e orgulho pela cidade. Por sua vez esta subcategoria também tem uma marcada incidência na componente exposição, pois impõe limites à expansão urbana, principalmente em áreas com alta vulnerabilidade de alagamentos ou remoção de terra, assim como limites nas áreas que fazem parte da Estrutura Ecológica Principal (já descrita em capítulos anteriores) e que é o principal eixo de ordenamento da Bogotá, segundo o POT. É importante destacar neste ponto, que a EEP, não só faz parte da Bogotá, mas é um complexo grupo de diversos ecossistemas todos contidos dentro da bacia do Rio Bogotá, o qual pode representar um desafio na gestão e planejamento, já que inevitavelmente exigirá a adoção de medidas regionais e uma maior conexão institucional entre autoridades locais e departamentais, o que pode diminuir os alcances positivos destas medidas de não apresentar se uma boa comunicação e participação de todos os atores com interesses.

Por outro lado, ou aumento da cobertura vegetal e a proteção de ecossistemas naturais também afeta de maneira positiva a mitigação, na captura de GEE, a 
mitigação por sua parte é desejável devido a ser esta uma das principais medidas a serem tomadas na adaptação à mudança climática.

O POT define com claridade a redução das emissões na Sub-Seção 2 Lineamentos de Mitigação frente à Mudança Climática, assim como na exigência do estabelecimento da Política de Ecourbanismo e Construção sustentável (adotada por o Decreto 566 de 2014), com o alvo de aumentar as normas e padrões na construção, para que seja mais sustentável e garanta a redução da perda de recursos do meio ambiente. Por sua vez, a definição desta política permite inferir que a emissão de GEE vão estar controlada por estes padrões o qual pode ser considerado como positivo no alcance de resultados em outros aspectos como o adensamento, ou na construção de habitação de qualidade para população de baixa renda ou nas medidas de reassentamentos que tenham a ser feitos, pela condição de alto risco de certas famílias.

Sem a definição de fatores potencializadores, só com a análise dos resultados nos componentes de vulnerabilidade e na mitigação, o POT, certamente orientado na construção de resiliência, apresenta uma contribuição frágil na construção da mesma para Bogotá, tomando em conta a avaliação dos desafios atuais do planejamento a posição de POT frente à limitação do desenvolvimento (insustentável) urbano é positiva ao definir a estrutura ecológica como o eixo principal de ordenamento e a procura da redução das pressões sobre a mesma como um objetivo primordial do planejamento, ao mesmo tempo que define o controle do processo de expansão urbana na periferia da Bogotá. O seguinte desafio, à distribuição dos riscos sócio-climáticos e enfrentamento da pobreza, está relacionado com a categoria Integração e justiça social e físico-territorial, a qual foi a de maior quantidade de artigos incidentes dentro do Plano, o que faz pensar no compromisso do planejamento na redução da vulnerabilidade mediante o aumento da capacidade adaptativa das populações, principalmente aquelas com maior grau desta.

À interdependência entre as escalas de gestão e atuação e a acuidade da escala local de atuação e representação (participação) é um desafio já mencionado na análise inicial, porque não é claro dentro do Plano como vai ser tomada em conta essa participação de atores em todos os níveis, não só institucional, mas também comercial, econômico, mesmo os habitantes da região, não têm uma definição clara de seu papel, na tomada de decisões em aspectos que envolvam a Bogotá e 
suas áreas circundantes. As ações participativas se bem são muito mencionadas, não estão definidas dentro da lei o que pode diminuir o impacto inicialmente positivo dos processos participativos nele planteados.

Para o caso do desafio de enfrentamento e atuação sobre um objeto impreciso relacionado à mudança do clima, exigindo do planejamento, a redefinição de prioridades e incorporação de novos instrumentos, o POT já traz inserida a mudança climática na sua concepção, além da inclusão da gestão do risco no seu centro de planejamento, razão pela qual a contribuição deste na estruturação de novos mecanismos de atuação ante incertezas climáticas já foi discutida e aceitada como possível fonte de mecanismos positivos para a cidade. Finalmente para o desafio decorrente relativo à medição (quantificação) do problema (climático) e controle de resultados da atuação sobre ele, o POT inclui indicadores de medição constante para o seguimento da avaliação de riscos, para o caso da mobilidade inclui análise de comportamento das redes viárias; também indicadores da qualidade ambiental e funcional do espaço público construído; indicadores específicos para as políticas das temáticas setoriais. 


\section{7 \\ Considerações finais}

$\mathrm{Na}$ atualidade em nossa sociedade é esperado que sejam definidas políticas de planejamento urbano com o propósito de mediar entre o crescimento urbano e a proteção do solo, cada vez mais escasso e vital, procurando um balance entre crescimento e prosperidade e preservação.

Frente as incertezas trazidas pela mudança climática e no meio do crescente aumento populacional das cidades, o planejamento urbano deve se mostrar inovador, procurando outras alternativas de planejamento e olhando as cidades como espaços onde acontecem relacionamentos de indivíduos com sistemas ecológicos ao longo do tempo.

O POT da Bogotá representa, de acordo com o avaliado nesta dissertação, um primeiro passo nessa procura de novas premissas do planejamento, numa cidade altamente vulnerável á mudança cliamtica. Na avaliação do aspecto da orientação, a análise mostra que o plano está orientado para o enfrentamento de ameaças naturais e na procura da redução da vulnerabilidade sócio climática. Sua base de construção está influenciada por acontecimentos do passado recente, como os eventos extremos de 2010-2011, razões entre outras, que motivaram a mudança da política. Além disso, os objetivos nele previstos, contém de maneira explícita a construção de uma cidade com mecanismos e medidas de adaptação e mitigação aos efeitos da mudança climática, estes incluídos no capitulo de Gestão de riscos e mudança climática, todo isto como base para construção de resiliência na cidade.

De outro lado no aparte de avaliação da contribuição potencial à resiliência do POT, é importante destacar que o documento faz referência particular na redução das emissões (principais responsáveis da mudança nos padrões de composição atmosférica) e planeja diversas formas de lidar com o assunto, medidas que, como foi descrito na pesquisa, têm alta repercussão na mitigação. Outro ponto a destacar, além da definição de mecanismos de redução das emissões, é a forte relação entre novas construções como projetos impactantes de forma negativa nesse mesmo aspecto, razão pela qual, o Plano define novas políticas como a Política de Urbanismo e Construção sustentável que deve ser aplicada para os 
novos empreendimentos a ser desenvolvidos, estabelecendo bases sólidas e medidas claras para novos projetos. A contribuição também em positiva em aspectos como a Abordagem integrada e a Integração social, a primeira sugerindo a importância da recuperação da ronda do Rio Bogotá e sua bacia, como eixo organizador do território (o qual também está relacionado ao estabelecimento de limites físicos ao desenvolvimento), medida que expõe uma presencia clara dos ecossistemas e zonas verdes como elementos de ordenação e não de detenção do progresso. Assim como é reconhecido o papel de ordenamento do rio, o POT também reconhece a importância dos Cerros Orientais, na preservação da agua e a conexão com ecossistemas mais importantes e vulneráveis (paramos) decisivos na manutenção do ciclo hídrico. Todas as medidas sem dúvida terão efeitos positivos ao consolidar os sistemas ecológicos de suporte e prestação de serviços ambientais, reduzindo de esta maneira a sensibilidade da cidade para fortalecer a resiliência urbana.

As medidas com relação à Integração social terão maiores contribuições na área de distribuição justa da infraestrutura (uma das categorias com maior prioridade no POT), o qual faz pensar que na concepção desta política de planejamento se entende a forte conexão entre equidade social e equidade territorial, oferecendo equipamentos e investimento público nas áreas menos atendidas, com diversidade de espaços, mistura de solos e priorização do gasto público nas populações mais vulneráveis e deficitárias. Das medidas de integração ainda não fica claro a metodologia que será empregada na segurança da participação dos grupos de interesse, o qual pode representar certa fragilidade dentro do Plano. Neste ponto é importante destacar que o processo de avaliação procurava olhar a lei desde o ponto de vista da vulnerabilidade e os possíveis resultados sobre ela das ações planteadas e não tinha interesse em definir ou analisar mecanismos de gestão, mesma razão que fez ao pesquisador excluir a revisão dos fatores "potencializadores", componente da metodologia não usado nesta pesquisa.

Das dúvidas do POT ao analisar e avaliar sua contribuição, a principal delas é a definição e participação dos diversos poderes locais que fazem parte da Área Metropolitana da Bogotá e para as quais o POT não contém mecanismos claros de atuação. Neste aspecto fica a dúvida das ferramentas, com as quais conta o Plano, para assegurar a participação de todos os municípios envolvidos, procurando responder às necessidades particulares e criando ações de planejamento em 
conjunto. Isto é valido na urbanização mais visível da Sabana de Bogotá, uma área no passado referente de solo rural e produção agrícola da Bogotá, que hoje tem se convertido numa das maiores áreas de expansão com a construção de condomínios fechados e casas campestres, que embora tem melhorado o ingresso dos municípios, estão gerando impactos negativos próprios dos conhecidos "subúrbios" ao aumentar as distancias das viagens e o uso do carro para o deslocamento (com o consequente aumento das emissões de GEE).

Este exemplo expõe que a lei local não é suficiente se não se conta com uma lei regional e uma definição clara das atuações da centralidade (Bogotá) e seus redores (municípios vizinhos), pois as motivações devem ir além do desenvolvimento econômico e devem ser concertadas entre os diversos atores interessados.

Nesse Reconhecimento dos limites para o desenvolvimento econômico se descobre o outro "calcanhar de Aquiles" na definição e construção do POT, pois fica claro com a exposição acima descrita, que este vazio jurídico esta sendo atualmente aproveitado pelo mercado imobiliário no aumento dos ingressos do mesmo, mediante a ocupação de municípios com instituições públicas fracas e focadas na obtenção de lucro rápido e crescimento sem planejamento do espaço privado e assim como da mudança na vocação do solo uma vez considerado apropriado para a agricultura.

No final, é esperado que o novo plano que está sendo desenvolvido atualmente pela nova administração municipal da Bogotá (projeto que começou em Janeiro de 2017), tome em conta os resultados nesta pesquisa expostos e saiba incluir as medidas positivas analisadas ao longo da dissertação, do POT anterior, ao mesmo tempo que reconheça os erros e limitações também descritos, e desta maneira melhore o comprometimento do Plano, com o enfrentamento dos desafios da mudança climática, assim como a redução das vulnerabilidades sócio-climáticas na presença de eventos naturais ameaçadores para as cidades e seus habitantes, dando relevância aos instrumentos de planejamento na construção de adaptação. 


\section{8 \\ Referências bibliográficas}

AHERN, J., LEDUC, E., \& YORK, M. L. Biodiversity planning and design: sustainable practices. Washington: Island Press, 2006.

AHERN, J. (2011). From fail-safe to safe-to-fail: Sustainability and resilience in the new urban world. Landscape and Urban Planning, 100(4), 341-343.).

ALCALDIA MAYOR DE BOGOTA-SECRETARIA DE PLANEACIONDANE. Encuesta de Calidad de Vida BOGOTÁ 2007. Bogotá D.C., Colombia, 2007. Disponível em: < https://www.dane.gov.co/files/investigaciones/condiciones_vida/ecvb/ECV B_07.pdf >. Acesso em: Dezembro 2016.

ANGEL, S., J. PARENT, D. L. CIVCO and A.M. BLEI. Making Room for a Planet of Cities, Lincoln Institute, Cambridge, 2011.

ATTOLICO, A. Building Resilience through Territorial Planning: The Experience of Province of Potenza. Procedia Economics and Finance, 2014, vol. 18, p. 528-535.)

BERG, P. The Bioregional Approach for Making Sustainable Cities. Disponivel em http://www.planetdrum.org/bioreg_approach_cities.htm acesso dezembro 2016

BIRKMANN, J., GARSCHAGEN, M., KRAAS, F., QUANG, N., 2010. Adaptive urban governance: new challenges for the second generation of urban adaptation strategies to climate change. Sustain. Sci. 5 (2), 185206. http://dx.doi.org/10.1007/s11625-010-0111-3.

BIRKMANN, J., GARSCHAGEN, M., \& SETIADI, N. (2014). New challenges for adaptive urban governance in highly dynamic environments: Revisiting planning systems and tools for adaptive and strategic planning. Urban Climate, 7, 115-133.

BLACK, R., ADGER, N., ARNELL, N., DERCON, S., GEDDES, A., \& THOMAS, D. (2011). FORESIGHT: Migration and Global Environmental Change Final Project Report (Government Office for Science, 2011); available at http://go.nature.com/somswg Acceso em: junho 2016 p.154

BLANCO, H., ALBERTI, M., FORSYTH, A., KRIZEK, K. J., RODRIGUEZ, D. A., TALEN, E., \& ELLIS, C. (2009). Hot, congested, crowded and diverse: Emerging research agendas in planning. Progress in Planning, 71(4), 153-205. 
BOGOTA (Municipio). Soportes técnicos de los motivos que justifican la modificación. Disponível em < http://www.sdp.gov.co/portal/page/portal/PortalSDP/POT_2020/soporteste cnicos/Soportes-TecnicosPOT.pdf>. Acesso em: set. 2015.

BOGOTA (Municipio). Documento técnico de soporte. Disponível em $<$

http://www.sdp.gov.co/portal/page/portal/PortalSDP/POT_2020/soporteste cnicos/DTS_Decreto_364_de_2013.pdf>. Acesso em: Maio. 2016

BOGOTA (Municipio). Memoria justificativa/ documento resumen. Disponível em < http://www.sdp.gov.co/portal/page/portal/PortalSDP/POT_2020/soporteste cnicos/MEMORIA_JUSTIFICATIVA_DECRETO_364_DE_2013.pdf>. Acesso em: set.2015.

CAMAGNI, R.; GIBELLI, M.C.; RIGAMONTI, P. Urban mobility and urban form: the social and environmental costs of different patterns of urban expansion. Ecological economics, 2002, vol. 40, no 2, p. 199-216

CASTILLO DE HERRERA, M. Grupo de Investigación Procesos urbanos en hábitat, vivienda $e$ informalidad. Procesos urbanos informales y territorio. Ensayos entorno a la construcción de sociedad, territorio y ciudad. Universidad Nacional de Colombia, Bogotá, D.C., diciembre 2009

CHILDERS, D. L., PICKETT, S. T., GROVE, J. M., OGDEN, L., \& WHITMER, A. (2014). Advancing urban sustainability theory and action: Challenges and opportunities. Landscape and Urban Planning, 125, 320-328.

CITY MAYORS. City Mayors: largest cities in the world by population density (1 to 125). City Mayor Statistics. Disponivel em http://www.citymayors.com/statistics/largest-cities-density-125.html. Aceso Dezembro 2016

COLOMBIA. Decreto 364 de 26 de Agosto de 2013. Pelo qual se modificam excepcionalmente as normas urbanísticas do Plano de Ordenamento Territorial de Bogotá D. C. Bogotá DC, 26 ago 2013.

Lei 1454 de 28 de Junho de 2011. Pela qual se ditam normas orgânicas sobre Ordenamento Territorial e são modificadas outras disposições. Bogotá, DC, 28 jun 2011.

. Lei n. 388, de 18 de julho de 1997. Pela qual se modifica a Lei 9 de 1989, e a Lei 2 de 1991 e se ditam outras disposições, Bogotá, DC, 18 jul 1997.

DALY, H. Beyond Growth: The Economics of Sustainable Development. Boston: Beacon Press, 1997. 
DUBBELING, M, CAMPBELL, M. HOESKSTRA, F. VAN Veenhuizen, R. Construyendo Ciudades Resilientes. Revista Agricultura Urbana No. 22 dic. 2009 Disponivel em http://www.actaf.co.cu/revistas/revista_au_118/AU22/1b_editorial_rau22.pdf Aceso em: novembro 2016.

FRIEND, R., et al. Mainstreaming urban climate resilience into policy and planning; reflections from Asia. Urban Climate, 2014, vol. 7, p. 6-19.

FOLKE, C., CARPENTER, S., ELMQVIST, T., GUNDERSON, L., HOLLING, C. S., \& WALKER, B. (2002). Resilience and sustainable development: building adaptive capacity in a world of transformations. AMBIO: A journal of the human environment,31(5), 437-440

FUCHS, R., CONRAN, M., LOUIS, E. Climate change and Asia's coastal urban cities: can they meet the challenge? Environ, Urban. Asia 2 (1), 13-28. $2011 . \quad$ Disponivel em https://www.apngcr.org/resources/files/original/fe17876f6868055c20f3a6e2f71d0229.pdf Acceso em: dezembro 2016

GAITAN, M., CANCINO, J., BEHRENTZ, E. Análisis del estado de la calidad del aire en Bogotá. Revista de Ingeniería Universidad de los Andes, (26), 81-92. 2007. Disponivel em http://www.scielo.org.co/pdf/ring/n26/n26a11.pdf. Acesso em: dezembro 2016

GRIMM, N. B, et al. 'Global change and the ecology of cities', Science, 2008, 319.

HOLLING, C. S. (1973). Resilience and stability of ecological systems. Annual review of ecology and systematics, 1-23.

HOPKINS, R. 2000. The food producing neighbourhood. In Sustainable Communities: The Potential for Eco-Neighbourhoods, ed. H. Barton, 199-215. London: Earthscan.

IDEAM, PNUD, Alcaldía de Bogotá, Gobernación de Cundinamarca, CAR, Corpoguavio, Instituto Alexander von Humboldt, Parques Nacionales Naturales de Colombia, MADS, DNP. Vulnerabilidad de la región capital a los efectos del cambio climático. Plan Regional Integral de Cambio Climático para Bogotá Cundinamarca (PRICC). Bogotá, 2014. 7 p.

INSTITUTO DE ESTUDIOS URBANOS (IEU). Universidad Nacional. $2017 . \quad$ Disponivel em https://institutodeestudiosurbanos.info/endatos/0100/0140/01412.htm. Acesso em Março 2017

INTERGOVERNMENTAL PANEL ON CLIMATE CHANGE (IPCC). Climate change 2007: impacts, adaptation and vulnerability. Contribution of Working Group II to the Fourth Assessment Report of the Intergovernmental Panel on Climate Change. Cambridge: Cambridge University Press, 2007b. 878p. 976p. 
INTERGOVERNMENTAL PANEL ON CLIMATE CHANGE IPCC. Climate Change 2014: Synthesis Report. Contribution of Working Groups I, II and III to the Fifth Assessment Report of the Intergovernmental Panel on Climate Change [Core Writing Team, R.K. Pachauri and L.A. Meyer (eds)]. Geneva, Switzerland. p. 5, 16.

JABAREEN, Y. Planning the resilient city: Concepts and strategies for coping with climate change and environmental risk. Cities, 2013, vol. 31, p. 220-229.

KATES, R.W., Cautionary tales: adaptation and the global poor. Climatic Change, 2000. 45(1), 5-17.

KLEIN, R. JT; SCHIPPER, E. L. F.; DESSAI, S. Integrating mitigation and adaptation into climate and development policy: three research questions. Environmental science \& policy, 2005, vol. 8, no 6, p. 579588).

LEMOS RODRIGUES CAMPOS, M. Adaptação de cidades para mudança climática: Uma metodologia de análise para os planos diretores municipais. Rio de Janeiro, 2012. 295p. Tese de doutorado Programa de Pós-Graduação em Urbanismo (PROURB), Faculdade de Arquitetura e Urbanismo (FAU), Universidade Federal do Rio de Janeiro (UFRJ).

LITMAN, T. Analysis of public policies that unintentionally encourage and subsidize urban sprawl. 2015.

MARTIN, L., JUSTO, J. B. Análisis, prevención y resolución de conflictos por el agua en América Latina y el Caribe. 2015.

MASSIRIS CABEZA, Á. (2000). "Ordenamiento Territorial y procesos de construcción regional". Revista Credencial Historia. Bogotá: Biblioteca Luis Ángel Arango, del Banco de la República. Disponible en: http://www.lablaa.org/blaavirtual/geografia/masir/presen.htm

MORENO FLORES, O. Agricultura Urbana: Nuevas Estrategias de Integración Social y Recuperación Ambiental en la Ciudad. Centro de Estudios Arquitectónicos, Urbanísticos y del Paisaje. Universidad Central de Chile Santiago, Chile. Agosto 2007

NAREDO, J.M. Ciudades y crisis de civilización. Revista Documentación Social, 2000, no 119.

NAVEH, Z (2001) Ten major premises for a holistic conception of multifunctional landscapes. Landscape Urban Plan 57:269-284

NEWMAN, P.; JENNINGS, I. Cities as sustainable ecosystems. Principles and practices. Washington, D.C: Island Press, 2012.

NYU-STERN. The NYU Urban Expansion Program. 2015, p.2. 
ODI/ECDPM/GDI/DIE (2012) 'Confronting scarcity: Managing water, energy and land for inclusive and sustainable growth', European Union Report on Development: 208. Brussels, p.1.

ORGANIZACIÓN MUNDIAL METEOROLOGICA. EI Niño/Oscilación del Sur. Disponível em https://library.wmo.int/pmb_ged/wmo_1145_es.pdf Acesso em Abril 2017.

ONU-HABITAT, 2009. Urbanización para el desarrollo urbanoPolíticas para un mundo de ciudades 2009. Fundación cultural Javeriana de artes gráficas, Bogota, p.36.

ONU-HABITAT, 2014. Construcción de ciudades más equitativas. Políticas públicas para la inclusión en América Látina, Bogotá.

PACHECO, M. P. S. Expansão e tendências do mercado imobiliário de Porto Alegre (2005 - 2007): um ensaio sobre a aplicação do regime urbanistico do PDDUA em uma área da cidade. Monography, 12p. Institute of Geosciences. Federal University of Rio Grande do Sul, Porto Alegre, Brazil.

PIACENTINI, R.; SALUM, G.; DUBBELING, M. El cambio climático, su impacto y las posibles formas de mitigación y adaptación. Bogota, 2016. Universidad del Externado. 51p.

PICKETT, S.TA; CADENASSO, Mary L.; GROVE, J. Morgan. Resilient cities: meaning, models, and metaphor for integrating the ecological, socio-economic, and planning realms. Landscape and urban Planning, 2004, vol. 69, no 4, p. 369-384

PIRES DE OLIVEIRA, Alusio, et al. Estatuto da cidade: Anotações à Lei 10.257, de 10.07.2001. Curitiba: Juruá editora, 2004. 77 p.

RITCHIE, A., THOMAS, R. Sustainable urban design: an environmental approach. Taylor \& Francis, 2013.

SECRETARIA DISTRITAL AMBIENTAL. Inventario de Gases Efecto Invernadero 2008. Disponivel em http://www.ambientebogota.gov.co/web/sda/cambio-climatico. Acesso Dezembro 2016

SECRETARÍA DISTRITAL DE PLANEACIÓN, SDP. Primera encuesta multipropósito para Bogotá. Alcaldía Mayor de Bogotá. Bogotá, 2011.

SIEBERT, C.A.F. Mudanças climáticas e resiliência urbana. Anais: Encontros Nacionais da ANPUR, p. 1-18, 15 (2013)

SUAREZ, M. A RESILIÊNCIA DOS ECOSSISTEMAS URBANOS: Uma proposta de avaliação para a sustentabilidade. Madrid, 2012. 41p. Tese final do Mestrado-Mestrado Universitario em Ecologia, Universidade Autônoma e Complutense de Madrid. 
SUZUKI, H., CERVERO, R., IUCH, K. Transformando las ciudades con el transporte público. Integración del transporte público y el uso del suelo para un desarrollo urbano sostenible. Bogotá, Editorial Kimpres. 2014

TIDBALL, K. G., \& KRASNY, M. E. (2007). From risk to resilience: What role for community greening and civic ecology in cities. Social learning towards a more sustainable world, 149-164.

TUROK, I. (2014) 'Cities as drivers of development' in S. KayizzaMugerwa, A. Shimeles and N. D. Yameogo(eds)Urbanization and Socioeconomic Development in Africa: Challenges and Opportunities, Routeledge, London

UNEP (United Nations Environment Program). Global Environment Outlook 3: Past, Present and Future Perspectives. Nairobi: UNEP; London: Earthscan, 2002.

UNEP, 2007. Global Environment Outlook GEO4. Valletta, Malta, 2007. $87 p$.

UN-HABITAT, 2007. Enhacing urban safety and security. Global report on human settlements 2007.London, UK.

UN-HABITAT, 2011. Cities and Climate Change. Global report on human settlements 2011. London, UK. $5 p$.

UN-HABITAT. GLOBAL ACTIVITIES REPORT 2015. Increasing Synergy for Greater National Ownership. Nairobi, Kenya. 2015.

UN-HABITAT, 2016. Urbanization and development: Emerging futures. World cities report 2016. United Nations Human Settlements Programme (UN-Habitat) Nairobi, Kenya.

URWIN, K.; JORDAN, A. Does public policy support or undermine climate change adaptation? Exploring policy interplay across different scales of governance. Norwich, 2007. 12p. Tyndall Centre for Climate Change Research, School of Environmental Sciences, University of East Anglia.

VEYRET, Y. (Org.) Os riscos: o homem como agressor e vítima do meio ambiente. São Paulo: Contexto, 2007. p. 23-79.

WALKER, B., SALT, D. Resilience thinking: sustaining ecosystems and people in a changing world. Island Press, 2012.

WAMSLER, C.; BRINK, E.; RIVERA, C. Planning for climate change in urban áreas: from theory to practice. Lund, Sweden, 2012. 14p. Lund University Centre for Sustainability Studies. 
WILSON, G. Community resilience, policy corridors and the policy challenge. Plymouth UK, 2012. 13p. School of Geography, Earth and Environmental Sciences, University of Plymouth.

WORLD RESOURCES INSTITUTE, Millennium Ecosystem Assessment Ecosystems and Human Well Being, (2005) Millennium Ecosystem Assessment, Island Press, Washington, DC 


\section{9 \\ Apêndices}

APÊNDICE A - MATRIZ DE ANÁLISE DE CONTRIBUICAO

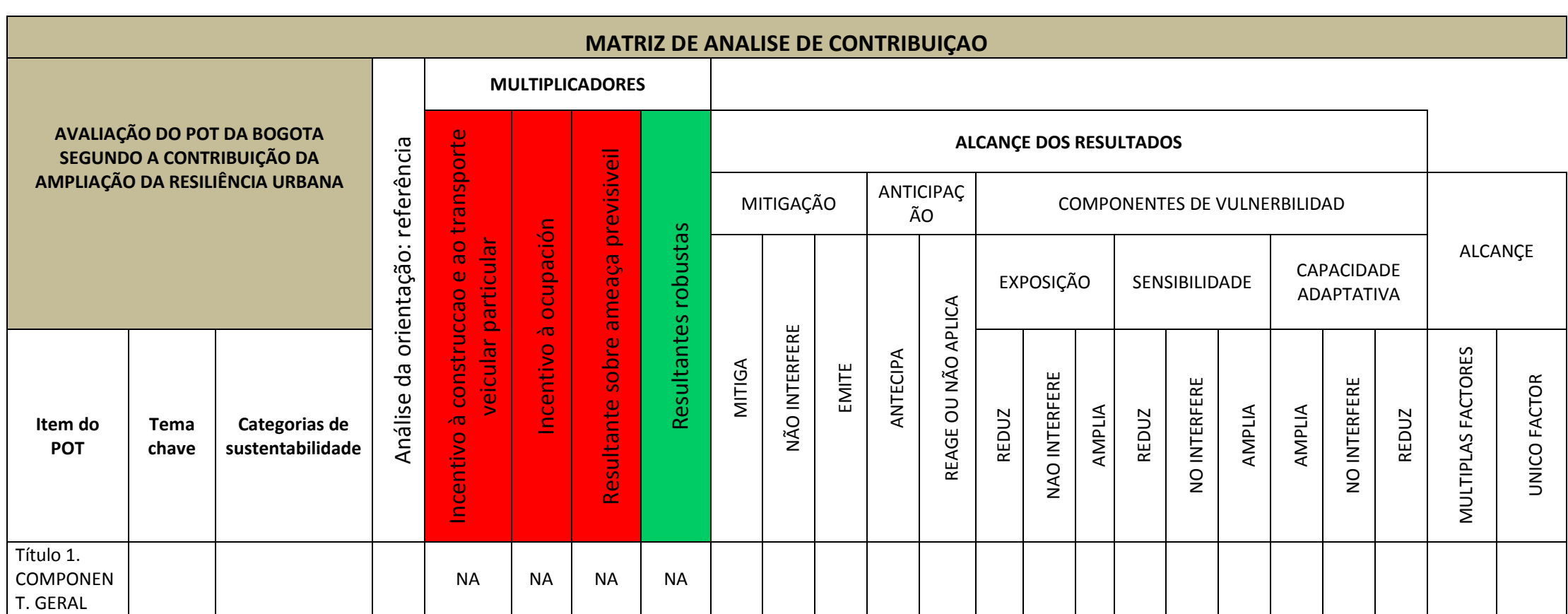

